Argonne

\title{
Radiological Dose and Risk Assessment of Landfill Disposal of Technologically Enhanced Naturally Occurring Radioactive Materials (TENORM) in North Dakota
}

Environmental Science Division 


\begin{abstract}
About Argonne National Laboratory
Argonne is a U.S. Department of Energy laboratory managed by UChicago Argonne, LLC under contract DE-AC02-06CH11357. The Laboratory's main facility is outside Chicago, at 9700 South Cass Avenue, Argonne, Illinois 60439. For information about Argonne and its pioneering science and technology programs, see www.anl.gov.
\end{abstract}

\title{
DOCUMENT AVAILABILITY
}

Online Access: U.S. Department of Energy (DOE) reports produced after 1991 and a growing number of pre-1991 documents are available free via DOE's SciTech Connect (http://www.osti.gov/scitech/).

Reports not in digital format may be purchased by the public from the National Technical Information Service (NTIS):

U.S. Department of Commerce

National Technical Information Service

5301 Shawnee Rd

Alexandria, VA 22312

www.ntis.gov

Phone: (800) 553-NTIS (6847) or (703) 605-6000

Fax: (703) 605-6900

Email: orders@ntis.gov

Reports not in digital format are available to DOE and DOE contractors from the Office of Scientific and Technical Information (OSTI):

U.S. Department of Energy

Office of Scientific and Technical Information

P.O. Box 62

Oak Ridge, TN 37831-0062

www.osti.gov

Phone: (865) 576-8401

Fax: (865) 576-5728

Email: reports@osti.gov

\section{Disclaimer}

This report was prepared as an account of work sponsored by an agency of the United States Government. Neither the United States Government nor any agency thereof, nor UChicago Argonne, LLC, nor any of their employees or officers, makes any warranty, express or implied, or assumes any legal liability or responsibility for the accuracy, completeness, or usefulness of any information, apparatus, product, or process disclosed, or represents that its use would not infringe privately owned rights. Reference herein to any specific commercial product, process, or service by trade name, trademark, manufacturer, or otherwise, does not necessarily constitute or imply its endorsement, recommendation, or favoring by the United States Government or any agency thereof. The views and opinions of document authors expressed herein do not necessarily state or reflect those of the United States Covernment or any agency thereof, Argonne National Laboratory, or UChicago Argonne, LLC. 


\section{Radiological Dose and Risk Assessment of Landfill Disposal of Technologically Enhanced Naturally Occurring Radioactive Materials (TENORM) in North Dakota}

prepared by

Christopher B. Harto, Karen P. Smith, Sunita Kamboj, and John J. Quinn

Environmental Science Division, Argonne National Laboratory

November 2014 



\section{CONTENTS}

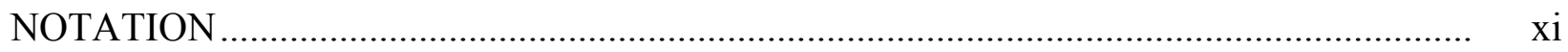

ENGLISH/METRIC AND METRIC/ENGLISH EQUIVALENTS ............................... xiv

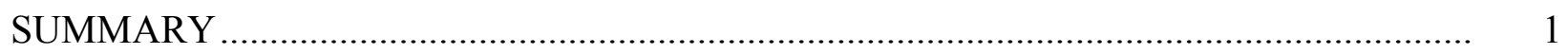

1 INTRODUCTION ........................................................................................ 5

2 TENORM WASTE STREAMS ….................................................................... 7

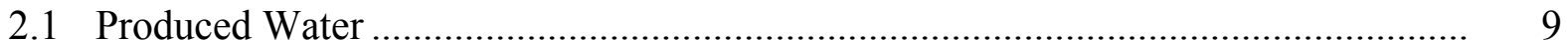

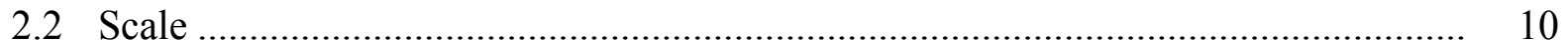

2.3 Sludge and Filter Cake ................................................................................ 10

2.4 Filter Socks .......................................................................................... 10

2.5 Lead-210 Deposits in Gas Equipment ................................................................ 10

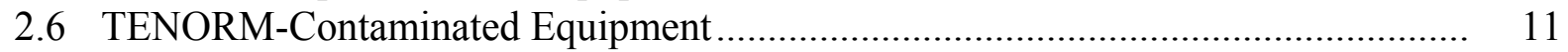

2.7 TENORM-Contaminated Soils ................................................................. 11

2.8 Synthetic Fracturing Proppant ....................................................................... 11

3 LANDFILL DISPOSAL AND POTENTIAL EXPOSURE SCENARIOS .................... 13

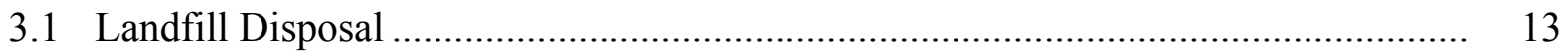

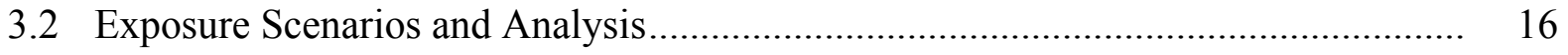

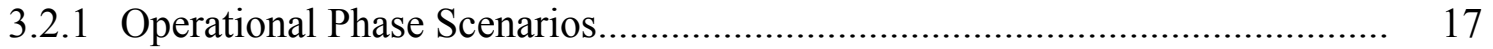

3.2.1.1 Well Site Operations Scenarios................................................... 17

3.2.1.2 Transportation Scenarios.......................................................... 19

3.2.1.3 Landfill Operations Scenarios.................................................... 19

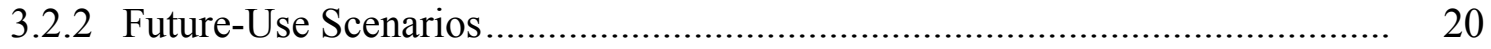

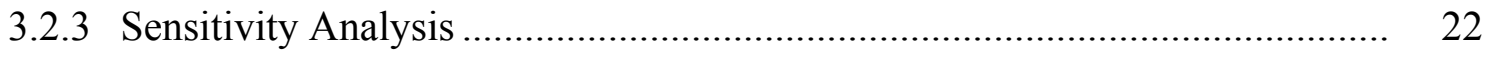

4 MODELING METHODOLOGIES ................................................................ 23

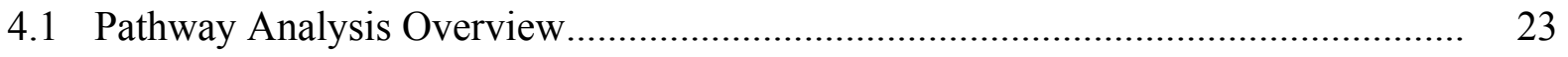

4.2 Description of Risk Assessment Methodology ................................................... 25

4.2.1 Methodology for Operational Phase Scenarios ...................................... 25

4.2.1.1 Well Site Operations ............................................................... 25

4.2.1.2 Transportation ......................................................................... 25

4.2.1.3 Landfill Operations .............................................................. 26

4.2.2 Methodology for Future-Use Scenarios................................................. 26

4.2.3 Calculating Maximum Allowable TENORM Concentrations for Landfill

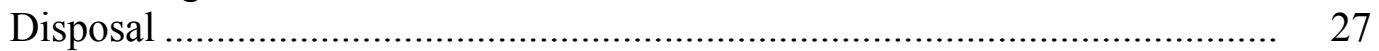

4.3 Hydrologic Modeling ........................................................................................ 27

4.3.1 Landfill Hydrologic Modeling .......................................................... 28 


\section{CONTENTS (Cont.)}

4.3.2 Hydrogeological Setting of a Generic Landfill and Model Parameter

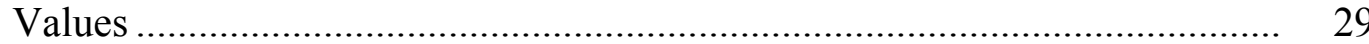

4.3.3 Unsaturated Zone Modeling ............................................................... 30

4.3.4 Groundwater Transport Modeling ........................................................ 30

4.3.4.1 The Distribution Coefficient and Retardation.............................. 30

4.3.4.2 Dispersivity ........................................................................... 32

4.3.4.3 Groundwater Flow and Contaminant Transport Code Selection ...... 32

5 HYDROLOGICAL MODELING RESULTS ........................................................

5.1 Landfill Hydrologic Modeling ............................................................................ 35

5.2 Unsaturated Zone Flow and Transport ............................................................... 41

5.3 Saturated Zone Flow and Transport ................................................................... 41

5.4 Discussion of Results ......................................................................................... 44

6 DOSE AND RISK ASSESSMENT RESULTS ….................................................... 47

6.1 Well Site Operational Phase Scenarios ............................................................ 47

6.1.1 Radiological Doses for Well Site Workers................................................ 47

6.1.2 Parameter Sensitivity Analyses for Well Site Operation Scenarios .............. 49

6.2 Radiological Dose from Accidental Public Exposure Scenarios ........................... 52

6.3 Future-Use Scenarios.................................................................................. 54

6.3.1 Calculated Radiological Dose to Source Ratio for Future-Use Scenarios ...... 54

6.3.2 Results of Analysis for Different Radionuclides .................................... 56

6.3.3 Estimated Allowable Concentrations in the Landfill.................................. 56

6.3.4 Parameter Sensitivity Analyses for Future-Use Scenarios .......................... 56

6.4 Radiological Dose and Risk from Transportation ............................................. 58

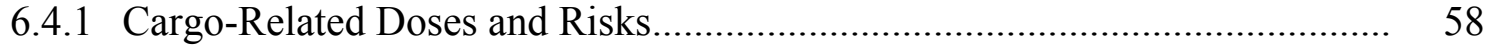

6.4.2 Vehicle-Related Risks ......................................................................... 60

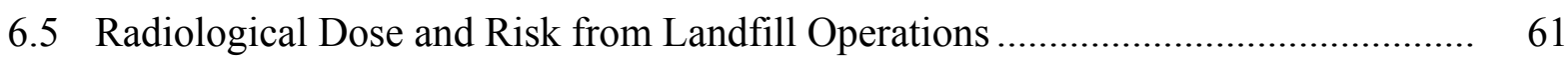

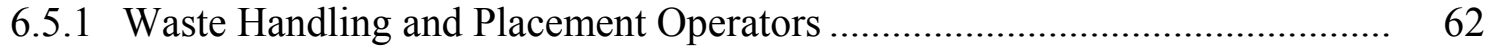

6.5.2 General Public Exposures Due to Landfill Operations................................. 63

6.5.3 Leachate Management Workers ............................................................ 63

6.5.4 Parameter Sensitivity Analyses for Landfill Operation Scenarios ................ 64

6.6 Summary of Dose and Risk Assessment Results ................................................ 65

6.7 Calculating the Maximum Allowable Radium Concentration for TENORM Disposal in Landfills in North Dakota..................................................................... 67

7 CONCLUSIONS AND RECOMMENDATIONS ...............................................

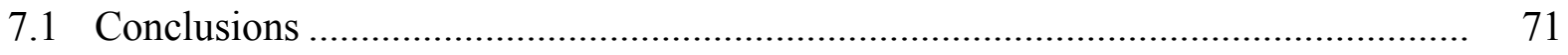

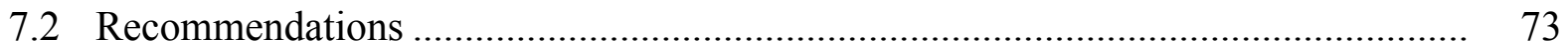




\section{CONTENTS (Cont.)}

8 REFERENCES

APPENDIX A: Radionuclide Analysis Data for TENORM Waste Samples Collected in North Dakota.

APPENDIX B: Risk Assessment Data Tables

APPENDIX C: Landfill Designs Tested with the HELP Model

C-1

APPENDIX D: Literature Review of the Distribution Coefficient $\mathrm{K}_{\mathrm{d}}$

D-1

APPENDIX E: Groundwater Calculations

E-1

\section{FIGURES}

2.1 Histogram Illustrating the Distribution of the Ratio of Th-232 to Total Radium Activity Concentrations from All Samples Where Th-232 Was Measured

3.1 Special Waste Landfills Permitted in North Dakota

4.1 Typical Radiation Exposure Levels for Common Activities

5.1 HELP Model Results for the Closed Industrial Waste Landfill for Precipitation, Evapotranspiration, and Runoff over 100 Years.

5.2 HELP Model Results for the Closed Industrial Waste Landfill for Percolation through the Compacted Soil of the Cap and through the Upper Geomembrane Liner over 100 Years

5.3 HELP Model Results for the Closed Industrial Waste Landfill for Percolation through the Recompacted Liner Soil and the Deep Natural Soil over 100 Years

5.4 HELP Model Results for the Closed Industrial Waste Landfill with Decomposed Geomembranes and an Inactive LCS for Percolation through the Cover's Barrier Soil, the Recompacted Liner Soil, and the Deep Natural Soil over 100 Years

5.5 Hydraulic Heads, Landfill Location, and Receptor Locations at the Upgradient End of the Modeling Domain

5.6 Base Case Results for C/Co at 100 m over 10,000 Years for Each of the ROCs Modeled. 


\section{FIGURES (Cont.)}

6.1 Steps Involved in Estimating the Allowable Concentration in the Landfill from Future-Use Scenarios

6.2 Worker Dose for Receiving and Handling TENORM Wastes at the Landfill

6.3 Worker Dose for Waste-Placement Activities at the Landfill

D.1 Relationship between $\mathrm{K}_{\mathrm{d}}$ and Leached Fraction of Ra-226 Samples

D-5

\section{TABLES}

2.1 North Dakota TENORM Waste Characterization Data

3.1 Large Volume Industrial Waste Landfill and Special Waste Landfills Permitted in North Dakota in 2013

4.1 Values Used To Model Radionuclide Concentrations in the Groundwater Downgradient of a Landfill.

5.1 Summary of HELP-Model-Derived Percolation Results for Industrial and Special Waste Landfill Scenarios

5.2 Half-life and Rate Constant Values for Radionuclides of Concern

5.3 Maximum Ratio of Downgradient Groundwater Concentration to Leachate Recharge Concentration over 10,000 Years

6.1 Waste Streams Used in Evaluating Radiation Dose in Different Worker and Public Scenarios from Well Site Operations

6.2 Estimated Maximum Dose Rate for Different Well Site Operations Using Average Radionuclide Concentration

6.3 Estimated Maximum Dose Rate for Different Well Site Operations Using Maximum Radionuclide Concentration.

6.4 Sensitivity Analyses for Well Site Operations Assuming Average Radionuclide Concentrations in the TENORM Wastes

6.5 PPE Sensitivity Analysis Results for Well Site Operation Worker Scenarios 


\section{TABLES (Cont.)}

6.6 Estimated Dose Rates for Maximum and Average Concentrations at Different Times for a Child Using Filter Socks as a Toy

6.7 Estimated Dose Rates for Maximum and Average Concentrations at Different

Times for a City Dweller Exposed to Filter Socks in a Dumpster.

6.8 Estimated Dose Rate for Maximum and Average Concentrations at Different Times for Proppant Used at a Playground

6.9 Summary Results for Dose to Source Ratio

6.10 Limiting Average Concentration Based on Future-Use Scenarios and Allowable TENORM Concentrations at the 100-mrem/yr Dose Limit Assuming a

Two Meter-Thick Cover

6.11 Limiting Average Landfill Concentration and Limiting Scenario with Maximum

DSR by Radionuclide

6.12 Cargo-Related Transportation Doses and Risks for Base Case and Maximum Case

Conditions, Assuming a Transportation Distance of $250 \mathrm{~km}$.

6.13 Vehicle-Related Transportation Risks for Base Case and Maximum Case Conditions, Assuming a Round-Trip Transportation Distance of $500 \mathrm{~km}$

6.14 Radiological Dose Associated with Landfill Disposal of TENORM under the Base Case Scenario

6.15 Allowable Total Radionuclide Activity and the Resultant Allowable TENORM Concentration at the 100-mrem/yr Dose Limit

6.16 Estimated Dose Rate from Evaporation Pond Operations

6.17 Estimated Allowable TENORM Concentrations Based on Future-Use Scenarios and Landfill Worker Scenarios

6.18 Allowable Radionuclide Concentrations in the Waste Stream Disposed of at the Landfill Based on Different Radionuclide Concentration Fractions in the Waste Stream

A.1 Radionuclide Analysis Data for TENORM Waste Samples Collected in North Dakota.

B.1 RESRAD-BUILD Input Parameters Describing Well Site Operations.. 


\section{TABLES (Cont.)}

B.2 Input Parameters Describing Public Exposures to the Unauthorized Release of Filter Socks and Proppants.

B.3 TSD-DOSE Input Parameters Describing Landfill Worker Operations for Disposing of Containerized Waste.

B.4 TSD-DOSE Input Parameters Describing Landfill Worker Operations for Disposing of Bulk Waste.

B.5 RESRAD-BUILD Input Parameters Describing Evaporation Pond Worker

Operations

B.6 Parameters Describing the Landfill Future-Use Scenarios

B.7 Parameters Used for the Transportation Risk Assessment

B.8 Conditional Accident Probabilities and Associated Release Fraction by Accident Severity Category

C.1 Special Waste Landfill Design........................................................................... C-3

C.2 Industrial Waste Landfill Design .......................................................................... C-4

D.1 Ra-226 Leached Fraction and $\mathrm{K}_{\mathrm{d}}$ of Samples Containing Ra-226 ........................... D-4

E.1 Calculations Relating Disposal Concentration of Unity, Appropriate Range of In-Landfill $\mathrm{K}_{\mathrm{d}}$ Values, Leachate Concentration Reaching Water Table, Downgradient Proportion of Leachate Recharge, and Concentration in Groundwater for 100-m Downgradient Receptor and 20-m Thick Unsaturated Zone

E.2 Calculations Relating Disposal Concentration of Unity, Appropriate Range of In-Landfill $\mathrm{K}_{\mathrm{d}}$ Values, Leachate Concentration Reaching Water Table, Downgradient Proportion of Leachate Recharge, and Concentration in Groundwater for 100-m Downgradient Receptor and 5-m Thick Unsaturated Zone... E-4

E.3 Calculations Relating Disposal Concentration of Unity, Appropriate Range of In-Landfill $\mathrm{K}_{\mathrm{d}}$ Values, Leachate Concentration Reaching Water Table, Downgradient Proportion of Leachate Recharge, and Concentration in Groundwater for 300-m Downgradient Receptor and 20-m Thick Unsaturated Zone 


\section{TABLES (Cont.)}

E.4 Calculations Relating Disposal Concentration of Unity, Appropriate Range of In-Landfill $\mathrm{K}_{\mathrm{d}}$ Values, Leachate Concentration Reaching Water Table, Downgradient Proportion of Leachate Recharge and Concentration in Groundwater for 300-m Downgradient Receptor and 5-m Thick Unsaturated Zone ... E-6 
This page intentionally left blank. 


\section{NOTATION}

The following is a list of the acronyms, initialisms, and abbreviations (including units of measure) used in this document.

\section{ACRONYMS, INITIALISMS, AND ABBREVIATIONS}

A\&A Auxier and Associates, Inc.

Barr Barr Engineering

CEDE committed effective dose equivalent

DOE U.S. Department of Energy

DSR dose to source ratio

EDE effective dose equivalent

EPA U.S. Environmental Protection Agency

Golder Golder Associates

HDPE high-density polyethylene

HELP Hydrologic Evaluation of Landfill Performance

ICRP International Commission on Radiological Protection

K hydraulic conductivity

$\mathrm{K}_{\mathrm{d}} \quad$ distribution coefficient

LCF latent cancer fatality

LCS leachate collection system

LF leached fraction

LLW low-level radioactive waste

MEI maximally exposed individual

MODFLOW Modular Three-Dimensional Finite-Difference Groundwater Flow Model

MT3DMS Modular 3-D Multi-Species Transport Model

NCRP National Council on Radiation Protection and Measurements

NDAC North Dakota Administrative Code

NDDH North Dakota Department of Health

NDDOT North Dakota Department of Transportation

NORM naturally occurring radioactive material(s)

NRC U.S. Nuclear Regulatory Commission 


$\begin{array}{ll}\text { PPE } & \text { personal protective equipment } \\ \text { ROC } & \text { radionuclide of concern } \\ \text { SD } & \text { standard deviation } \\ \text { TCLP } & \begin{array}{l}\text { toxicity characteristic leaching procedure } \\ \text { total effective dose equivalent }\end{array} \\ \text { TENORM } & \begin{array}{l}\text { technologically enhanced naturally occurring radioactive material } \\ \text { treatment, storage, and disposal }\end{array} \\ \text { TSD } & \text { Wenck Associates, Inc. }\end{array}$

\section{RADIONUCLIDES}

\begin{tabular}{|c|c|}
\hline $\mathrm{Pb}-210$ & lead-210 \\
\hline Ra-226 & radium-226 \\
\hline Ra-228 & radium-228 \\
\hline Rn-222 & radon-222 \\
\hline Th-232 & thorium-232 \\
\hline U-238 & uranium-238 \\
\hline
\end{tabular}

\section{UNITS OF MEASURE}

$\begin{array}{ll}\begin{array}{ll}\mathrm{cm} \\ \mathrm{cm}^{2} \\ \mathrm{~cm}^{3}\end{array} & \begin{array}{l}\text { centimeter(s) } \\ \text { square centimeter(s) } \\ \text { cubic centimeter(s) }\end{array} \\ \mathrm{d} & \text { day(s) } \\ \mathrm{ft} & \begin{array}{l}\text { foot (feet) } \\ \text { square foot (feet) } \\ \mathrm{ft}^{2}\end{array} \\ \mathrm{ft}^{3} & \text { cubic foot (feet) } \\ \mathrm{g} & \text { gram(s) } \\ \mathrm{gal} & \text { gallon(s) } \\ \mathrm{h} & \text { hour(s) } \\ \text { ha } & \text { hectare(s) } \\ \text { in. } & \text { inch(es) }\end{array}$




$\begin{array}{ll}\mathrm{kg} & \text { kilogram(s) } \\ \mathrm{km} & \text { kilometer(s) } \\ \mathrm{km}^{2} & \text { square kilometer(s) } \\ \mathrm{L} & \text { liter(s) } \\ \mathrm{L}^{3} & \text { cubic liter(s) } \\ \mathrm{lb} & \text { pound(s) } \\ \mathrm{m} & \text { meter(s) } \\ \mathrm{M} & \text { mass } \\ \mathrm{m}^{2} & \text { square meter(s) } \\ \mathrm{m}^{3} & \text { cubic meter(s) } \\ \mathrm{mg} & \text { milligram(s) } \\ \mathrm{mi} & \text { mile(s) } \\ \mathrm{mi} & \text { square mile(s) } \\ \mathrm{mil} & \text { one thousandth of an inch }(0.0254 \text { millimeter) } \\ \mathrm{mL} & \text { milliliter(s) } \\ \mathrm{mm} & \text { millimeter(s) } \\ \mathrm{mph} & \text { mile(s) per hour } \\ \mathrm{mrem} & \text { millirem(s) } \\ \mathrm{pCi} & \text { picocurie(s) } \\ \mathrm{rem} & \text { roentgen equivalent man } \\ \mu \mathrm{R} & \text { micro-roentgen } \\ \mathrm{s} & \text { second(s) } \\ \mathrm{yd} & \text { cubic yard(s) } \\ \mathrm{yr} & \text { year(s) } \\ & \end{array}$




\section{ENGLISH/METRIC AND METRIC/ENGLISH EQUIVALENTS}

The following table lists the appropriate equivalents for English and metric units.

\begin{tabular}{|c|c|c|}
\hline Multiply & By & To Obtain \\
\hline 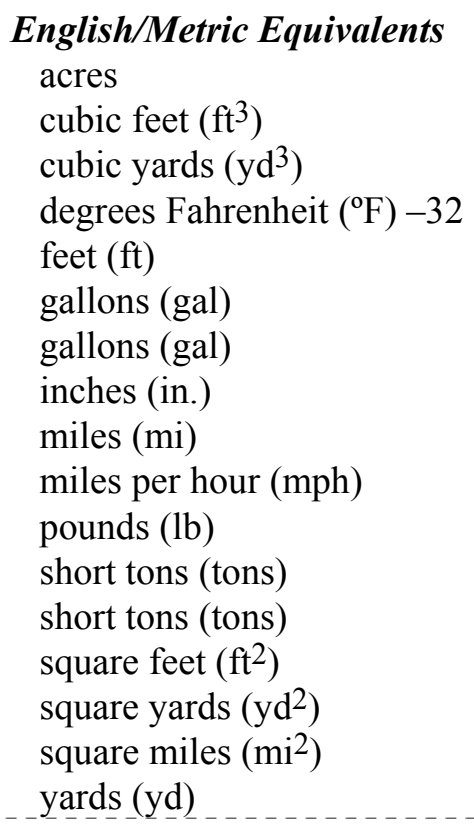 & $\begin{array}{l}\quad 0.4047 \\
0.02832 \\
0.7646 \\
0.5555 \\
0.3048 \\
3.785 \\
0.003785 \\
2.540 \\
1.609 \\
1.609 \\
0.4536 \\
907.2 \\
0.9072 \\
0.09290 \\
0.8361 \\
2.590 \\
0.9144 \\
-.-1\end{array}$ & 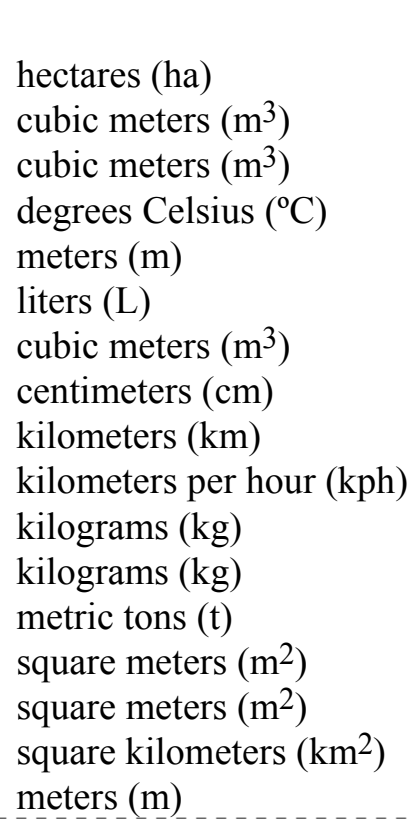 \\
\hline $\begin{array}{l}\text { Metric/English Equivalents } \\
\text { centimeters }\left(\mathrm{cm}^{2}\right) \\
\text { cubic meters }\left(\mathrm{m}^{3}\right) \\
\text { cubic meters }\left(\mathrm{m}^{3}\right) \\
\text { cubic meters }\left(\mathrm{m}^{3}\right) \\
\text { degrees Celsius }\left({ }^{\circ} \mathrm{C}\right)+17.78 \\
\text { hectares }(\mathrm{ha}) \\
\text { kilograms }(\mathrm{kg}) \\
\text { kilograms }(\mathrm{kg}) \\
\text { kilometers }(\mathrm{km}) \\
\text { kilometers per hour }(\mathrm{kph}) \\
\text { liters }(\mathrm{L}) \\
\text { meters }(\mathrm{m}) \\
\text { meters }(\mathrm{m}) \\
\text { metric tons }(\mathrm{t}) \\
\text { square kilometers }\left(\mathrm{km}^{2}\right) \\
\text { square meters }\left(\mathrm{m}^{2}\right) \\
\text { square meters }\left(\mathrm{m}^{2}\right)\end{array}$ & $\begin{array}{l}0.3937 \\
35.31 \\
1.308 \\
264.2 \\
1.8 \\
2.471 \\
2.205 \\
0.001102 \\
0.6214 \\
0.6214 \\
0.2642 \\
3.281 \\
1.094 \\
1.102 \\
0.3861 \\
10.76 \\
1.196\end{array}$ & $\begin{array}{l}\text { inches (in.) } \\
\text { cubic feet }\left(\mathrm{ft}^{3}\right) \\
\text { cubic yards }\left(\mathrm{yd}^{3}\right) \\
\text { gallons (gal) } \\
\text { degrees Fahrenheit }\left({ }^{\circ} \mathrm{F}\right) \\
\text { acres } \\
\text { pounds (lb) } \\
\text { short tons (tons) } \\
\text { miles (mi) } \\
\text { miles per hour (mph) } \\
\text { gallons (gal) } \\
\text { feet (ft) } \\
\text { yards (yd) } \\
\text { short tons (tons) } \\
\text { square miles }\left(\mathrm{mi}^{2}\right) \\
\text { square feet }\left(\mathrm{ft}^{2}\right) \\
\text { square yards }\left(\mathrm{yd}^{2}\right)\end{array}$ \\
\hline
\end{tabular}




\title{
RADIOLOGICAL DOSE AND RISK ASSESSMENT OF LANDFILL DISPOSAL OF TECHNOLOGICALLY ENHANCED NATURALLY OCCURRING RADIOACTIVE MATERIALS (TENORM) IN NORTH DAKOTA
}

\author{
by
}

\author{
Christopher B. Harto, Karen P. Smith, Sunita Kamboj, and John J. Quinn
}

\section{SUMMARY}

Some of the waste streams generated by the oil and gas sector in North Dakota contain naturally occurring radioactive materials (NORM) in concentrations above background. In North Dakota, these materials are referred to as technologically enhanced NORM (TENORM). If these wastes are not properly managed, they can potentially present unacceptably high human health risks. The North Dakota Department of Health (NDDH) is considering possible changes to North Dakota Radiologic Health Rules and Solid Waste Management Rules regarding TENORM. The NDDH is taking steps to ensure that any possible rule changes regarding handling and disposal of TENORM are protective of human health and the environment. Argonne National Laboratory (Argonne) has conducted a radiological dose and risk assessment of the disposal of TENORM wastes in permitted Industrial Waste and Special Waste Landfills in North Dakota.

The risk assessment evaluated the radiological doses associated with a number of scenarios associated with oil and gas well site operations, improperly managed wastes, transportation of TENORM, and disposal of TENORM in Industrial Waste and Special Waste Landfills permitted in North Dakota. Limited characterization data are available for most of the TENORM waste streams generated in North Dakota by oil and gas operations. The study was designed to minimize its reliance upon specific waste characterization data. For the well site worker and public accidental exposure scenarios, potential doses were calculated on the basis of both the average and maximum radionuclide concentrations for specific waste types relevant to the scenario, the latter providing conservatively high dose estimates. For the landfill worker and future use-scenarios, the study was designed to calculate the maximum allowable radionuclide concentrations that could be present in landfilled wastes such that potential doses would not exceed the 100-mrem/yr dose limit recommended for members of the general public by the International Commission on Radiological Protection (ICRP).

The primary TENORM waste streams of concern from oil and gas wells in North Dakota include scale accumulated within pipe and other oilfield equipment, sludge accumulated in produced water storage tanks and vessels, filter cake from filtration of water, disposable filter socks, and some synthetic fracturing proppants that have been found to contain low levels of TENORM. These wastes were found to contain elevated levels of the radionuclides radium-226 (Ra-226), radium-228 (Ra-228), lead-210 (Pb-210), and thorium-232 (Th-232). A total of 119 waste samples were analyzed by the NDDH, although not all radionuclides were measured for all samples (more details on the waste characterization can be found in Section 2 and 
Appendix A). Many previous TENORM risk assessment studies did not include thorium because of the lack of data. In addition, state regulations for TENORM and NORM disposal typically impose limits based upon total radium (Ra-226 plus Ra-228) activity concentrations. This study recommends similar limits, taking into consideration the presence of Th-232 and the relative concentrations of Th-232 and total radium in the waste samples measured.

Pathway analysis computer codes were used to estimate doses for both workers and members of the general public. These codes included the RESRAD-BUILD, RADTRAN, TSD-DOSE, and RESRAD. A wide range of exposure scenarios were evaluated. The risks associated with a number of specific well site operations were estimated, including mixing hydraulic fracturing fluid, produced water filtration, pipe cleaning, storage tank cleaning, equipment cleaning at a gas processing plant, and sludge treatment. In all scenarios except the produced water filtration scenario, it was assumed that workers were equipped with personal protective equipment (PPE) (e.g., respirators, eye protection, and gloves). The maximum dose calculated, assuming average waste activity concentrations, was $20 \mathrm{mrem} / \mathrm{yr}$ for the worker involved in mixing hydraulic fracturing fluid. However, when maximum radionuclide concentrations were assumed, the dose for workers engaged in pipe cleaning was $130 \mathrm{mrem} / \mathrm{yr}$, and the dose for storage tank cleaners was $70 \mathrm{mrem} / \mathrm{yr}$. When the sensitivity analyses were run, assuming workers were not equipped with PPE, the estimated dose for a number of the scenarios approached or exceeded the $100 \mathrm{mrem} / \mathrm{yr}$ level. These results suggest that it may be important to monitor and limit the duration of exposure for workers involved in pipe and storage tank cleaning activities and that the use of proper PPE is important to protect workers with regular exposure to TENORM.

Risk to the public from improper waste disposal was estimated for three scenarios. The first involved a child playing with a used filter sock, the second involved a load of filter socks being disposed of in an urban dumpster, and the third involved a child playing in a pile of spilled synthetic proppants. The maximum dose calculated, assuming maximum radionuclide concentrations, was $4.9 \mathrm{mrem} / \mathrm{yr}$ for the individual exposed to the filter socks disposed of in an urban dumpster. When average concentrations were assumed, the estimated dose dropped below $1 \mathrm{mrem} / \mathrm{yr}$. Assuming maximum concentrations, the dose for a child playing with a used filter sock was less than $1 \mathrm{mrem} / \mathrm{yr}$, while the dose for a child playing in a field where proppants were illegally dumped was less than $2 \mathrm{mrem} / \mathrm{yr}$. While these few scenarios seem to indicate that the risks to the public are likely relatively low from short-term exposure to waste that is improperly disposed of, they are not representative of all possible exposures. Extra care should be taken to ensure that such exposures do not occur.

The routine cargo-related doses and risks from transportation were estimated for a truck driver and an individual living near the landfill. The maximum doses to drivers and to any member of the public were found to be about $20 \mathrm{mrem} / \mathrm{yr}$ and $3.2 \times 10^{-6} \mathrm{mrem} / \mathrm{yr}$, respectively. Since these doses are quite small compared with the 100-mrem/yr recommended dose limit, the transportation of TENORM does not appear to be a major consideration in possible rule changes regarding TENORM disposal. Moreover, the maximum collective doses to persons living along and sharing the transportation corridor for routine and accident conditions were $1.3 \times 10^{-4}$ person-rem/yr and 7.2 person-rem/yr, respectively. It should be noted that the risk of 
getting involved in a fatal transportation accident is at least 100 times greater than that of the driver contracting a latent fatal cancer associated with the TENORM shipment.

Landfill disposal scenarios considered both worker and public exposures during operation of the landfill, as well as possible exposures to future users of the land post-closure. Exposure to landfill workers involved with receiving and handling waste, transporting waste within the landfill, and waste placement were all analyzed. Five future-use scenarios were also evaluated: (1) a residential-use scenario, in which a resident is assumed to construct a house on top of the landfill, use the surrounding area for growing crops, and obtain drinking and irrigation water from an on-site well; (2) an industrial-use scenario, in which the land encompassing the landfill is used for industrial purposes; (3) a recreational-use scenario, in which the landfill is turned into a recreational area; (4) an intruder scenario, in which a resident on the landfill site accidentally uncovers the buried wastes and disperses the material around his or her property; and (5) an offsite groundwater-use scenario, in which an off-site resident obtains water from a well drilled downgradient of the landfill. For the groundwater-use scenario, infiltration and percolation rates were modeled using the Hydrologic Evaluation of Landfill Performance (HELP) model. Groundwater flow and contaminant transport were modeled using the Modular Three-Dimensional Finite-Difference Groundwater Flow Model (MODFLOW) and the Modular 3-D Multi-Species Transport Model (MT3DMS).

For landfill disposal, the analyses were run to calculate the maximum average waste activity concentration for each radionuclide that could be disposed of in the landfill while ensuring that potential doses to all receptors did not exceed $100 \mathrm{mrem} / \mathrm{yr}$ during either landfill operations or during future use of the landfill property. The results showed that potential exposures to landfill workers are more restrictive than potential exposures related to future use of the landfill, in terms of the maximum TENORM concentrations that can be disposed of in the landfill safely. The workers involved in receiving and handling or waste placement activities received the highest estimated dose. Decreasing the volume of TENORM wastes that can be disposed of per year in a single landfill could effectively reduce doses to all landfill workers. Alternatively, potential doses could be reduced by limiting the number of hours that workers are exposed to the TENORM wastes.

On the basis of the hydrologic modeling and the dose assessment results, disposal of TENORM wastes in both Industrial Landfills and Special Waste Landfills is appropriate provided restrictions are placed on the average waste activity concentration, waste volumes disposed per year, and the depth of the TENORM wastes within the landfill. North Dakota regulations may be modified to allow TENORM wastes containing an average concentration of less than or equal to $50 \mathrm{pCi} / \mathrm{g}$ of total radium (independent of background radium levels) to be disposed of in either Industrial Landfills or Special Wastes Landfills, provided the following conditions are met:

- No more than 25,000 tons of TENORM wastes are disposed of in a single landfill per year. 
- The average thorium activity concentration in the waste does not exceed $24 \mathrm{pCi} / \mathrm{g}$. (This concentration assumes a thorium to radium ratio of $49 \%$ at $50 \mathrm{pCi} / \mathrm{g}$ total radium.)

- TENORM wastes must be covered by at least $2 \mathrm{~m}(6 \mathrm{ft})$ of a combination of the landfill cover materials and clean wastes that do not contain radionuclides. 


\section{INTRODUCTION}

Some of the waste streams generated by the oil and gas sector in North Dakota contain naturally occurring radioactive materials (NORM) in concentrations above natural background levels of radionuclides. In North Dakota, these materials are referred to as technologically enhanced NORM (TENORM). If these wastes are not properly managed, they can potentially present unacceptably high human health risks. The international petroleum industry uses a variety of methods to ensure the safe management and disposal of these wastes. The North Dakota Department of Health (NDDH) is considering possible changes to North Dakota Radiologic Health Rules and Solid Waste Management Rules regarding TENORM. The NDDH is taking steps to ensure that any possible rule changes regarding handling and disposal of TENORM are protective of human health and the environment. As part of this effort, the NDDH requested that Argonne National Laboratory (Argonne) conduct a radiological dose and risk assessment of the disposal of TENORM wastes in permitted Industrial Waste and Special Waste Landfills in North Dakota.

This report presents the results of Argonne's radiological dose and risk assessment. Specifically, it presents results associated with the following:

- Worker exposures to TENORM wastes associated with well site operations,

- Accidental public exposures associated with improperly managed well site operation wastes (e.g., filter socks) and materials (e.g., proppants),

- Worker and public exposures associated with transportation of TENORM wastes to landfills, and

- Worker and public exposures associated with TENORM disposal Industrial and Special Waste Landfills permitted in North Dakota.

In addition, this report presents information supporting these dose and risk assessments. The document is organized as follows:

- Section 2 presents information describing the TENORM waste streams generated by the petroleum industry in North Dakota;

- Section 3 presents information about landfill disposal, including design criteria for permitted Industrial Waste and Special Waste Landfills in North Dakota and assumptions used to define the well site and landfill exposure scenarios;

- Section 4 presents the models and methods used to assess (1) the fate and transport of TENORM, including modeling of the subsurface hydrologic regime, and (2) radiological dose and risk; 
- Section 5 presents the results of the hydrologic modeling;

- Section 6 presents the results of the radiological dose and risk assessments;

- Section 7 presents conclusions and recommendations;

- Appendix A presents the radionuclide analysis data for TENORM waste samples collected in North Dakota;

- Appendix B presents parameter values used in the dose and risk assessment models; and

- Appendices $\mathrm{C}$ through $\mathrm{E}$ present various groundwater-related data and results. 


\section{TENORM WASTE STREAMS}

Some oil and gas production and development activities can cause NORM to accumulate in certain waste streams in concentrations above background. This material is often referred to as TENORM to distinguish it from other forms of NORM that are not by-products of some form of processing. The State of North Dakota uses the term TENORM in its regulations. This section describes the TENORM waste generated by oil and gas operations in North Dakota.

In the United States, the sources for elevated TENORM levels are uranium-238 (U-238) and thorium-232 (Th-232), which are naturally present in underground formations from which oil and gas are produced. The primary radioisotopes of concern in petroleum industry wastes are radium-226 (Ra-226) and radium-228 (Ra-228), which result from the radioactive decay of U-238 and Th-232, respectively, and their associated decay products. The primary radionuclide of concern (ROC) for the gas industry is lead-210 (Pb-210), which forms a scale inside the pipes and equipment containing natural gas. $\mathrm{Pb}-210$ is a decay product of gaseous radon-222 (Rn-222), which comes from the radioactive decay of Ra-226.

The oil and gas waste streams known to potentially contain elevated TENORM concentrations include:

1. Produced water, which is formation water that is brought to the surface along with the produced oil and gas;

2. Scale, which is a hard, insoluble deposit that accumulates on the inside surfaces of the equipment used at production facilities, and solid debris that comes in contact with produced water;

3. Sludge, which is a slightly granular, usually hydrocarbon-rich deposit that accumulates in the bottom of some storage and process vessels;

4. Filter cake, which is material collected inside filters used to remove particulates from produced water and flowback water or from treating other oilfield wastes to remove liquids for sale or disposal; and

5. Disposable filter socks, which are used to filter particulates out of produced water prior to transport and disposal.

Production and processing equipment that contain residual quantities of theses wastes and soils that have been impacted by theses wastes also create a TENORM waste management issue if radionuclide concentrations are high enough to present a human health risk. In addition, some synthetic proppants used during well fracturing activities are known to contain low levels of activity, thus presenting another source of potential exposure. The following sections provide more detailed descriptions of each of these TENORM waste streams. Waste streams explicitly included in the scope of the worker and public exposure risk analysis include scales, sludges and filter cake, filter socks, natural gas processing equipment, and proppants. 
For this study, the NDDH worked with industry partners to collect data on activity concentrations from typical TENORM waste streams generated in the state. Table 2.1 summarizes the average, median, minimum, and maximum activity concentrations for the four radionuclides evaluated ( $\mathrm{Ra}-226, \mathrm{Ra}-228, \mathrm{~Pb}-210$, and $\mathrm{Th}-232)$, along with the number of samples for each waste type. The analytical results supporting the summary data in Table 2.1 are presented in Appendix A. The number of samples varied by radionuclide for a given waste stream, since not all radionuclides were measured for all samples. While all samples included Ra-226 and Ra-228, other radionuclides, such as Th-232 and Pb-210, were only measured for a subset of the samples.

Previous TENORM risk assessment studies have not typically included thorium because of a lack of data. In addition, state regulations on TENORM and NORM disposal generally impose limits based upon total radium ( $\mathrm{Ra}-226$ + Ra-228) activity concentrations. However, given that the data provided showed the presence of Th-232 in a large number of waste samples, it was included in this analysis. Figure 2.1 shows the distribution of the ratio of Th-232 activity concentration measured in each sample to the total radium concentration. The average value for

TABLE 2.1 North Dakota TENORM Waste Characterization Data

\begin{tabular}{lrrrr}
\hline \multicolumn{1}{c}{ Type of Waste } & Scale & Sludge $^{\mathrm{a}}$ & Filter Sock & Proppant \\
\hline & & & & \\
Average Ra-226 (pCi/g) & 548 & 58.3 & 32.8 & 8.2 \\
Median Ra-226 (pCi/g) & 134 & 24.5 & 6.9 & 8 \\
Minimum Ra-226 (pCi/g) & 9.4 & 2 & 0.9 & 1.8 \\
Maximum Ra-226 (pCi/g) & 4,710 & 1,230 & 374 & 9.1 \\
Number of samples & 38 & 57 & 18 & 6 \\
& & & & \\
Average Ra-228 (pCi/g) & 332 & 15.4 & 13.8 & 9.9 \\
Median Ra-228 (pCi/g) & 66.2 & 9.7 & 5.6 & 9.8 \\
Minimum Ra-228 (pCi/g) & 2.6 & 0.5 & 2.4 & 3.1 \\
Maximum Ra-228 (pCi/g) & 3,590 & 66.3 & 130 & 11.2 \\
Number of samples & 38 & 57 & 18 & 6 \\
& & & & \\
Average Pb-210 (pCi/g) & 5,270 & 67.2 & 36.9 & 8.5 \\
Median Pb-210 (pCi/g) & 5,270 & 31.1 & 5 & 8.6 \\
Minimum Pb-210 (pCi/g) & 5,270 & 2.1 & 3.5 & 6.2 \\
Maximum Pb-210 (pCi/g) & 5,270 & 318 & 70 & 9.74 \\
Number of samples & 1 & 7 & 17 & 6 \\
& & & & \\
Average Th-232 (pCi/g) & 71.7 & 17.2 & 12.7 & 9.1 \\
Median Th-232 (pCi/g) & 40.3 & 9.4 & 12.7 & 9.2 \\
Minimum Th-232 (pCi/g) & 6.5 & 2.1 & 6.5 & 8.1 \\
Maximum Th-232 (pCi/g) & 460 & 97.5 & 18.9 & 10.2 \\
Number of samples & 27 & 50 & 2 & 6 \\
\hline & & & &
\end{tabular}

a Filter cake is assumed to have a similar composition to sludge.

Sources: Radig (2013a, 2014a-c); Poppke (2014). 


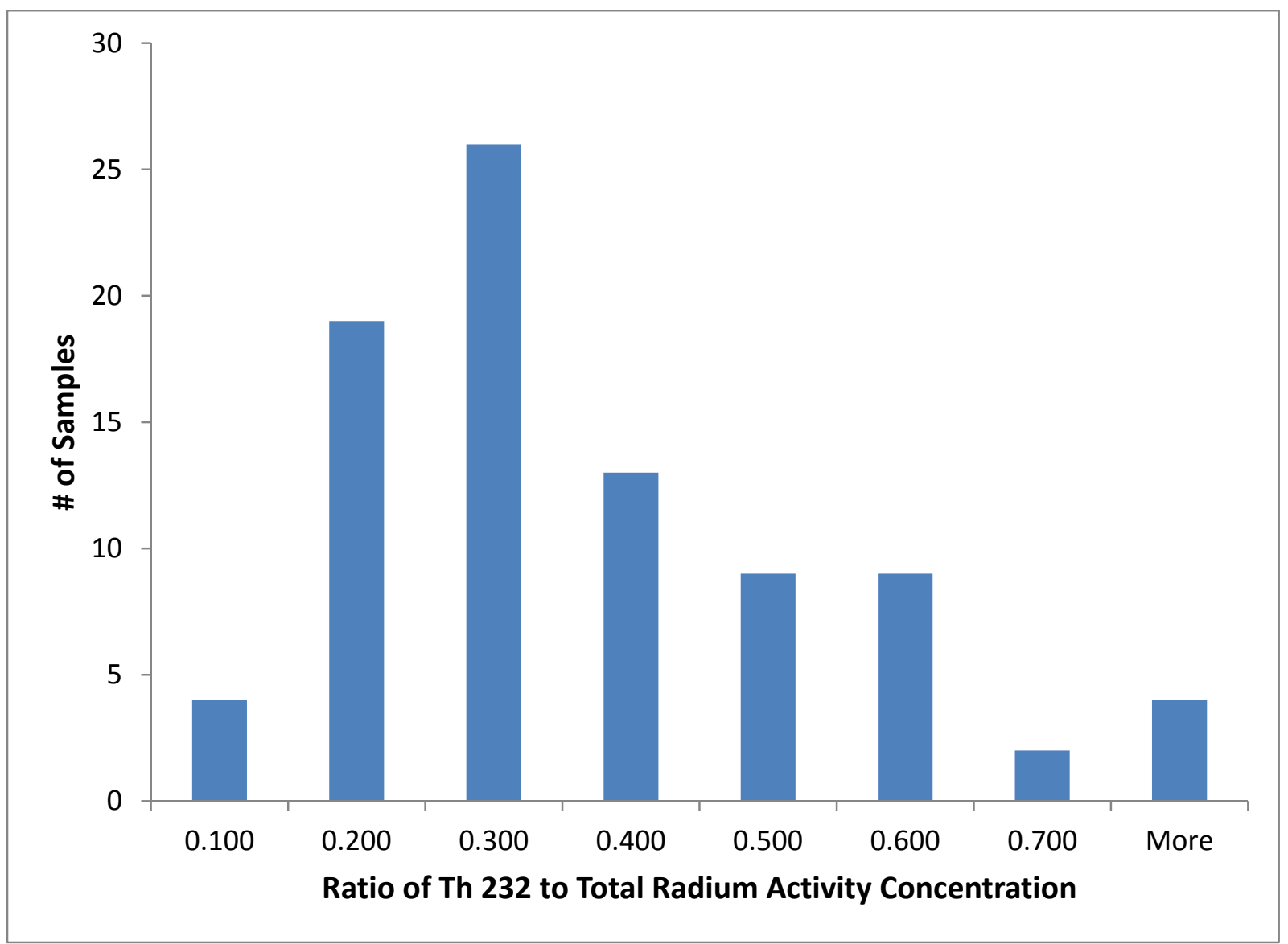

FIGURE 2.1 Histogram Illustrating the Distribution of the Ratio of Th-232 to Total Radium Activity Concentrations from All Samples Where Th-232 Was Measured

this ratio was 0.31 , with a standard deviation (SD) of 0.18 and a maximum value of 0.94 . This ratio was used to help estimate acceptable waste acceptance criteria based upon total radium concentrations.

\subsection{PRODUCED WATER}

The production of formation water is one of the primary mechanisms for bringing TENORM radionuclides to the surface where they can become waste management and worker protection issues. The radionuclides found in produced water generally include Ra-226, Ra-228 and their decay products; elemental uranium and thorium typically have not been found in produced water in the United States. Radium, which is more soluble than either uranium or thorium, can be mobilized in formation water and transported to the surface in the produced water stream. As the produced water is brought to the surface, some of the dissolved radium precipitates out in solid form, either in scales or sludges. Some portion of the radium, however, remains in solution in the produced water stream. The majority of produced water generated in the United States is disposed of in saltwater disposal wells. This waste stream was excluded from 
this risk assessment, except for activities associated with produced water filtration at the well site. Throughout this report, the term produced water is used to encompass all water that is produced from the well, including flowback water which is produced in the first few days following well treatment (e.g., hydrofracturing).

\subsection{SCALE}

In the United States, scale deposits that accumulate inside production and processing equipment and on solid debris (e.g., sand grains) that comes in contact with produced water typically take the form of hard and relatively insoluble deposits of barium sulfate $\left(\mathrm{BaSO}_{4}\right)$ or strontium sulfate $\left(\mathrm{SrSO}_{4}\right)$. When in solution in the produced water, the radium can co-precipitate with the sulfate scales. These radium-bearing scales become a waste management issue when they are removed when equipment is serviced and cleaned.

\subsection{SLUDGE AND FILTER CAKE}

TENORM-contaminated sludges can accumulate in the bottom of vessels that are used to store or otherwise manage produced water, including water storage tanks, oil/water separators, and heater treaters. Sludges typically are composed of solid debris, such as sand, scale, or rust particles, that settle out of the production stream. The primary ROCs in sludges in the United States are Ra-226, Ra-228, and their decay products, although data obtained from North Dakota indicate that Th-232 may be present as well. Typically, the radium takes the form of a co-precipitate with sulfate or carbonate deposits. In addition, filters that are used to separate particulates from produced water generate a solid waste referred to as filter cake. This material is likely to have a similar composition to the sludge that is removed from produced water storage and handling equipment.

\subsection{FILTER SOCKS}

Disposable filter socks are used to filter particulates out of produced water prior to transport and disposal. These filters accumulate sludges and scales over time and must be changed and disposed of on a regular basis. In the past year, the improper disposal of these filter socks has become a major problem in the State of North Dakota (Donovan 2014a,b). This assessment evaluated potential risks to workers that handle filter socks and to the general public resulting from accidental exposures to filter socks that have been improperly disposed of.

\subsection{LEAD-210 DEPOSITS IN GAS EQUIPMENT}

Thin films of $\mathrm{Pb}-210$ may accumulate on the inside surfaces of gas production and processing equipment. The source of the $\mathrm{Pb}-210$ is considered to be gaseous $\mathrm{Rn}-222$, which is a component of natural gas from many formations. The $\mathrm{Pb}-210$ may be present in elemental form, as a chemical precipitate, or as an integrated constituent of the equipment metal. When compared 
with published information on radium-bearing TENORM wastes, very little information has been published characterizing petroleum industry wastes containing $\mathrm{Pb}-210$. The NDDH did not collect data describing $\mathrm{Pb}-210$ contamination at gas facilities in North Dakota. For this waste stream, data collected for a previous Argonne analysis were used. That study found an average concentration of $260 \mathrm{pCi} / \mathrm{g}$ and a maximum concentration of $10,000 \mathrm{pCi} / \mathrm{g}$ for $\mathrm{Pb}-210$ in gas processing equipment (Smith et al. 1999).

\subsection{TENORM-CONTAMINATED EQUIPMENT}

Production and processing equipment that contain residual quantities of TENORMcontaminated water, scales, sludges, or films can present a waste management problem if radionuclide concentrations are high enough. TENORM-contaminated equipment that cannot be easily cleaned (e.g., wellhead filters, valves, or screens), or is otherwise ready for disposal at an approved disposal facility (e.g., equipment that is no longer functional), must be managed appropriately. Data describing the potential volume of this waste stream have not been collected in North Dakota. This waste stream was not included in the scope of this risk assessment.

\subsection{TENORM-CONTAMINATED SOILS}

Soils that have been impacted by TENORM-contaminated wastes, such as produced water, scales, or sludges, can present a waste management problem if radionuclide concentrations are high enough. Soils may become contaminated through the intentional application or accidental release of contaminated wastes. For example, the practice of disposing of oily wastes by landspreading can inadvertently result in the distribution of TENORM wastes across the affected soils. Similarly, soils in unlined or leaking disposal pits can become contaminated with TENORM. Overall, contaminated soils will likely represent only a small portion of the total TENORM waste stream (Radig 2013a). As a result, this waste stream was not included in the scope of this risk assessment.

\subsection{SYNTHETIC FRACTURING PROPPANT}

A proppant is a solid material, treated sand, or man-made ceramic material designed to keep an induced hydraulic fracture open during or following a fracturing treatment. Some synthetic fracturing proppants, which consist of small, ceramic beads made from bauxite, have been shown to contain low levels of radioactivity. While these materials are not currently regulated as radioactive material, proppant that has been spilled or becomes unusable is a solid waste and may need to be disposed of as radioactive waste. The total quantity of proppant that might need to be disposed of is not currently known but is thought to be a small fraction of the total TENORM waste stream. The disposal of this waste stream in landfills was not included in the scope of this risk assessment; however, accidental general public exposures to improperly managed proppants were included. 
This page intentionally left blank. 


\section{LANDFILL DISPOSAL AND POTENTIAL EXPOSURE SCENARIOS}

This section provides a general description of the two different landfill designs evaluated in this risk assessment, as well as the well site and landfill exposure pathways that were evaluated.

\subsection{LANDFILL DISPOSAL}

Landfills are used to dispose of a wide variety of wastes, and, typically, the degree of engineering control increases with the hazard level of the wastes. Landfills are categorized by the types of waste streams that can be accepted for disposal; regulatory requirements vary by landfill category. In general, waste disposal in properly constructed landfills that are equipped with liners, a leachate collection system (LCS), and other active and passive institutional controls provides a high degree of isolation from humans and the environment. In the United States, a variety of petroleum industry wastes are disposed of in landfills, usually in landfills designed and regulated for industrial wastes, or specifically for petroleum industry wastes. These wastes include scales, sludges, contaminated soils, excess equipment, and other solid debris. TENORMcontaminated wastes also are disposed of in landfills; however, this practice is typically limited to disposal in landfills specifically licensed for either TENORM or regulated low-level radioactive wastes (LLW). The costs associated with disposal in these types of landfills are generally quite high, because the higher costs incurred in the United State for constructing and operating licensed TENORM or LLW disposal facilities are passed on to the customers. One state (Michigan) allows the disposal of solid waste and debris containing an average Ra-226 concentration less than or equal to $50 \mathrm{pCi} / \mathrm{g}$ in landfills permitted to accept nonhazardous municipal wastes, which translates into lower costs (Michigan Department of Environmental Quality 2007).

In North Dakota, the landfill types evaluated in this study included Small Volume Industrial Waste Landfills and Special Waste Landfills ("Special Waste Landfills") and Large Volume Industrial Waste and Municipal Solid Waste Ash Landfills ("Industrial Waste Landfills"), which differ in design requirements specified by the North Dakota Administrative Code (NDAC) (2014). North Dakota regulations do not currently allow the disposal of radioactive wastes in either of these two landfill types.

The rules for Small Volume Industrial Waste Landfills and Special Waste Landfills (NDAC; Chapter 33-20-07.1) ("Special Waste Landfills") pertain to oilfield special waste (Radig 2013a). These landfills require a composite liner consisting of at least $1 \mathrm{~m}(3 \mathrm{ft})$ of recompacted clay with a hydraulic conductivity $(\mathrm{K})$ less than $1 \times 10^{-7} \mathrm{~cm} / \mathrm{s}\left(3 \times 10^{-9} \mathrm{ft} / \mathrm{s}\right)$ overlain with a flexible membrane liner with a thickness of at least $1.5 \times 10^{-3} \mathrm{~m}(60 \mathrm{mil})$. A drainage layer above the liner must have a K exceeding $1 \times 10^{-3} \mathrm{~cm} / \mathrm{s}\left(3.3 \times 10^{-5} \mathrm{ft} / \mathrm{s}\right)$ and a sufficient thickness to provide a transmissivity of at least $3 \times 10^{-2} \mathrm{~cm}^{2} / \mathrm{s}\left(3.2 \times 10^{-5} \mathrm{ft}^{2} / \mathrm{s}\right)$. The liner and the LCS must maintain their integrity during the operational period and the post-closure period. The final cover of the landfill must include a bottom layer of compacted soil with a K less than $1 \times 10^{-7} \mathrm{~cm} / \mathrm{s}$ $\left(3.3 \times 10^{-9} \mathrm{ft} / \mathrm{s}\right)$, at least $0.5 \mathrm{~m}(1.5 \mathrm{ft})$ thick; a clay-rich soil, suitable as a plant root zone, at least 
$0.3 \mathrm{~m}(1 \mathrm{ft})$ thick, and at least $0.15 \mathrm{~m}(0.5 \mathrm{ft})$ of topsoil. During the operational phase, the liners and LCS must collect at least $90 \%$ of the precipitation that falls on the landfill and must be

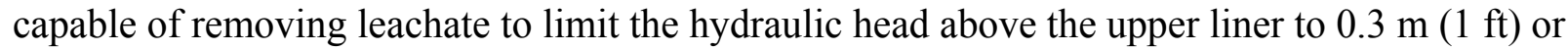
less. At closure, landfills must be revegetated with a mixture of adapted native grasses to minimize erosion and promote evapotranspiration of rain and snowmelt, thus helping to minimize infiltration. During post-closure, the final cover and liner system must collect or reject $98.5 \%$ of the precipitation. The post-closure period is a minimum of 30 years (NDAC; Chapter 33-20-04.1-09(5)(b)).

Large Volume Industrial Waste and Municipal Solid Waste Ash Landfills (NDAC; Chapter 33-20-10) ("Industrial Waste Landfills") require a double liner and LCS. The bottom

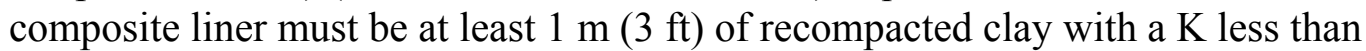
$1 \times 10^{-7} \mathrm{~cm} / \mathrm{s}\left(3.3 \times 10^{-9} \mathrm{ft} / \mathrm{s}\right)$ overlain with a flexible membrane liner with a thickness of at least $1.5 \times 10^{-3} \mathrm{~m}(60 \mathrm{mil})$. Above this is the lower drainage layer with a K exceeding $1 \times 10^{-3} \mathrm{~cm} / \mathrm{s}$ $\left(3.3 \times 10^{-5} \mathrm{ft} / \mathrm{s}\right)$ and a sufficient thickness to provide a transmissivity of at least $3 \times 10^{-2} \mathrm{~cm}^{2} / \mathrm{s}$ $\left(3.2 \times 10^{-5} \mathrm{ft}^{2} / \mathrm{s}\right)$. Above the lower drainage layer, the second liner is a flexible membrane liner with a thickness of at least $2.0 \times 10^{-3} \mathrm{~m}(80 \mathrm{mil})$, above which is the upper drainage layer with a $\mathrm{K}$ exceeding $1 \times 10^{-3} \mathrm{~cm} / \mathrm{s}\left(3.3 \times 10^{5} \mathrm{ft} / \mathrm{s}\right)$ and a sufficient thickness to provide for a transmissivity of at least $3 \times 10^{-2} \mathrm{~cm}^{2} / \mathrm{s}\left(3.2 \times 10^{-5} \mathrm{ft}^{2} / \mathrm{s}\right)$. A leachate detection and removal system must be included, and an impoundment to contain leachate may be required by the state. The final cover of the landfill must be at least $2.4 \mathrm{~m}(8 \mathrm{ft})$ thick, including a composite cover consisting of a bottom layer of compacted soil with a K less than $1 \times 10^{-7} \mathrm{~cm} / \mathrm{s}\left(3.3 \times 10^{-9} \mathrm{ft} / \mathrm{s}\right)$ at least $0.6 \mathrm{~m}(2 \mathrm{ft})$ thick overlain with a flexible membrane liner with a thickness of at least $1.5 \times 10^{-3} \mathrm{~m}(60 \mathrm{mil})$. Above this is a drainage layer with a $\mathrm{K}$ exceeding $1 \times 10^{-3} \mathrm{~cm} / \mathrm{s}$ $\left(3.3 \times 10^{-5} \mathrm{ft} / \mathrm{s}\right)$ and a sufficient thickness to provide for a transmissivity of at least $3 \times 10^{-2} \mathrm{~cm}^{2} / \mathrm{s}$ $\left(3.2 \times 10^{-5} \mathrm{ft}^{2} / \mathrm{s}\right)$. Above the drainage layer is a soil layer at least $1 \mathrm{~m}(3 \mathrm{ft})$ thick to protect the

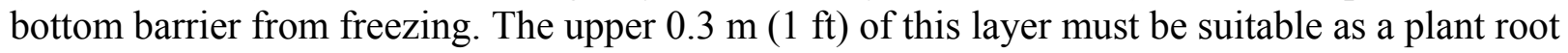
zone. The top layer must be at least $0.15 \mathrm{~m}(0.5 \mathrm{ft})$ of topsoil. During the operational phase, the liners and LCS must collect at least $97 \%$ of the precipitation that falls on the landfill and must be

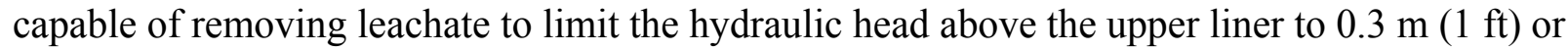
less within 36 hours of a precipitation event. During post-closure, the final cover, liner system, and LCS must collect or reject $99.9 \%$ of the precipitation that falls on the landfill. The post-closure period is a minimum of 30 years (NDAC; Chapter 33-20-04.1-09(5)(b)).

Table 3.1 describes the six landfills permitted in 2013 in North Dakota holding permits as Large Volume Industrial Waste or Special Waste Landfills. The locations of these and other Special Waste Landfills are shown in Figure 3.1. One landfill, Chimney Butte, has an alternative final cover system consisting of an evapotranspirative cover of $1.5 \mathrm{~m}(5 \mathrm{ft})$ of uncompacted soil (Radig 2013b). Average dimensions of these landfills are used to define the generic landfill evaluated in this study. These average values include a total size of 19 ha (46 acres), a waste thickness of $38 \mathrm{~m}(125 \mathrm{ft})$, a total volume of $3,600,000 \mathrm{~m}^{3}\left(4,700,000 \mathrm{yd}^{3}\right)$, and a life expectancy of 18.8 years. Per Radig (2013c), the total volume of TENORM wastes that would be shipped to a single landfill per year was assumed to be 25,000 tons.

Rules for Surface Impoundment Provisions (NDAC; Chapter 33-20-08.1) would be in effect for landfill LCSs that manage leachate on-site. New impoundments are required to have a 
TABLE 3.1 Large Volume Industrial Waste Landfill and Special Waste Landfills Permitted in North Dakota in 2013

\begin{tabular}{|c|c|c|c|c|c|c|c|c|}
\hline \multirow[b]{2}{*}{ Landfill Name } & \multirow[b]{2}{*}{ Landfill Type } & \multicolumn{2}{|c|}{ Total Size } & \multicolumn{2}{|c|}{$\begin{array}{c}\text { Maximum Waste } \\
\text { Thickness }\end{array}$} & \multicolumn{2}{|c|}{ Total Volume } & \multirow{2}{*}{$\begin{array}{l}\text { Expected Life } \\
\text { of Facility } \\
\text { (yr) }\end{array}$} \\
\hline & & (ha) & (acre) & $(\mathrm{m})$ & $(\mathrm{ft})$ & $\left(\mathrm{m}^{3}\right)$ & $\left(\mathrm{yd}^{3}\right)$ & \\
\hline $\begin{array}{l}\text { Clean Harbors - } \\
\text { Cell D }\end{array}$ & $\begin{array}{l}\text { Large volume } \\
\text { industrial waste }\end{array}$ & 19 & 47 & 32 & $\sim 105$ & $2,973,000$ & $3,889,000$ & 13.0 \\
\hline $\begin{array}{l}\text { Marquis Alliance } \\
-13 \text { Mile }\end{array}$ & Special waste & 19 & 48 & 51 & $\sim 168$ & $3,742,000$ & $4,895,000$ & 22.0 \\
\hline Nuverra - Ideal & Special waste & 7.6 & 18.9 & 30 & $\sim 100$ & $1,332,000$ & $1,741,840$ & 8.7 \\
\hline $\begin{array}{l}\text { Section } 18 \text { - } \\
\text { Chimney Butte }\end{array}$ & Special waste & 31 & 76.2 & 38 & $\sim 126$ & $7,397,000$ & $9,674,891$ & 30.0 \\
\hline $\begin{array}{l}\text { Tervita - Blue } \\
\text { Buttes }\end{array}$ & Special waste & 24 & 59 & 26 & $\sim 85$ & $3,809,000$ & $4,981,450$ & 23.2 \\
\hline WISCO & Special waste & 10 & 25.5 & 50 & $\sim 165$ & $2,447,000$ & $3,200,000$ & 16.0 \\
\hline
\end{tabular}

Source: Radig (2013c).

liner of at least $1.2 \mathrm{~m}(4 \mathrm{ft})$ of compacted soil with a $\mathrm{K}$ less than $1 \times 10^{-7} \mathrm{~cm} / \mathrm{s}\left(3.3 \times 10^{-9} \mathrm{ft} / \mathrm{s}\right)$, or a combination of a soil liner and/or flexible liner to control the migration of waste during the impoundment's operational period and, for impoundments closed with solid waste in place, during the post-closure period. At closure, two options are available for an impoundment. One is to remove standing liquids, waste, waste residues, liners, any leak detection system, and any underlying or surrounding contaminated soil. This would be followed by regrading and restoration. The other option is to treat liquids, residues, and soils by removal of liquids, drying, or other means and then provide post-closure care under Industrial Waste Landfill rules.

At several landfills in North Dakota, leachate is managed within evaporation ponds that typically have a composite liner. Any TENORM that mobilizes into the leachate will accumulate within these evaporation ponds over time and will either result in increasing TENORM concentrations within the aqueous phase or form precipitates or scale at the bottom of the evaporation ponds. Furthermore, the use of fans or spray systems to enhance the evaporation rate from the ponds may result in the formation of aerosols containing TENORM, which may travel downwind of the ponds. Radig (2014d) described impoundments used as leachate evaporation ponds. They range in size from 0.3 to 2 ha ( 0.8 to 5 acres) (most are 0.6 to 1 ha, or 1.5 to 2.5 acres) and in capacity from 5,160 to $65,100 \mathrm{~m}^{3}(1,363,000$ to $17,200,000$ gal (most 7,600 to $13,000 \mathrm{~m}^{3}$, or 2 to 3.5 million gal). They have a liner of $0.6 \mathrm{~m}(2 \mathrm{ft})$ of compacted clay and $1.5 \times 10^{-3} \mathrm{~m}(60 \mathrm{mil})$ high-density polyethylene (HDPE), or a liner of double HDPE (usually $2.0 \times 10^{-3} \mathrm{~m}$ or $80 \mathrm{mil}$ upper and $1.5 \times 10^{-3} \mathrm{~m}$ or 60 mil lower) with a geo-net drainage layer in between. Some oilfield special waste facilities dispose of some of their leachate at injection wells in accordance with state or federal rules. 


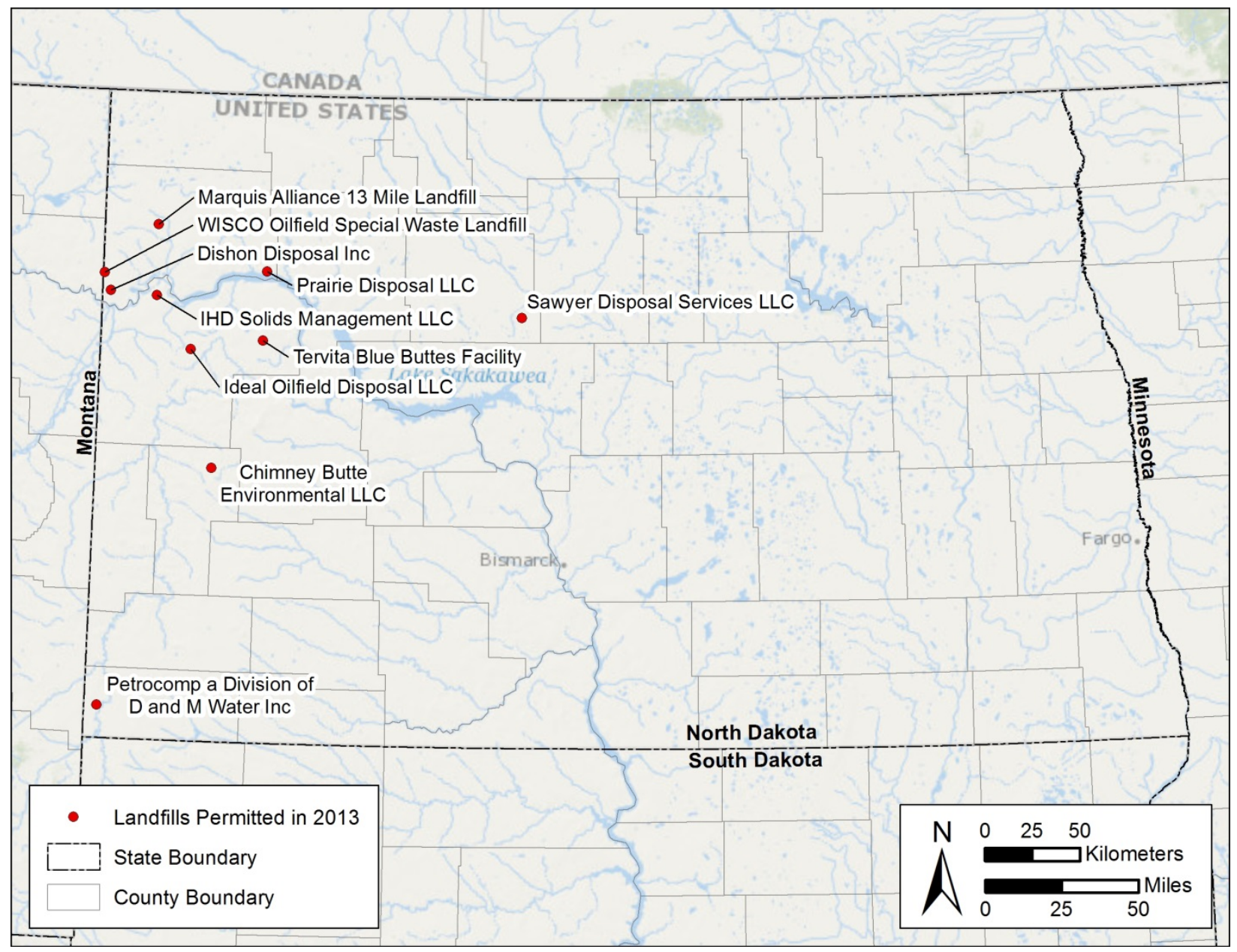

FIGURE 3.1 Special Waste Landfills Permitted in North Dakota

\subsection{EXPOSURE SCENARIOS AND ANALYSIS}

The potential exposure scenarios related to landfill disposal of TENORM can be grouped into two major categories: operational phase scenarios and future-use scenarios. Operational phase scenarios were evaluated to estimate the potential exposures resulting from well site operations, transportation of TENORM from production facilities to generic landfill sites, and landfill operations. Future-use scenarios evaluated potential risks to receptors at points of time in the future after the operational phase has been completed (i.e., after the landfill is closed). While the exposure scenarios strive to be as complete as possible, in general, the scenarios model the maximally exposed individual (MEI); that is, the individual who is most likely to receive the largest dose and incur the greatest risk. This type of analysis is performed in order to estimate an upper-bound risk for a particular operation.

Specific information about the exposure scenarios is provided in the following sections. 


\subsubsection{Operational Phase Scenarios}

Operational phase scenarios were evaluated to estimate potential exposures resulting from well site operations, transportation, and landfill operations. They evaluate the dose to both the workers (e.g., workers at the well sites, truck drivers during transportation, and landfill workers) and members of the public (e.g., potential exposure to improperly managed filter socks and proppants, persons living along the transportation corridors, and persons living in the vicinity of the landfill during operations). The public exposures related to well site operations were not evaluated because the majority of the materials produced at well sites are wet and produce very little airborne emissions, and because the general public is not typically present at the well site, such that external exposure would be significantly less than for the on-site workers evaluated. In general, exposure pathways considered for the operational phase included external radiation, inhalation of contaminated dust, and incidental ingestion of contaminated soil or sand.

\subsubsection{Well Site Operations Scenarios}

The doses were estimated for well pad workers involved in mixing hydraulic fracturing fluid and filtering produced water; equipment cleaning workers involved in pipe cleaning, storage tank cleaning, and gas processing equipment cleaning; disposal well workers involved in filtration and connecting/disconnecting trucks; and sludge treatment plant workers involved with treating and managing sludge. ${ }^{1}$ Assumptions for these worker scenarios are presented in Table B.1 of Appendix B and include the following:

- Hydraulic Fracturing Fluid Mixing Worker. It was assumed that exposure is from the blending operations in the sand blender and that only the direct external exposure is an applicable pathway. The inhalation and ingestion pathways were excluded because of the assumed use of personal protective equipment (PPE) (e.g., respirators, eye protection, and gloves).

- Produced Water Filtration Worker. Most of the dose is from incidental ingestion. The inhalation pathway was excluded because of the wet nature of the process. It was assumed that this worker does not wear PPE.

- Equipment Cleaning Worker Scenarios. It was assumed that equipment cleaning workers are involved in removing scale and sludge or Pb-210 film from equipment taken out of service. The types of equipment that are cleaned for reuse include piping and storage tanks. Three types of workers were modeled: pipe cleaners and storage tank cleaners working in the oil industry,

1 For the purposes of estimating doses associated with each task, it was assumed that a single worker would perform only one task. For each scenario, a conservatively high number of hours per year was assumed. In reality, a worker may perform multiple tasks, some of which could also involve exposure to TENORM, and others that might not involve any exposure. Potential doses of individual workers should be assessed on the basis of their actual work assignments. 
and equipment cleaners working at a gas industry processing facility. Only the individual who would come in direct contact with the contaminated equipment was modeled (this individual is likely to have greater exposure). It was assumed that respiratory protection was used and that the receptor was exposed only by the direct external exposure due to the use of PPE.

- Sludge Treatment Worker Scenario. It was assumed that sludge treatment workers are involved in treating the sludge generated during the well site operations (e.g., dewatering wastes to meet landfill acceptance criteria). Parameters for sludge treatment workers were assumed to be similar to the parameters for storage tank cleaning workers. However, sludge treatment workers would be shielded by water in the tanks and the exposure duration would be higher. No exposure from inhalation and ingestion pathways was assumed for sludge treatment workers because it was assumed that workers use PPE.

Doses also were estimated for the public resulting from improperly managed filter socks and proppants. Filter socks are used to filter wastewater at drilling sites. They look like small nets and could be mistaken for an item that children could use for play or for fishing. A proppant is a solid material, treated sand, or man-made ceramic material, designed to keep an induced hydraulic fracture open during or following a fracturing treatment. It is added to a fracking fluid.

Three accidental exposure scenarios were evaluated: two filter sock exposure scenarios and one proppant exposure scenario. Assumptions for these accidental public exposure scenarios are presented in Table B.2 of Appendix B and include the following:

- Filter Socks Used as a Toy. It was assumed that a number of filter socks are collected by a child and used as a toy for play, with an assumed exposure of 24 hours over the course of a year; the exposure pathways considered included direct external exposure and inadvertent ingestion of radionuclides.

- Filter Socks Disposed of in a Dumpster. It was assumed that a number of used filter socks were dumped in a city dumpster and that a city dweller was exposed to the dumpster for 8 hours every day for 5 days (total exposure of 40 hours over the course of a year). The exposure pathway considered was direct external exposure.

- Proppant Used at a Playground. It was assumed that a truckload of proppant material was illegally dumped in an open field. Children used that area as their playground and spent 2 hours every day for 50 days (total exposure of 100 hours over the course of a year). Children were exposed by direct external exposure, inhalation, and ingestion pathways. 


\subsubsection{Transportation Scenarios}

The transportation operations evaluated in this assessment included loading the cargo onboard, transport of the material to its final destination, and any stops for maintenance or refueling along the way. The potential receptors included the driver of the transportation vehicle (truck transport only), persons living along the transportation corridor, persons sharing the transportation corridor, persons at stops for refueling or maintenance, as well as persons living near the entrance of the landfill site. Parameters used for the transportation scenarios are presented in Table B.7 of Appendix B.

\subsubsection{Landfill Operations Scenarios}

Two types of landfill operators were evaluated: a waste-placement operator, and a leachate management worker. The waste-placement operator was assumed to be involved with activities related to receiving and sampling the waste (e.g., reviewing the manifest, weighing the truck, and inspecting the shipment), as well as directing placement of the waste while standing in the vicinity of the truck and also moving and compacting waste in the disposal cell. It was assumed that all wastes have been dewatered prior to shipment to the landfill in accordance with North Dakota landfill waste acceptance criteria (NDAC; Chapter 33-20-01.1). Potential routes of exposure for the waste-placement operator included external irradiation, inhalation of contaminated particulates, and inadvertent ingestion of contaminated particulates. Inhalation of particulates were not considered a potential pathway of exposure for instances in which the wastes are disposed of in containers. Exposure times were estimated based on the volume of material disposed of and typical handling procedures at the landfill. ${ }^{2}$ Parameters used for the landfill operations scenarios for containerized and bulk waste are presented in Tables B.3 and B.4 of Appendix B, respectively.

It was assumed that the leachate worker is responsible for managing the leachate generated at the landfill, and that the leachate generated will be collected in an evaporation pond. Depending on the evaporation pond operation, potential routes of exposure for the pond management worker included external irradiation, inhalation of contaminated particulates, and inadvertent ingestion of contaminated particulates. Parameters used for the evaporation pond operations scenarios are presented in Table B.5 of Appendix B.

Doses and health risks resulting from potential airborne emissions generated during waste placement of bulk wastes also were evaluated for the population living near the landfill.

2 For each landfill operations scenario, the dose is estimated on the basis of the duration of the operation, source geometry, and total activity and mass of the waste disposed of in 1 year at the landfill. The number of times an operation is performed and the mass involved in each operation are calculated internally in the code. For example, in the TSD-DOSE code, the only input parameters required for receiving and handling operation are waste density (required to estimate the mass in each shipment), the time required to inspect one shipment, and the average distance the operator is from the waste. The code internally estimates the amount of waste and activity in one truckload of shipment and the number of shipments involved, and, from that, calculates the total yearly dose for the receiving and handling scenario. 
Exposures were estimated for the maximally exposed member of the public (i.e., an individual living adjacent to the landfill) and the collective population dose (i.e., the population living within an 80-km [50-mi] radius of the landfill). The primary pathway of exposure is inhalation of contaminated particulates. External irradiation, incidental ingestion of contaminated particulates, and ingestion of contaminated foodstuff also were evaluated for completeness. The residents were assumed to remain at the residences 24 hours a day, 365 days a year. Parameters used for the public exposures regulating from landfill are presented in Table B.4 of Appendix B.

\subsubsection{Future-Use Scenarios}

Future-use scenarios were evaluated to estimate the potential radiation doses and risks associated with activities after the operational phase has been completed. For all pathways, the associated doses and risks were evaluated over a 1,000-year time horizon and considered the fate and transport of the radionuclides through the environment. The only exception is the groundwater pathway. As discussed in Section 4.2, the groundwater pathway was evaluated over 10,000 years to make sure that the maximum dose to a receptor off-site who makes use of the groundwater was captured. The analysis evaluated the disposal of containerized TENORM wastes, as well as bulk wastes. Four future-use scenarios evaluated potential doses to on-site receptors, including an on-site resident, industrial worker, recreational visitor, and intruder. A fifth future-use scenario evaluated potential doses to an individual living adjacent to the landfill after closure who consumes groundwater. In general, the exposure pathways for the future-use scenarios included external radiation; inhalation of contaminated dust; inhalation of radon; and, depending on the particular exposure scenario evaluated, ingestion of contaminated particulates, water, plants, meat, and milk. The parameters utilized for the evaluation of these scenarios are presented in Table B.6 of Appendix B.

North Dakota Solid Waste law and rules emphasize that landfills must combine suitable locations and engineered improvements to minimize impacts on groundwater and surface water. The law and rules stipulate that a perpetual record must be placed on the deed to notify any person conducting a title search that the land has been used as a solid waste disposal facility. The recording must describe the amount and type of waste disposed of and must state that the landfill may not be used for cultivated crops, heavy grazing, buildings, or any other use which might disturb the protective vegetative and soil cover. Given this, the following scenarios are intended to be conservative and do not necessarily represent the most likely uses of the land post landfill closure.

The on-site residential scenario was designed to evaluate a very conservative scenario. Under this scenario, it was assumed that an individual lives on the site; produces most of his or her food on-site, including vegetables, milk, meat, and fish; and uses groundwater derived from the site for both household and agricultural purposes. This scenario may not represent a realistic future use of a landfill property; however, these assumptions are commonly used by risk assessors in evaluating the potential dose to a MEI. The resident was assumed to spend 18 hours each day on-site (12 hours spent indoors), 365 days per year. The likely exposure pathways for the on-site resident included external irradiation and inhalation of indoor and outdoor radon. The following pathways of exposure also were evaluated: inhalation of contaminated particulates; 
inadvertent ingestion of contaminated soil; and ingestion of crops, milk, and meat grown or hunted on the contaminated property.

The industrial land-use scenario considered potential exposures to an individual working inside a building constructed over the landfill. The receptor was assumed to work on-site 8 hours per day, 5 days per week. Exposure time was assumed to consist of 6 hours spent indoors and 2 hours spent outdoors. The exposure pathways evaluated included external irradiation, inhalation of indoor and outdoor radon, inhalation of contaminated particulates, and inadvertent ingestion of soil.

The recreational land-use scenario evaluated potential doses to an individual who visits the former landfill site for recreational use. It was assumed that the recreational visitor makes twenty 1-hour visits to the site each year. The exposure pathways evaluated for the recreational visitor included external irradiation, inhalation of outdoor radon, inhalation of contaminated particulates, inadvertent ingestion of soil, and consumption of meat hunted on the property. Any water used by recreational visitors was assumed to come from an unaffected, off-site supply.

The intruder scenario evaluated potential doses to an individual who accidentally encounters the wastes buried in the landfill after a period of 100 years, at a point in time where the land use and institutional controls are no longer in place to prevent such encounters. It was assumed that an intruder digs a 3-m (9-ft) deep foundation hole for the house. The foundation hole was assumed to be $20 \mathrm{~m}$ by $10 \mathrm{~m}\left(200 \mathrm{~m}^{2}\right)\left(66 \mathrm{ft}\right.$ by $\left.33 \mathrm{ft}\left[239 \mathrm{yd}^{2}\right]\right)$ at the bottom and $26 \mathrm{~m}$ by $16 \mathrm{~m}\left(416 \mathrm{~m}^{2}\right)\left(85 \mathrm{ft}\right.$ by $\left.52 \mathrm{ft}\left[498 \mathrm{yd}^{2}\right]\right)$ at the top (giving a $1: 1$ slope for the sides of the hole.) The top $2 \mathrm{~m}(6 \mathrm{ft})$ of material removed in digging the foundation was assumed to be clean

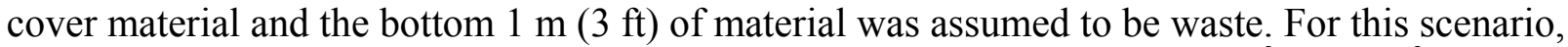
it was assumed that a portion of the soil excavated during the digging $\left(680 \mathrm{~m}^{3}\left[890 \mathrm{yd}^{3}\right]\right.$ of cover material and $232 \mathrm{~m}^{3}\left[303 \mathrm{yd}^{3}\right]$ of waste) would be distributed in a $10,000-\mathrm{m}^{2}$ area $\left(12,000 \mathrm{yd}^{2}\right)$. The intruder was assumed to spend 18 hours each day on-site (12 hours spent indoors), 365 days per year. The likely exposure pathways for the intruder included external irradiation and inhalation of indoor and outdoor radon. The following pathways of exposure also were evaluated: inhalation of contaminated particulates; inadvertent ingestion of contaminated soil; and ingestion of crops, milk, and meat grown or hunted on the contaminated property.

The off-site resident scenario was analyzed to evaluate potential doses resulting from future impacts on the underlying aquifer associated with disposal of TENORM waste in the landfill. It was assumed that the resident lives adjacent to the former landfill property and that all

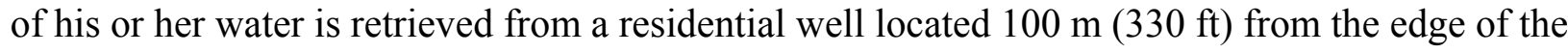
landfill containing the TENORM waste. It was assumed that the individual produces most of his or her food on-site, including vegetables, milk, and meat, and uses groundwater derived from the site for both household and agricultural purposes. The off-site resident was assumed to drink $510 \mathrm{~L}$ (135 gal) of water per year. The exposure pathways for this receptor included ingestion of groundwater and ingestion of crops, milk, and meat produced using the groundwater. Inhalation of radon via volatilization during showering also was considered as a potential pathway of exposure; however, this pathway probably is not a major contributor to dose. 


\subsubsection{Sensitivity Analysis}

Sensitivity analyses were conducted on the parameters for which data are limited or highly variable and for parameters that have a significant impact on estimated doses. Some examples of the parameters selected for sensitivity analysis include the distance between the radiological source and the receptor, location of the MEI, and cover thickness above the TENORM-containing waste (from here on referred to as the depth to TENORM). Sensitivity analysis was conducted by multiplying the base parameter value by a constant and calculating the dose with the new parameter value. This procedure was then repeated; however, rather than multiplying by a constant, the parameter was divided by the same constant value. The sensitivity of a parameter is related to the change in the dose produced by the change in the parameter value. 


\section{MODELING METHODOLOGIES}

This section presents the general modeling approaches that were used to assess (1) fate and transport of TENORM within waste streams, including modeling of the subsurface hydrologic regime, and (2) the human health risk associated with the exposure scenarios described in Section 3.2.

\subsection{PATHWAY ANALYSIS OVERVIEW}

Radiation exposure pathways can be separated into external and internal components. External exposure, which occurs when the radioactive material is outside of the body, is a concern primarily only for gamma radiation because it can easily penetrate tissue and reach internal organs. Internal exposure occurs when the radioactive material is taken into the body through inhalation or ingestion. For internal exposures, alpha and beta particles are the dominant concern because their energy is almost completely absorbed in adjacent cells, potentially causing biological harm.

Exposure to internally deposited radioactive contaminants is expressed in terms of the 50-year committed effective dose equivalent (CEDE). This concept, developed by the International Commission on Radiological Protection (ICRP 1977), represents the weighted sum of the dose equivalent in various organs. The CEDE considers the radiosensitivity of bodily organs, the biological effectiveness of different types of radiation, and variable retention times in the body for different radionuclides. For external pathways, no long-term residence of radionuclides in the body occurs, and the measure of dose is the effective dose equivalent (EDE). Both CEDE and EDE are expressed in units of rem.

The major radiological health concern from exposure to TENORM is the potential induction of cancer. The development of radiation-induced cancer is a stochastic process and is considered to have no threshold dose (i.e., the probability of occurrence, not the severity of effect, increases with dose, and there is no dose level below which the risk is zero). The relationship between radiation dose and the development of cancer is well characterized for high doses of most types of radiation; for low doses, however, it is not well defined and is subject to a large degree of uncertainty. Low levels of radiation exposure may present a health risk, but it is difficult to establish a direct cause-and-effect relationship because of the lack of data and the presence of compounding environmental stresses. In the absence of definitive data, the risks from low levels of radiological exposure are estimated by extrapolating from data available for increased rates of cancers observed at higher doses. For this assessment, radiation doses were converted to carcinogenic risks by using risk factors identified in ICRP Publication 103 (ICRP 2007). The ICRP risk factor for both workers and the public is $5.7 \times 10^{-7}$ per mrem (i.e., 5.7 additional cancer cases in 10 million people for each additional mrem of exposure). Risks are expressed as the increased probability of fatal cancer, nonfatal cancer, and severe hereditary effects over a lifetime. 
As a point of reference, radiation exposures from natural sources of radiation result in an annual dose of about $311 \mathrm{mrem} / \mathrm{yr}$. About $210 \mathrm{mrem} / \mathrm{yr}$ is from exposures to Rn-222 and its short-lived decay progeny, and the rest is from exposures to other natural sources of radiation (NCRP 2009). By applying the ICRP risk factor for the public, the risk of cancer over a lifetime from background radiation is $2 \times 10^{-4}$ per year. In addition, the ICRP recommends that exposures to members of the general public from non-background sources of radiation not exceed $100 \mathrm{mrem} / \mathrm{yr}$ (ICRP 1991). Figure 4.1 shows this limit in relation to other common radiation exposures. This level of exposure was used in the risk assessment for comparison purposes.

The primary health concern from TENORM is related to increased cancer risk from exposure to elevated radiation levels. There is also the possibility of adverse systemic effects due to chemical effects of exposure to the radionuclides. However, based on previous TENORM risk assessments conducted by Argonne (Smith et al. 2005) and due to relatively low concentrations of chemically effective radionuclides (e.g., uranium), the chemical health risks from exposure to radionuclides were not evaluated for this study.

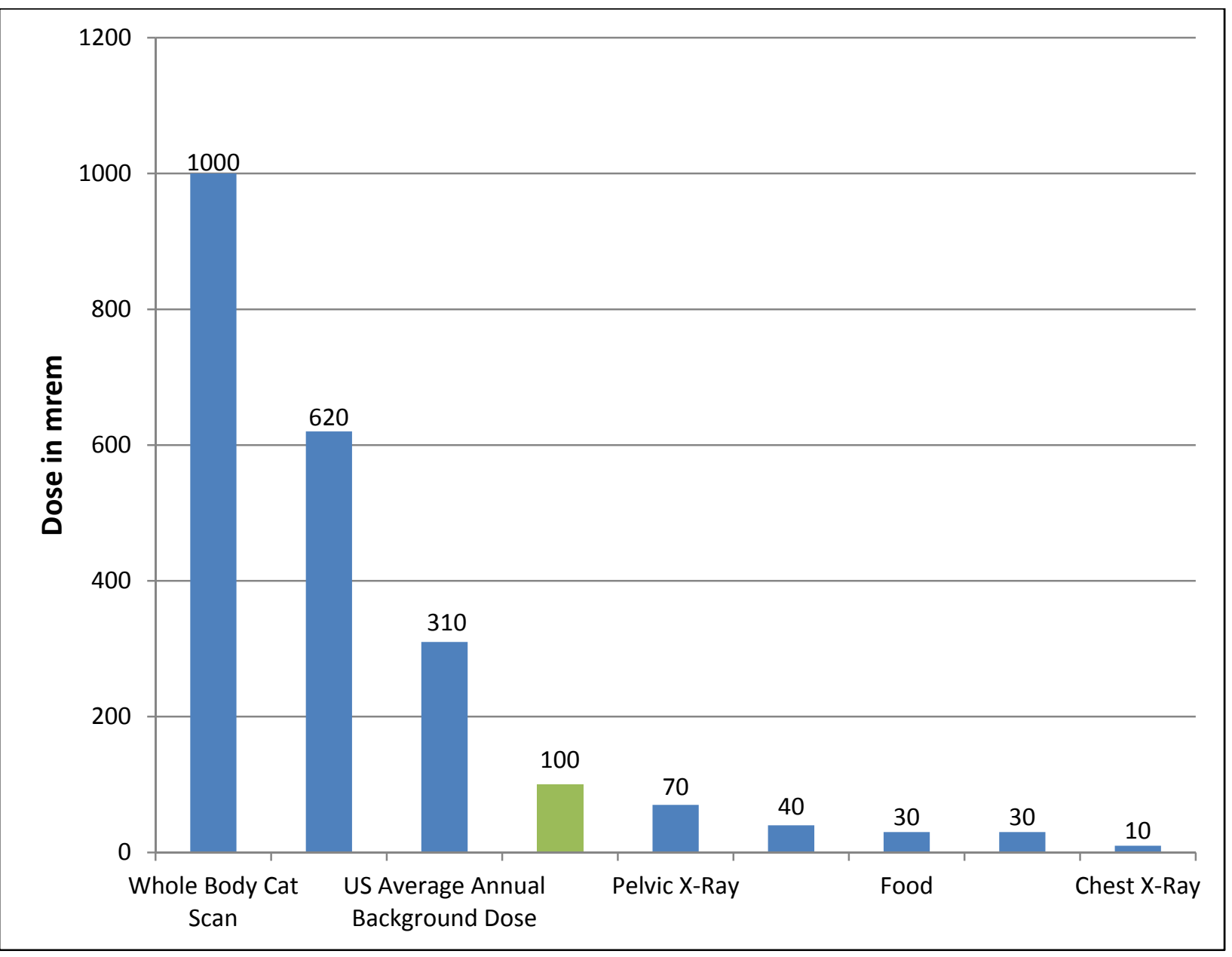

FIGURE 4.1 Typical Radiation Exposure Levels for Common Activities (Source: NRC 2014) 


\subsection{DESCRIPTION OF RISK ASSESSMENT METHODOLOGY}

Pathway analysis computer codes were used to estimate the dose to both workers and members of the general public. These codes included RESRAD-BUILD, RADTRAN, TSDDOSE, and RESRAD. References for each of these codes are provided in the following sections.

\subsubsection{Methodology for Operational Phase Scenarios}

The methodology for operational phase scenarios is discussed in Section 4.2.1.1 for well site operations, in Section 4.2.1.2 for transportation, and in Section 4.2.1.3 for landfills. As discussed in Section 3.2.1, the radiological impacts on both the workers who participate in these operations and members of the general public were considered.

\subsubsection{Well Site Operations}

Worker and public doses from well site operations were estimated using the RESRADBUILD computer code developed at Argonne (Yu et al. 2003). For more information about the RESRAD-BUILD code and access to the code, see https://web.evs.anl.gov/resrad/ home2/Build.cfm.

The RESRAD-BUILD computer code is a pathway analysis model to evaluate the potential radiation dose incurred by an individual who works or lives in a building contaminated with radioactive material. The code can model point, line, area, and volume source geometries. The contamination could be (1) on the surface; (2) within the material, such as pipes, or wires; or (3) accumulated inside the object or on objects, such as filter cake and filter socks. The volume source can be composed of up to five layers of different materials. A shielding material between the source and receptor can be specified for external gamma dose calculations. Seven exposure pathways are included in the code: (1) direct external exposure, (2) external exposure from the deposited material on the floor, (3) air submersion, (4) inhalation of airborne radioactive particulates, (5) inhalation of indoor radon progeny, (6) direct ingestion, and (7) ingestion of deposited material.

\subsubsection{Transportation}

The transportation risk assessment considered human health risks from routine transport (normal, incident-free conditions) of TENORM and from potential accidents. In both cases, risks associated with the nature of the cargo itself and those related to the transportation vehicle (regardless of type of cargo) were considered. For routine transportation, the cargo-related risk results from the potential exposure to low levels of external radiation near a loaded shipment of TENORM, and vehicle-related risks are from potential exposure to increased vehicular emissions. For accidents, the cargo-related risk lies in the potential release and dispersal of TENORM into the environment during an accident and the subsequent exposure to the nearby population through multiple exposure pathways, such as exposure to contaminated soil, 
inhalation, or the ingestion of contaminated food. Vehicle-related accidents result in fatalities caused by physical trauma unrelated to the cargo.

The RADTRAN computer code, developed by Sandia National Laboratories, was used for the transportation risk assessment (Weiner et al. 2013). The code has been used extensively for transportation risk assessments since it was originally issued in the late 1970s as RADTRAN (RADTRAN 1) and has been reviewed and updated periodically. The code calculates the MEI doses as well as population doses. For more information about the RADTRAN code, see https://rsicc.ornl.gov/codes/ccc/ccc5/ccc-508.html.

\subsubsection{Landfill Operations}

The TSD-DOSE computer code, developed by Argonne with support from the U.S. Department of Energy (DOE), estimates radiological doses to workers and members of the public from operations at a treatment, storage, and disposal (TSD) facility (Pfingston et al. 1998). The estimated radiological doses address seven distinct reference operations, and the default parameters used in TSD-DOSE for the reference operations were developed based on data collected from detailed dose assessments for eight different TSD facilities. Each of the reference operations can be toggled on or off, and the parameter values defining the reference operations can be modified to model specific activities at different TSD facilities. The seven reference operations modeled with TSD-DOSE include:

1. Transport to a TSD facility,

2. Receiving and sampling,

3. Storage,

4. Incineration,

5. Disposal at an on-site landfill,

6. Transport to an off-site landfill, and

7. Incinerator maintenance.

\subsubsection{Methodology for Future-Use Scenarios}

The RESRAD computer code, developed by Argonne under DOE sponsorship, is used to evaluate radioactively contaminated sites (Yu et al. 2001). For more information about the RESRAD code and access to the code, see https://web.evs.anl.gov/resrad/home2/resrad.cfm. RESRAD implements the methodology described in DOE's manual for developing residual radioactive material guidelines. The code estimates the time-integrated annual dose and excess lifetime cancer risk to a chronically exposed individual at a site with radiological contamination 
(DOE 1990). The calculated total dose, referred to as the total effective dose equivalent (TEDE), is the sum of the EDE from external radiation plus the 50-year CEDE from internal radiation. The RESRAD code focuses on radioactive contaminants initially in soil and their subsequent transport in air, water, and biological media to individual on-site receptors. Nine exposure pathways are considered in RESRAD: direct exposure, inhalation of particulates and radon, and ingestion of plant foods, meat, milk, aquatic foods, water, and soil. The RESRAD computer code was used in conjunction with the hydrologic models described in Section 4.2 to estimate radiological doses associated with the ingestion and general use of groundwater potentially contaminated with TENORM.

\subsubsection{Calculating Maximum Allowable TENORM Concentrations for Landfill Disposal}

Previous analyses demonstrated that the highest potential doses associated with landfill disposal are associated with future-use scenarios such as those discussed in Section 3.2.2 (Smith et al. 1999). In those analyses, the future-use scenarios imposed the most stringent constraints (i.e., the lowest radionuclide concentrations) in terms of the amount of TENORM that could be safely disposed of in the landfill. As a result, in this study, initially the risk assessments for future-use scenarios were conducted first to back-calculate the maximum average concentration of TENORM that could be accepted at a landfill without exceeding the regulatory dose limit of $100 \mathrm{mrem} / \mathrm{yr}$ for any one of the future-use receptors. These maximum concentrations were then used to evaluate potential doses to workers and the general public during the landfill operations phase and to receptors associated with transportation of the TENORM wastes to the landfill. However, estimates of potential doses associated with some landfill operations scenarios (the waste handling and placement workers) using the maximum concentrations from the future-use scenario analyses resulted in unacceptably high doses. As a result, additional calculations were run for those scenarios to derive the maximum allowable TENORM concentrations for landfill disposal required to limit dose to these workers to $100 \mathrm{mrem} / \mathrm{yr}$.

\subsection{HYDROLOGIC MODELING}

The objective of the hydrological analyses was to provide information on the concentrations of TENORM radioisotopes of concern in groundwater as functions of time and location. This information was then used to assess human health risk. Future-use scenarios were considered by using appropriate time frames for the analyses. Because the operational phase is short compared with likely transport times for radionuclides to reach the location of potential onand off-site receptor wells, operational impacts from groundwater resources are not expected to occur. Future-use scenarios were evaluated to a time horizon of 10,000 years for both on- and off-site receptors. 


\subsubsection{Landfill Hydrologic Modeling}

Infiltration and percolation for two landfill types were analyzed with the Hydrologic Evaluation of Landfill Performance (HELP) model (Schroeder et al. 1994a,b). The HELP model is considered quasi-two-dimensional because it couples one-dimensional vertical percolation and one-dimensional lateral drainage and surface runoff. HELP can be used to model the various layers of a landfill system, including vertical percolation through soil, compacted barrier soil, or waste; lateral drainage through sandy drainage layers with or without leachate collection; and vertical percolation through geomembranes of different materials and quality. It is a generally accepted tool for estimating leachate rates and volumes. Management of data input and analyses of the model's output were facilitated using Visual HELP (Waterloo Hydrologic, Inc. 2000).

The HELP model has the capability to generate statistically supported weather data (monthly precipitation, monthly temperature, quarterly relative humidity, evaporative zone depth, growing season span, and average wind speed) for a user-defined duration of years. For this study, data from Bismarck, North Dakota, were used. Bismarck is located roughly 100 to $300 \mathrm{~km}$ (60 to $200 \mathrm{mi}$ ) southeast of the main oil and gas activity (Figure 3.1) and is assumed to have similar weather to the study area. To be conservative, the evaporative depth was set to a small value ( $25 \mathrm{~cm}$ or $10 \mathrm{in}$.); the completed landfill was assumed to be treeless (leaf area index of zero); and the grass cover of the completed landfill was set to a status of a fair condition. The synthetic weather generator was run for 100 years to provide a large amount of information on the variability of the input to the modeled landfill.

As detailed in Section 3.1, two landfill types were considered in the analyses. The model layers of the Special Waste Landfill and Industrial Waste Landfill are defined in Appendix C (Tables C.1 and C.2, respectively).

The slope assigned to LCS piping and sloped layers was $1.5 \%$, while the maximum length of a slope was set to $30 \mathrm{~m}$ (98 ft), which represents the length of a surface sloped toward an LCS pipe. This slope value is considered a conservative assumption because it allows for larger head buildup in drainage layers.

Porosity, field capacity, wilting point, and saturated hydraulic conductivity of various layers in the HELP model were assumed to be the default values for each specific material type in the HELP model, with the following exceptions. The porosity of sand drainage layers was reduced from the default value to 0.22 to be conservative. The saturated hydraulic conductivity of the sand drainage layers was set to $1 \times 10^{-3} \mathrm{~cm} / \mathrm{s}\left(3.3 \times 10^{-5} \mathrm{ft} / \mathrm{s}\right)$, while the saturated hydraulic conductivity of barrier layers was set to a maximum of $1 \times 10^{-7} \mathrm{~cm} / \mathrm{s}\left(3 \times 10^{-9} \mathrm{ft} / \mathrm{s}\right)$, per North Dakota regulatory requirements (NDAC; Chapter 33-20-07.1 and Chapter 33-20-10) (see Appendix C).

Synthetic liner material is required by North Dakota regulations. In this study, the geomembrane material was assumed to be HDPE, which is included in the HELP material options. The number of pinholes was set to 25 per ha (10 per acre), the number of material defects was set to 4 per ha (1.6 per acre), and the installation placement quality was conservatively set to HELP's default "poor" condition. 
The landfill in the HELP model was set to be 19 ha (46 acres), the average size of the landfills permitted in North Dakota in 2013 (Table 3.1). Based on the waste areas and total waste volumes of the landfills permitted in 2013, the average waste thickness, including daily and intermediate soil cover, was $38 \mathrm{~m}(125 \mathrm{ft})$. This value was used in the HELP assessment of closed landfills, while half of this thickness was used as input to assess the open, operating landfill condition.

In each case, an additional HELP model layer was included at the bottom of the modela natural soil representing a thickness of unsaturated soil above the water table. This material was set to a thickness of $20 \mathrm{~m}(66 \mathrm{ft})$ and was conservatively assumed to be loamy sand. The purpose of this extra layer was to evaluate the rate of movement of leachate through this unsaturated zone.

For each of the two landfills, five cases were evaluated with the HELP model:

- Operational phase. To assess the operational phase with an open (active) landfill cell, the waste, including daily and intermediate soil cover, was assumed to be half of the total thickness, or $19 \mathrm{~m}$ (62.5 ft). Daily or intermediate cover exposed at the surface was assumed to have similar infiltration characteristics as the underlying waste. The LCS is functional.

- Post-closure phase. In this case, the landfill cap is completed. The geomembrane liners and the LCS are functional.

- Post-closure phase-no geomembranes. The geomembrane of the Special Waste Landfill's synthetic liner and the geomembrane of the Industrial Waste Landfill's cap and synthetic liners are assumed to have decomposed and are absent from the HELP model. The LCS is functional.

- Post-closure phase-no geomembranes or LCS. The synthetic liners are assumed to have decomposed, and the LCS no longer functions.

- Sensitivity of post-closure phase. In this variation of the post-closure phase, the LCS continues to operate and the HDPE liners are present; however, the quality of the synthetic liner material is worse. The number of pinholes is increased to 125 per ha ( 51 per acre), the number of material defects is doubled to 8 per ha ( 3.3 per acre), and the installation placement quality is reduced to HELP's "bad" condition.

\subsubsection{Hydrogeological Setting of a Generic Landfill and Model Parameter Values}

North Dakota's surficial geology is dominated by glacial depositional processes, which have resulted in thick sequences of glacial drift in most areas. The drift is predominantly finegrained glacial till of low permeability. Relatively thin, discontinuous sand units may be present within the drift also. Review of hydrogeologic reports for six landfills in western North Dakota 
permitted in 2013 indicated consistency with this overall description. Fine-grained glacial tills dominate, with hydraulic conductivity values of $1 \times 10^{-6}$ to $1 \times 10^{-8} \mathrm{~cm} / \mathrm{s}\left(3 \times 10^{-8}\right.$ to $\left.3 \times 10^{-10} \mathrm{ft} / \mathrm{s}\right)($ Golder 2013; Wenck 2012a; Carlson McCain 2012; Barr 2013). Sandy zones are possible within the glacial drift sequence with hydraulic conductivity values ranging from $1 \times 10^{-3}$ to $1 \times 10^{-5} \mathrm{~cm} / \mathrm{s}\left(3 \times 10^{-5}\right.$ to $\left.3 \times 10^{-7} \mathrm{ft} / \mathrm{s}\right)($ Golder 2013; Wenck 2012a; Carlson McCain 2012; MWH 2012); however, these sandy units represent discontinuous, perched aquifers rather than important resources (Golder 2013; Wenck 2012b; Barr 2013). Barr (2013) described a conceptual site model consisting of perched groundwater that likely seeps slowly downward rather than spreading laterally. Some site investigations documented a deep confining clay with an upper surface at a depth of $18 \mathrm{~m}(60 \mathrm{ft}$ ) (Wenck 2012a). One study documented a regional bedrock aquifer groundwater flow system at a depth of $140 \mathrm{~m}(460 \mathrm{ft})$ or more (Barr 2013). Measured hydraulic gradients at the sites range from 0.003 to 0.03 .

Although geologic and hydrogeologic conditions vary spatially, based on review of the site-specific information, the hydrogeologic setting for a generic North Dakota landfill location is expected to include thick, fine-grained glacial till with minor sand and gravel units, and a regional bedrock aquifer at a significant depth. For the purpose of modeling to support decisionmaking regarding TENORM disposal in North Dakota, parameter values were assumed for a base case and for sensitivity cases, to evaluate the outcome from parameter values that would promote contaminant transport and concentrations.

\subsubsection{Unsaturated Zone Modeling}

Flow through the thick, unsaturated, natural soil beneath the landfill was evaluated using the HELP model. For the depth to groundwater below the landfilled waste, $20 \mathrm{~m}(66 \mathrm{ft}) \mathrm{was}$ assumed for the base case, although much larger depths to a practical aquifer are possible. To evaluate sensitivity, a depth to groundwater of only $5 \mathrm{~m}(16 \mathrm{ft})$ was also considered. In both of these cases, a localized sandy unit within the glacial drift was assumed to convey groundwater in an amount suitable for use by a nearby receptor. HELP modeling was used to estimate the rate of travel through this material. Based on the time of travel through the unsaturated zone, radioactive decay of ROCs was calculated. In a conservative aspect of the calculation, sorption during unsaturated zone transport was ignored.

\subsubsection{Groundwater Transport Modeling}

\subsubsection{The Distribution Coefficient and Retardation}

Sorption of a contaminant can occur on the solid portion of an aquifer. The distribution coefficient $\left(\mathrm{K}_{\mathrm{d}}\right)$ is the slope of the linear sorption isotherm, relating the ratio of the amount of a solute sorbed onto a solid to the concentration of the solute.

$$
K_{d}=C^{*} / C_{\text {solute }},
$$


where

$$
\begin{aligned}
& K_{d}=\text { distribution coefficient }\left(\mathrm{L}^{3} / \mathrm{M}\right), \\
& C^{*}=\text { sorbed concentration }(\mathrm{M} / \mathrm{M}) \text {, and } \\
& C_{\text {solute }}=\text { solute concentration }\left(\mathrm{M} / \mathrm{L}^{3}\right) .
\end{aligned}
$$

A higher $\mathrm{K}_{\mathrm{d}}$ value produces greater retardation in the movement of a contaminant. Retardation is the ratio of the rate of bulk groundwater flow to the rate of contaminant transport. The $\mathrm{K}_{\mathrm{d}}$ value affects the retardation, $R$, of the contaminant by the relationship

$$
R=1+\left(K_{d}\right)\left(B_{d}\right) / n
$$

where

$$
\begin{aligned}
& R=\text { retardation (unitless), } \\
& B_{d}=\text { bulk density }\left(\mathrm{M} / \mathrm{L}^{3}\right), \text { and } \\
& n=\text { porosity (unitless). }
\end{aligned}
$$

The contaminant transport approach relying on the use of the distribution coefficient, $\mathrm{K}_{\mathrm{d}}$, to model retardation is easily incorporated into equations supporting groundwater models. In reality, the $\mathrm{K}_{\mathrm{d}}$ approach works best for contaminants that sorb weakly to soil and aquifer materials, are present in low concentrations, do not precipitate, and where the ambient conditions such as $\mathrm{pH}$ and chemical concentrations do not vary significantly (Brady and Bethke 2000). However, for cationic heavy metals and radionuclides, the approach has shortcomings because of sorption and precipitation processes. Alternative approaches could rely on surface complexation theory (Bethke and Brady 2000) or non-linear isotherms.

In this study, the relatively simple $\mathrm{K}_{\mathrm{d}}$ approach was followed because of the following factors:

- TENORM radionuclide concentrations are expected to be low in the aquifer underlying the landfill;

- Calculated downgradient concentrations will be conservatively high given the typical $\mathrm{K}_{\mathrm{d}}$ results, compared with surface complexation results or laboratory or field observations;

- Additional conservatism can be incorporated when choosing a $K_{d}$ value; and

- Simplicity in implementation.

An analysis of literature values for $\mathrm{K}_{\mathrm{d}}$ is presented in Appendix D. The available information demonstrates a wide range of $\mathrm{K}_{d}$ values for each ROC. For radium and thorium, $\mathrm{K}_{\mathrm{d}}$ values of $100,1,000$, and $10,000 \mathrm{~mL} / \mathrm{g}$ are appropriate to evaluate the sensitivity of calculations to this parameter. For lead, $\mathrm{K}_{\mathrm{d}}$ values of 10,100 , and $1,000 \mathrm{~mL} / \mathrm{g}$ should be examined. 


\subsubsection{Dispersivity}

In contaminant transport modeling, the dispersivity parameter controls the spread of a plume. Longitudinal dispersivity has been shown to increase with increasing scale of observation (Gelhar et al. 1992). Analysis of data suggests a great deal of noise in the relationship and a dependence on the reliability of the estimate; however, a longitudinal dispersivity of roughly $1 / 10$ th the scale of the study area is suggested (Zheng and Bennett 1995). Transverse and vertical dispersivity are generally much lower than longitudinal and can be approximated as 1/10th and 1/100th, respectively, of the longitudinal dispersivity (Zheng and Bennett 1995).

\subsubsection{Groundwater Flow and Contaminant Transport Code Selection}

The Modular Three-Dimensional Finite-Difference Groundwater Flow Model (MODFLOW) (Harbaugh et al. 2000), the numerical model used the most by the U.S. Geological Survey for groundwater flow problems, was used in this study to estimate the flow of groundwater away from the water table directly beneath a landfill. MODFLOW (Harbaugh et al. 2000) simulates the steady-state or transient flow of groundwater in an irregularly shaped flow system in which aquifer layers can be confined, unconfined, or both confined and unconfined. Flow from external stresses, such as flow to wells, areal recharge, evapotranspiration, flow to drains, and flow through river beds, can be modeled. Hydraulic conductivities or transmissivities for any layer may vary spatially and be anisotropic, and the storage coefficient may be heterogeneous. Various boundary conditions may be simulated, including specified head, specified flux, and head-dependent flux.

The Modular 3-D Multi-Species Transport Model (MT3DMS) (Zheng and Wang 1999), a companion code of MODFLOW, was used to calculate the movement of dissolved constituents. MT3DMS (Zheng and Wang 1999) is a three-dimensional finite-difference computer model that can be used to simulate changes in concentrations of miscible contaminants in groundwater, considering such processes as advection, dispersion, diffusion, and some basic chemical reactions, with various types of boundary conditions and external sources or sinks. The chemical reactions included in MT3DMS include linear sorption and first-order decay. MT3DMS is used to calculate the concentrations of the contaminants of concern as functions of time at the locations of on- and off-site receptors. In this study, the leachate from the landfill was assumed to act as a continuous source of contamination to the aquifer. This is a reasonable assumption for Ra-226. A method by Baird et al. (1990), when applied with parameter estimates for this North Dakota study, suggested an annual leached fraction (LF) on the order of $1 \times 10^{-8}$, which supports a very long source. Concentrations of ROCs predicted by MT3DMS were used to

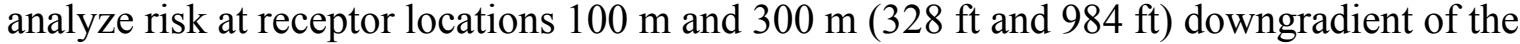
landfill for the on- and off-site receptors, respectively. Concentrations of the ROCs at the two receptor locations were calculated for a period of 10,000 years. These concentrations were used as input for risk assessment calculations. The parameters used for these calculations are summarized in Table 4.1. 
TABLE 4.1 Values Used To Model Radionuclide Concentrations in the Groundwater Downgradient of a Landfill

\begin{tabular}{|c|c|c|}
\hline Parameter & Base Case Value & Sensitivity Analysis Value(s) \\
\hline Distance to receptor & $300 \mathrm{~m}(984 \mathrm{ft})$ & $100 \mathrm{~m}(328 \mathrm{ft})$ \\
\hline $\mathrm{K}_{\mathrm{d}}$ & $\begin{array}{l}\text { 10,000 mL/g } \\
\text { (Ra-226, Ra-228, or Th-232) } \\
1,000 \mathrm{~mL} / \mathrm{g}(\mathrm{Pb}-210)\end{array}$ & $\begin{array}{l}1.000 \text { and } 100 \mathrm{~mL} / \mathrm{g} \\
\text { (Ra-226, } \mathrm{Ra}-228, \text { or Th-232) } \\
100 \text { and } 10 \mathrm{~mL} / \mathrm{g}(\mathrm{Pb}-210)\end{array}$ \\
\hline $\begin{array}{l}\text { Hydraulic conductivity of shallow } \\
\text { groundwater flow system }(\mathrm{K})\end{array}$ & $1 \times 10^{-4} \mathrm{~cm} / \mathrm{s}\left(3.3 \times 10^{-6} \mathrm{ft} / \mathrm{s}\right)$ & $1 \times 10^{-3} \mathrm{~cm} / \mathrm{s}\left(3.3 \times 10^{-5} \mathrm{ft} / \mathrm{s}\right)$ \\
\hline Longitudinal dispersivity & $30 \mathrm{~m}(98 \mathrm{ft})$ & $300 \mathrm{~m}(980 \mathrm{ft})$ \\
\hline Hydraulic gradient & 0.015 & 0.03 \\
\hline
\end{tabular}


This page intentionally left blank. 


\section{HYDROLOGICAL MODELING RESULTS}

This section presents the results of the hydrological modeling for transport of radionuclides through the landfill and below the landfill in both the unsaturated and saturated zones.

\subsection{LANDFILL HYDROLOGIC MODELING}

The HELP database's average annual precipitation data for Bismarck was $39 \mathrm{~cm}$ (15.4 in.). Figure 5.1 shows the synthetic weather generator's results for 100 years. The annual amount of evapotranspiration from model runs was slightly less than the precipitation amount, with much lower runoff and even lower infiltration.

The HELP model results for the various landfill scenarios show variability of annual percolation rates throughout the modeled 100-year time frame, but these results fluctuate around an annual average. Figures 5.1 through 5.3 illustrate, for example, the closed Industrial Waste Landfill results from the HELP model over a 100-year period for (1) precipitation, evapotranspiration, and runoff; (2) percolation through the cap's compacted soil and the upper geomembrane liner; and (3) percolation through the recompacted liner soil and the deep natural soil. The results show about $0.0013 \mathrm{~cm}(0.0005 \mathrm{in}$.) of leachate per year escaping from the bottom of the landfill. In a contrasting example, Figure 5.4 shows the percolation for a point in the future of an Industrial Waste Landfill when the geomembranes have decomposed and the LCS is inactive. In this case, $2 \mathrm{~cm}$ ( 0.8 in.) per year is passing through both the cap and the soil liner. The leachate percolating through the bottom of the deep natural soil begins to mimic the rate through the upper units after about 60 years, in dynamic equilibrium.

Table 5.1 presents the percolation rates associated with all tested scenarios. Closed landfills with operating LCSs reject almost all precipitation as a combination of evapotranspiration, runoff, and collected leachate, which allows very small amounts to percolate through the landfill liner system for both the Industrial and the Special Waste cases. North Dakota's rejection requirement is met for each case with an operating LCS except for the Industrial Waste Landfill sensitivity run (geomembranes with more pinholes, more defects, and worst placement quality), which fell slightly behind the required rejection rate due to the additional conservatism of the input parameters. For both the Industrial and Special Waste Landfills, the sensitivity analysis of the operating landfill (geomembranes with more pinholes, more defects, and worst placement quality) indicates percolation rates that are similar to those without any liner, thus demonstrating the importance of the geomembrane quality.

This study did not estimate the length of time for partial or complete decomposition of the landfill geomembranes to occur. The percolation rate calculated by the HELP model without geomembranes is a rate that is relevant to long-term analysis for groundwater modeling and, therefore, was used in this assessment. 


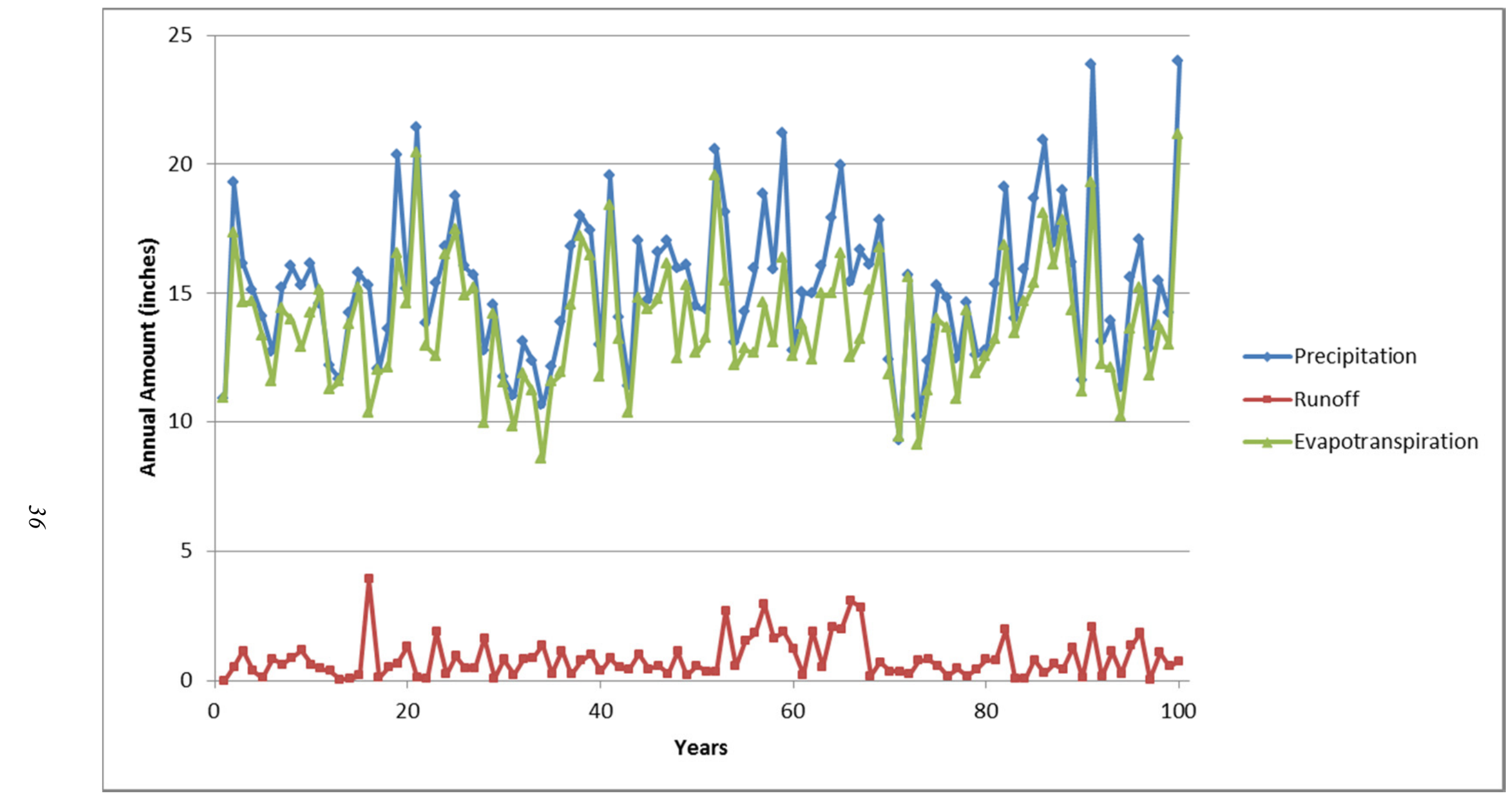

FIGURE 5.1 HELP Model Results for the Closed Industrial Waste Landfill for Precipitation, Evapotranspiration, and Runoff over 100 Years 


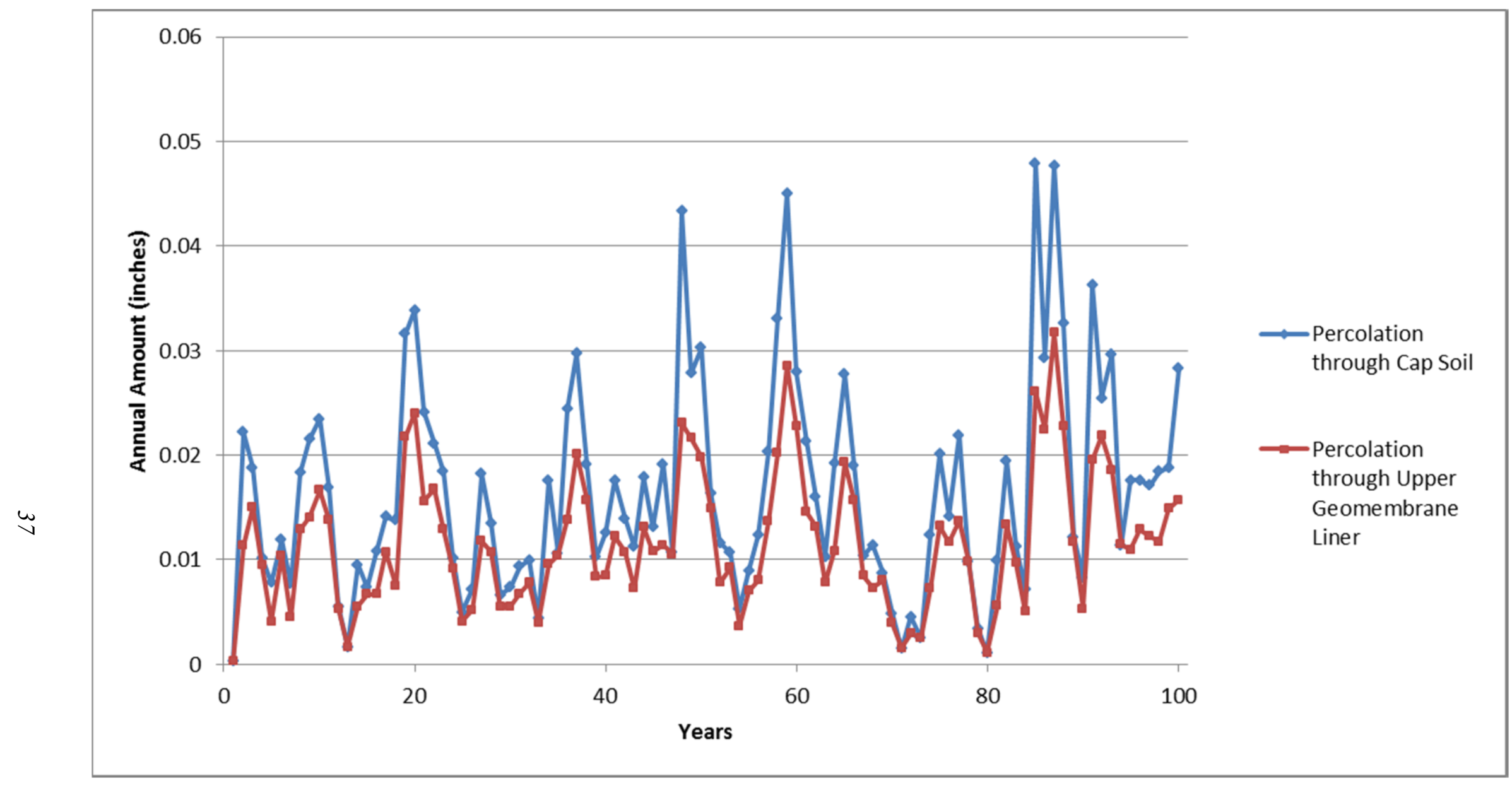

FIGURE 5.2 HELP Model Results for the Closed Industrial Waste Landfill for Percolation through the Compacted Soil of the Cap and through the Upper Geomembrane Liner over 100 Years 


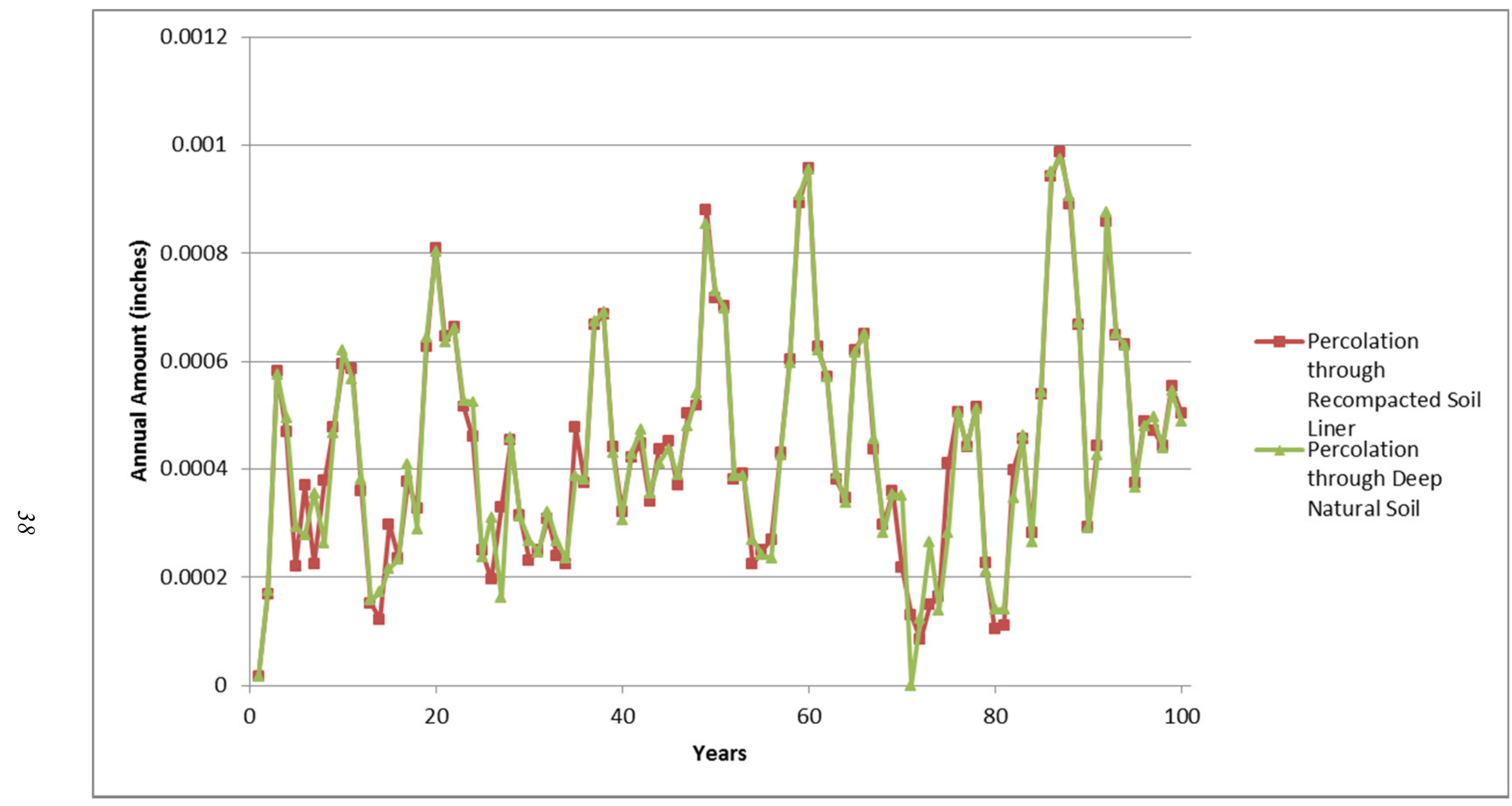

FIGURE 5.3 HELP Model Results for the Closed Industrial Waste Landfill for Percolation through the Recompacted Liner Soil and the Deep Natural Soil over 100 Years 


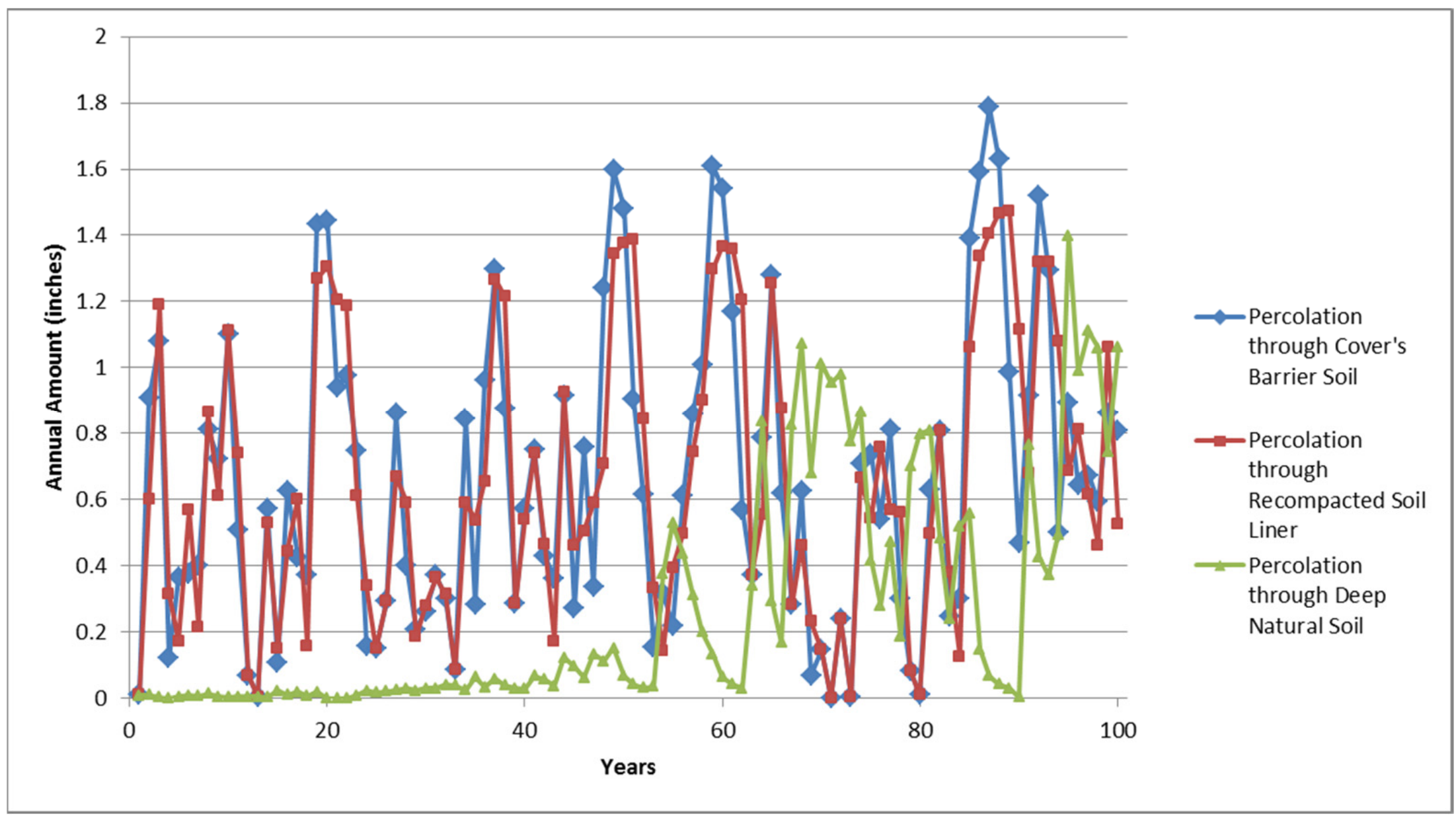

FIGURE 5.4 HELP Model Results for the Closed Industrial Waste Landfill with Decomposed Geomembranes and an Inactive LCS for Percolation through the Cover's Barrier Soil, the Recompacted Liner Soil, and the Deep Natural Soil over 100 Years 
TABLE 5.1 Summary of HELP-Model-Derived Percolation Results for Industrial and Special Waste Landfill Scenarios

\begin{tabular}{|c|c|c|c|c|c|c|}
\hline Case & Layer & $\begin{array}{l}\text { Average } \\
\text { Percolation } \\
\text { (in./yr) } \\
\end{array}$ & $\begin{array}{c}\% \\
\text { Rejected }^{\mathrm{a}} \\
\end{array}$ & $\begin{array}{c}\% \text { Required for } \\
\text { Post-Closure } \\
\text { With LCS } \\
\text { Operating } \\
\end{array}$ & $\begin{array}{l}\text { Average } \\
\text { Collected } \\
\text { Leachate } \\
(\mathrm{gal} / \mathrm{yr})^{\mathrm{b}}\end{array}$ & Notes $^{\mathrm{c}}$ \\
\hline \multirow{3}{*}{$\begin{array}{l}\text { Operating Industrial } \\
\text { Landfill, half the waste } \\
\text { thickness }\end{array}$} & Upper geomembrane liner & 0.5 & 96.75 & \multirow{3}{*}{97.00} & 624,505 & \\
\hline & Clay liner & 0.01 & 99.94 & & 12,490 & \\
\hline & Thick natural soil & 0.01 & 99.94 & & 12,490 & \\
\hline \multirow{4}{*}{$\begin{array}{l}\text { Closed Industrial } \\
\text { Landfill, good } \\
\text { membranes and LCS }\end{array}$} & Cap geomembrane & 0.025 & 99.84 & \multirow{4}{*}{99.99} & 31,225 & \\
\hline & Upper geomembrane liner & 0.015 & 99.90 & & 18,735 & \\
\hline & Clay liner & 0.0005 & 100.00 & & 625 & \\
\hline & Thick natural soil & 0.0005 & 100.00 & & 625 & \\
\hline \multirow{3}{*}{$\begin{array}{l}\text { Closed Industrial } \\
\text { Landfill, membranes } \\
\text { decomposed }\end{array}$} & Clay cap & 0.8 & 94.81 & & 999,208 & \\
\hline & Clay liner & 0.8 & 94.81 & & 999,208 & \\
\hline & Thick natural soil & 0.4 & 97.40 & & 499,604 & A \\
\hline \multirow{3}{*}{$\begin{array}{l}\text { Closed Industrial } \\
\text { Landfill, membranes } \\
\text { decomposed and LCS } \\
\text { no longer functioning }\end{array}$} & Clay cap & 0.8 & 94.81 & & 999,208 & \multirow[b]{3}{*}{$\mathrm{B}$} \\
\hline & Clay liner & 0.8 & 94.81 & & 999,208 & \\
\hline & Thick natural soil & 0.8 & 94.81 & & 999,208 & \\
\hline \multirow{4}{*}{$\begin{array}{l}\text { Operating Industrial } \\
\text { Landfill, sensitivity of } \\
\text { post-closure (worse } \\
\text { pinholes, defects, } \\
\text { placement quality) }\end{array}$} & Cap geomembrane & 0.7 & 95.45 & \multirow{4}{*}{97.00} & 874,307 & \multirow[b]{4}{*}{$\mathrm{B}$} \\
\hline & Upper geomembrane liner & 0.6 & 96.10 & & 749,406 & \\
\hline & Clay liner & 0.6 & 96.10 & & 749,406 & \\
\hline & Thick natural soil & 0.4 & 97.40 & & 499,604 & \\
\hline \multirow{2}{*}{$\begin{array}{l}\text { Operating Special } \\
\text { Landfill, half the waste } \\
\text { thickness }\end{array}$} & Clay liner & 0.025 & 99.84 & \multirow[t]{2}{*}{90.00} & 31,225 & \\
\hline & Thick natural soil & 0.012 & 99.92 & & 14,988 & \\
\hline \multirow{3}{*}{$\begin{array}{l}\text { Closed Special Landfill, } \\
\text { good membranes and } \\
\text { LCS }\end{array}$} & Cap barrier soil & 0.9 & 94.16 & \multirow{3}{*}{98.50} & $1,124,109$ & \\
\hline & Clay liner & 0.022 & 99.86 & & 27,478 & \\
\hline & Thick natural soil & 0.01 & 99.94 & & 12,490 & \\
\hline \multirow{3}{*}{$\begin{array}{l}\text { Closed Special Landfill, } \\
\text { membranes } \\
\text { decomposed }\end{array}$} & Cap barrier soil & 0.8 & 94.81 & & 999,208 & \multirow[b]{3}{*}{$\mathrm{B}$} \\
\hline & Clay liner & 0.8 & 94.81 & & 999,208 & \\
\hline & Thick natural soil & 0.8 & 94.81 & & 999,208 & \\
\hline \multirow{3}{*}{$\begin{array}{l}\text { Closed Special Landfill, } \\
\text { membranes } \\
\text { decomposed and LCS } \\
\text { no longer functioning }\end{array}$} & Cap barrier soil & 0.8 & 94.81 & & 999,208 & \multirow[b]{3}{*}{ B } \\
\hline & Clay liner & 0.8 & 94.81 & & 999,208 & \\
\hline & Thick natural soil & 0.8 & 94.81 & & 999,208 & \\
\hline \multirow{3}{*}{$\begin{array}{l}\text { Operating Special } \\
\text { Landfill, sensitivity of } \\
\text { post-closure (worse } \\
\text { pinholes, defects, } \\
\text { placement quality) }\end{array}$} & Cap barrier soil & 0.9 & 94.16 & \multirow[t]{3}{*}{90.00} & $1,124,109$ & \\
\hline & Clay liner & 0.8 & 94.81 & & 999,208 & \\
\hline & Thick natural soil & 0.8 & 94.81 & & 999,208 & \\
\hline
\end{tabular}

a Percentage rejected is in comparison to 15.4 in. of annual precipitation.

b Average collected leachate per year assumes an average landfill size of 46 acres.

c Note A: This percolation rate is still climbing after 100 years to reach a dynamic equilibrium of $0.8 \mathrm{in} . / \mathrm{yr}$.

Note B: Dynamic equilibrium achieved at about 60 years. 
A key finding of the HELP model analysis was the future leach rate when the geomembranes have decomposed and the LCS is inactive. For both the Industrial and Special Waste cases, the percolation rate through the clay liner below the waste was $2 \mathrm{~cm}(0.8 \mathrm{in}$.) per year. This same percolation rate is partially due to similarities in cap materials but mainly is a result of having the same requirements for recompacted clay below the waste. This is a significant finding for two reasons. First, it indicates the long-term future rate that leachate would pass through to the underlying natural soils and to the underlying aquifer. Second, despite differences in the requirements for landfill layers and their thicknesses and properties, both the Industrial and the Special Waste Landfills perform the same in terms of long-term future percolation.

\subsection{UNSATURATED ZONE FLOW AND TRANSPORT}

Transport in the unsaturated zone was approximated by incorporating an additional layer in the HELP model, as described in Section 4.3.1. This layer was a natural soil below the landfill liner system. It was conservatively assumed to be loamy sand so that it would have a moderately high permeability. Its thickness was assumed to be $20 \mathrm{~m}(66 \mathrm{ft})$.

The HELP modeling relied on default values for porosity, field capacity, wilting point, and saturated hydraulic conductivity for this natural soil; these values were considered suitable for the purpose of a generic estimate. Results suggested a breakthrough of landfill leachate at the bottom of the thick loamy sand at approximately 60 years. The HELP-model-derived unsaturated zone flow rate was therefore on the order of $0.34 \mathrm{~m}(1.1 \mathrm{ft})$ per year. Of the ROCs, only those with a short half-life (Pb-210 and Ra-228) could experience a significant loss of contaminant mass during this unsaturated zone transport. This is also the case if the unsaturated zone is assumed to be conservatively thin at $5 \mathrm{~m}(16 \mathrm{ft})$.

Transport through the unsaturated zone would allow ROCs to be subject to sorption and dispersion. As a conservative assumption, these processes were ignored in determining the concentration at the water table beneath the landfill. Only the $\mathrm{Pb}-210$ and $\mathrm{Ra}-228$ concentrations required adjustment due to decay. The activity concentration lost during unsaturated transport is related to the landfill concentration as:

water table concentration $=$ landfill concentration $* \mathrm{e}^{\text {decay constant } * \text { transport time }}$

\subsection{SATURATED ZONE FLOW AND TRANSPORT}

Calculation of lateral groundwater flow and transport begins with numerical modeling of

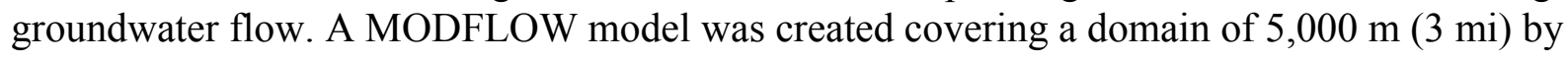
$1,000 \mathrm{~m}(0.6 \mathrm{mi})$ by $7 \mathrm{~m}(23 \mathrm{ft})$ in thickness. Figure 5.5 shows the upgradient end of the modeling domain, the landfill location, and the base case hydraulic heads. Grid cells were $10 \mathrm{~m}$

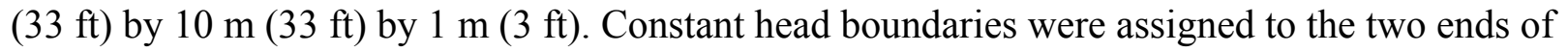
the domain in order to impose a uniform hydraulic gradient of 0.015 . The overall hydrogeologic setting of the recently permitted landfills described in Section 4.3.2 is a surficial 
Water Level (in meters

above arbitrary datum)

85
77
69
61
53
45
37
29
29
21
13
5
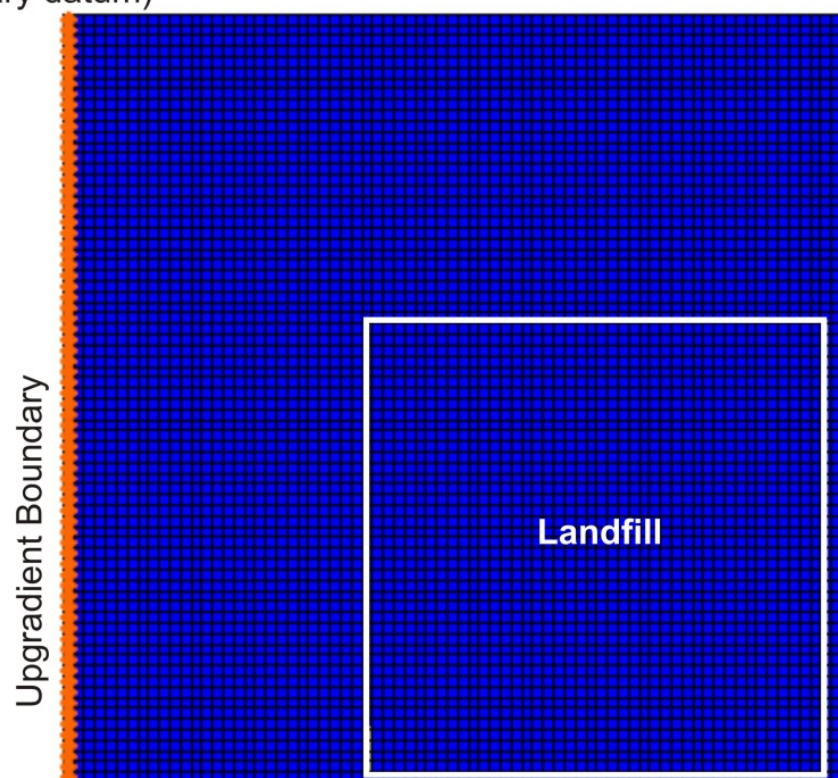

Receptors at $100 \mathrm{~m}$ and

300 m downgradient.
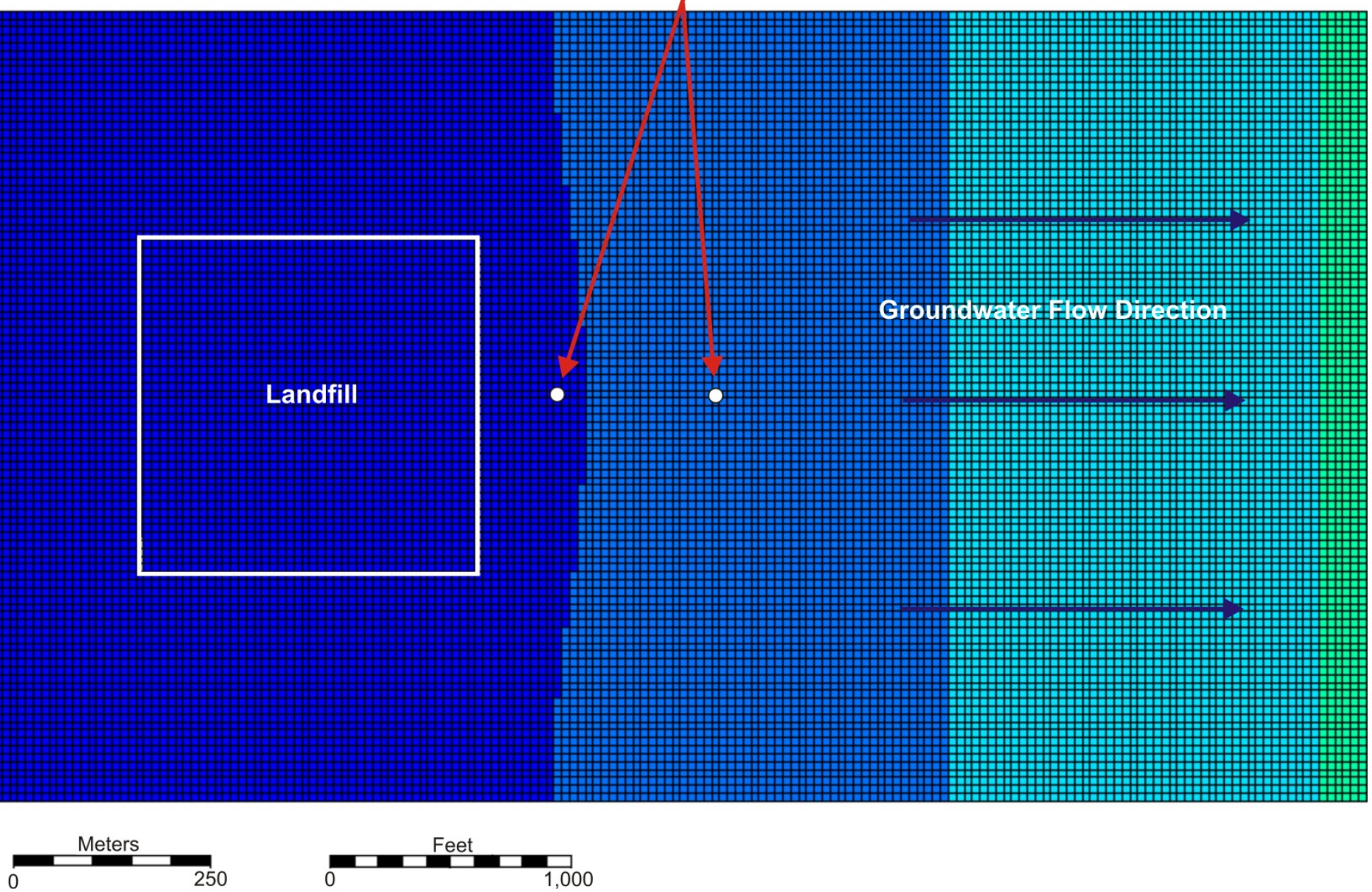

FIGURE 5.5 Hydraulic Heads, Landfill Location, and Receptor Locations at the Upgradient End of the Modeling Domain 
low-permeability glacial till above a confined aquifer. The modeled aquifer was therefore assumed to be a confined aquifer rather than an unconfined, surficial aquifer, as unconfined aquifers are less prevalent in western North Dakota, and landfills would be much less likely to be proposed or permitted in such a location. The hydraulic conductivity for the modeled aquifer was set to $1 \times 10^{-4} \mathrm{~cm} / \mathrm{s}\left(3 \times 10^{-6} \mathrm{ft} / \mathrm{s}\right)$. The ratio of horizontal to vertical hydraulic conductivity was set to 10 for all layers' cells. The generic landfill of 19 ha (46 acres) was modeled near the upgradient end of the domain, and recharge in this landfill footprint was $2 \mathrm{~cm} / \mathrm{yr}(0.8 \mathrm{in} . / \mathrm{yr})$, as discussed in Section 5.1. The hydraulic heads in the resulting flow field are illustrated in Figure 5.5, which also shows the landfill location and receptors located $100 \mathrm{~m}(328 \mathrm{ft})$ and $300 \mathrm{~m}$ (984 ft) downgradient of the landfill. A slight bowing of the equipotentials near the landfill is due to the recharge in the landfill footprint.

MT3DMS relies on the flow field calculated by MODFLOW. For this study, MT3DMS modeled the following transport processes: advection, dispersion, source/sink mixing, and chemical reaction, including sorption and first-order decay. Input to these packages included an effective porosity of 0.25 , a longitudinal dispersivity of $30 \mathrm{~m}(98 \mathrm{ft})$, a horizontal transverse dispersivity of $3 \mathrm{~m}(10 \mathrm{ft})$, a vertical transverse dispersivity of $0.3 \mathrm{~m}(1 \mathrm{ft})$, and bulk density of $1.8 \mathrm{~g} / \mathrm{cm}^{3}\left(112 \mathrm{lb} / \mathrm{ft}^{3}\right)$. For the modeling of sorption, the option selected was the linear isotherm.

The $\mathrm{K}_{\mathrm{d}}$ for the ROCs was set to mid-range values based on the literature to serve in base case scenarios, along with values one order of magnitude higher or lower to evaluate sensitivity (Table 4.1).

Rather than a half-life value, MT3DMS requires the first-order decay rate constant. These are presented in Table 5.2.

In MT3DMS, the contaminated flux to the aquifer was modeled as recharge, with a rate of $2 \mathrm{~cm}$ (0.8 in.) per year as discussed in Section 5.1. This rate assumes that the liners are decomposed, and is therefore a practical consideration for a long-term scenario. This recharge flux was modeled as entering the aquifer throughout the landfill footprint. Recharge was not modeled elsewhere; rather, the groundwater flow field was simply maintained at the prescribed gradient except for a slight perturbation at the landfill due to the recharge.

The concentration of each ROC in the recharge flux was given a value of unity (1), and the proportion of the concentration of unity was modeled at receptor locations $100 \mathrm{~m}(328 \mathrm{ft})$ and $300 \mathrm{~m}$ (984 ft) downgradient of the landfill footprint and along the centerline of the flow model.

TABLE 5.2 Half-life and Rate Constant Values for Radionuclides of Concern

\begin{tabular}{cccc}
\hline & & & \\
Radionuclide & Half-life $(\mathrm{yr})$ & Rate Constant $(1 / \mathrm{s})$ & Rate Constant $(1 / \mathrm{yr})$ \\
\hline & & & \\
$\mathrm{Pb}-210$ & 22.2 & $9.90 \times 10^{-10}$ & $3.12 \times 10^{-2}$ \\
$\mathrm{Ra}-226$ & 1,600 & $1.40 \times 10^{-11}$ & $4.33 \times 10^{-4}$ \\
$\mathrm{Ra}-228$ & 5.75 & $3.82 \times 10^{-9}$ & $1.21 \times 10^{-1}$ \\
$\mathrm{Th}-232$ & $1.40 \times 10^{10}$ & $1.57 \times 10^{-18}$ & $4.95 \times 10^{-11}$ \\
\hline
\end{tabular}


The base case scenario was tested for each ROC. In addition, the follwing cases were explored to evaluate the sensitivity of the calculation to reasonable changes in input parameter values:

- $\mathrm{K}_{\mathrm{d}}$ lower by a factor of 10 (more conservative),

- $\mathrm{K}_{\mathrm{d}}$ higher by a factor of 10 (less conservative),

- Dispersivities increased by a factor of 10 (more conservative),

- Hydraulic gradient increased by a factor of 2 (more conservative), and

- Hydraulic conductivity increased by a factor of 10 (more conservative).

A total of six MT3DMS runs were made to evaluate base case results and the five sensitivity scenarios listed above. Figure 5.6 shows the results for the base case values for the 100-m (328-ft) downgradient location. For all model runs, the $\mathrm{C} / \mathrm{Co}$ (ratio of downgradient groundwater concentration to leachate recharge concentration) was determined for 10,000 years to obtain information on the long-range behavior of the transport processes. The maximum $\mathrm{C} / \mathrm{Co}$ in each case was at the 10,000-year point; the values associated with each distance and scenario are presented in Table 5.3. Results for $\mathrm{C} / \mathrm{Co}$ of the ROCs at the downgradient receptor locations showed tremendous reduction from the input concentration due to retardation and decay processes, especially at the $300-\mathrm{m}$ (984 ft) distance. These maximum C/Co values were used as input in a spreadsheet of groundwater calculations. This spreadsheet was a means of calculating the full process from disposal concentration of TENORM in the landfill to downgradient groundwater concentrations for each ROC. The process included an initial assumption of unity for the disposal concentration of NORM (assumed to be the sorbed concentration), an appropriate three-order-of-magnitude range of in-landfill $\mathrm{K}_{\mathrm{d}}$ values as discussed in Section 4.3.4.1, decay in the unsaturated zone, determination of the landfill leachate concentration recharging the underlying aquifer, the MT3DMS-derived proportion of the concentrations of this leachate recharge reaching the receptors, and the concentration at the receptors. The receptor concentrations are thereby tied to the disposal concentrations of unity; changes in disposal concentration produced rapid results for the downgradient groundwater concentration. These results are presented in Appendix E for the 100-m (328 ft) and 300-m (984-ft) downgradient receptor locations, and for the base case 20-m (66-ft) thick unsaturated zone above the aquifer as well as the 5-m (16-ft) thick unsaturated zone. For each ROC, the maximum concentration among all tested sensitivity scenarios, including the most conservative in-landfill $\mathrm{K}_{\mathrm{d}}$ values, was used as input in risk assessment for future-use scenarios in Section 6.3.

\subsection{DISCUSSION OF RESULTS}

The literature-based $\mathrm{K}_{\mathrm{d}}$ values were a key item in this analysis. These values, which were selected based on available information from example sites, produced a large amount of retardation in the transport of dissolved-phase ROCs. The slow rate of transport, combined with radioactive decay, reduced the downgradient concentrations significantly. In the case of each 

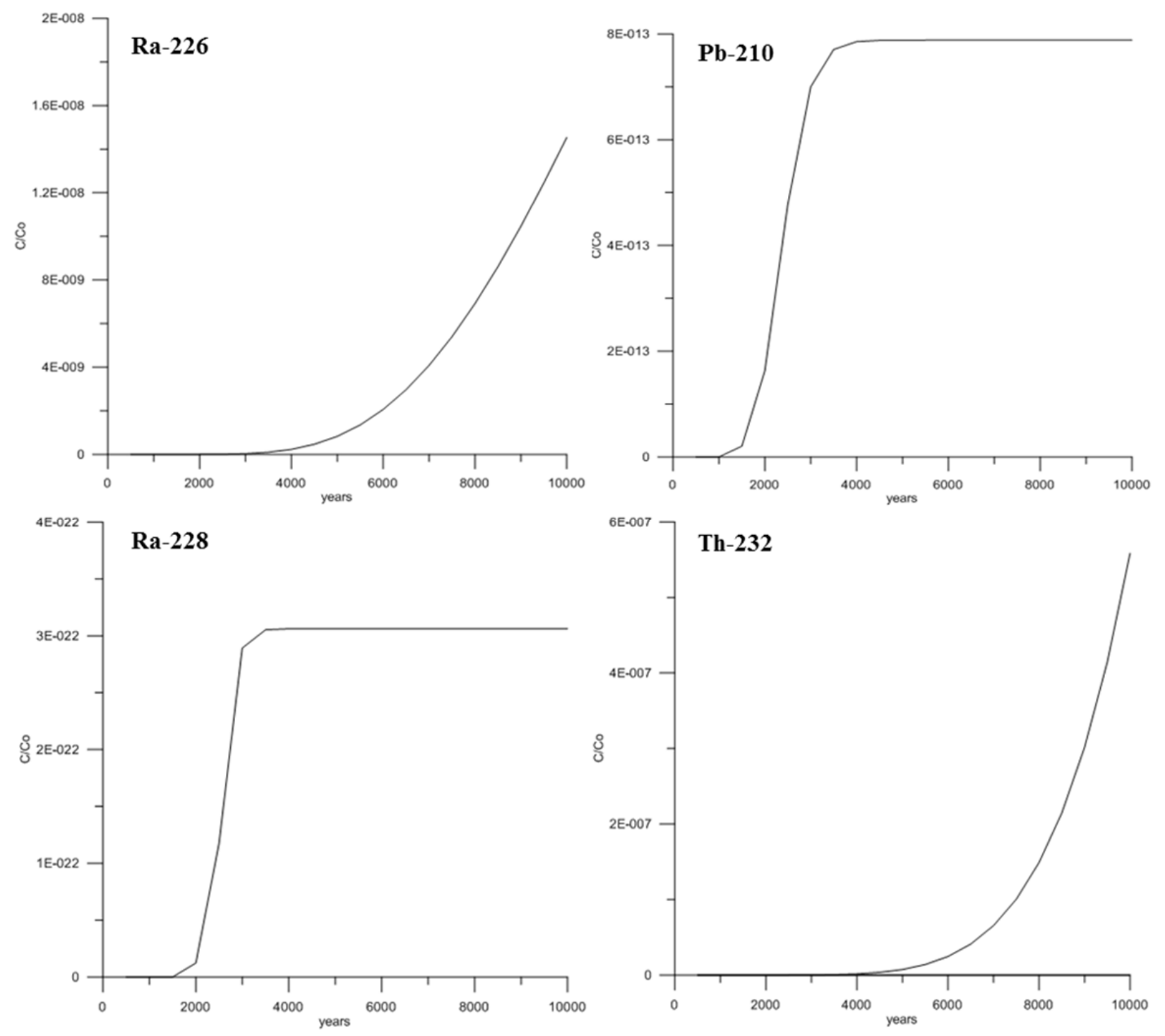

FIGURE 5.6 Base Case Results for C/Co at $100 \mathrm{~m} \mathrm{(328} \mathrm{ft)} \mathrm{(ratio} \mathrm{of} \mathrm{downgradient} \mathrm{concentration} \mathrm{to}$ leachate recharge concentration) over 10,000 Years for Each of the ROCs Modeled

ROC, the risk to a receptor is dependent on inherent properties of the ROC and concentration at the receptor, which is in turn dependent on the starting concentration determined for the landfill leachate reaching the water table.

The $\mathrm{C} / \mathrm{Co}$ concentrations calculated by MT3DMS at the two downgradient distances are conservative for use in risk assessment in that they do not provide estimates of activity concentrations that would occur in pumped groundwater. That is, a pumping well at these downgradient locations would create a cone of depression and have the possibility of drawing cleaner groundwater from both cross-gradient areas and from deeper portions of the aquifer. Thus, the activity concentrations of pumped groundwater could be lower than those calculated by MT3DMS. 
TABLE 5.3 Maximum Ratio of Downgradient Groundwater Concentration to Leachate Recharge Concentration over 10,000 Years

\begin{tabular}{|c|c|c|c|c|c|c|}
\hline \multirow[b]{2}{*}{$\mathrm{ROC}$} & \multicolumn{6}{|c|}{$\mathrm{C} / \mathrm{Co}$} \\
\hline & Base Case & Decreased $K_{d}$ & Increased $K_{d}$ & $\begin{array}{c}\text { Increased } \\
\text { Dispersivity }\end{array}$ & $\begin{array}{c}\text { Increased } \\
\text { Gradient }\end{array}$ & $\begin{array}{c}\text { Increased } \\
\text { Hydraulic } \\
\text { Conductivity }\end{array}$ \\
\hline \multicolumn{7}{|c|}{ Downgradient Distance of $100 \mathrm{~m}$} \\
\hline $\mathrm{Pb}-210$ & $7.88 \times 10^{-13}$ & $2.89 \times 10^{-7}$ & $6.14 \times 10^{-19}$ & $1.05 \times 10^{-9}$ & $1.27 \times 10^{-11}$ & $1.34 \times 10^{-7}$ \\
\hline Ra-226 & $1.45 \times 10^{-08}$ & $3.69 \times 10^{-7}$ & $9.64 \times 10^{-14}$ & $6.53 \times 10^{-6}$ & $2.05 \times 10^{-7}$ & $1.30 \times 10^{-4}$ \\
\hline $\mathrm{Ra}-228$ & $3.06 \times 10^{-22}$ & $1.92 \times 10^{-16}$ & $4.57 \times 10^{-30}$ & $1.61 \times 10^{-20}$ & $4.68 \times 10^{-21}$ & $1.59 \times 10^{-16}$ \\
\hline Th-232 & $5.59 \times 10^{-7}$ & $5.59 \times 10^{-7}$ & $5.59 \times 10^{-7}$ & $1.81 \times 10^{-4}$ & $6.65 \times 10^{-6}$ & $1.97 \times 10^{-3}$ \\
\hline \multicolumn{7}{|c|}{ Downgradient Distance of $300 \mathrm{~m}$} \\
\hline $\mathrm{Pb}-210$ & $3.47 \times 10^{-32}$ & $5.26 \times 10^{-17}$ & 0 & $2.92 \times 10^{-22}$ & $3.09 \times 10^{-28}$ & $1.96 \times 10^{-15}$ \\
\hline $\mathrm{Ra}-226$ & $3.53 \times 10^{-25}$ & $3.64 \times 10^{-23}$ & $5.66 \times 10^{-35}$ & $1.01 \times 10^{-13}$ & $2.60 \times 10^{-20}$ & $2.09 \times 10^{-8}$ \\
\hline Ra-228 & 0 & 0 & 0 & 0 & 0 & 0 \\
\hline Th-232 & $6.50 \times 10^{-23}$ & $6.50 \times 10^{-23}$ & $6.50 \times 10^{-23}$ & $3.88 \times 10^{-11}$ & $2.40 \times 10^{-18}$ & $9.75 \times 10^{-7}$ \\
\hline
\end{tabular}

The downgradient C/Co values of most ROCs showed little sensitivity to the thickness of the unsaturated natural soil between the landfill and the water table. For the $100-\mathrm{m}(328-\mathrm{ft})$ downgradient receptor location, the thin $(5 \mathrm{~m}$ or $16 \mathrm{ft}$ ) unsaturated zone resulted in a $\mathrm{C} / \mathrm{Co}$ 4 times greater for $\mathrm{Pb}-210$ and more than 200 times greater for $\mathrm{Ra}-228$. This effect is due to the relatively short half-lives for these ROCs. The other ROCs at $100 \mathrm{~m}(328 \mathrm{ft})$, and all four ROCs at $300 \mathrm{~m}(984 \mathrm{ft})$, had no difference in the $\mathrm{C} / \mathrm{Co}$ values when the thin unsaturated zone was assumed. 


\section{DOSE AND RISK ASSESSMENT RESULTS}

This section presents the results of the radiological dose and risk assessments. The assessment considered the potential doses and risks from latent fatal cancers associated with the several operational phase scenarios and several future-use scenarios that considered the potential doses and cancer risks to different hypothetical receptors after the landfill operations were completed. Descriptions of each scenario are presented in Section 3.2, and information about values defining each scenario is presented in Appendix B.

For the well site operations scenarios and the public exposures to improperly managed filter socks and proppants, potential doses and risks were presented for wastes assuming the average and maximum radionuclide concentrations as presented in Table 2.1.

As discussed in Section 4.2.3, the future-use scenario analyses were used to initially estimate the allowable radionuclide concentrations that could be safely disposed of in landfills on the basis that previous analyses of landfill disposal had indicated that future-use scenarios were the constraining scenarios. These concentrations were further adjusted to ensure that all workers and the general public did not receive unacceptably high doses during the operational phase of the landfill.

The results of the dose and risk assessments are presented in the following sequence: well site operational scenarios, including accidental public exposure to improperly managed filter socks and proppants; future-use landfill scenarios; transportation scenarios; and landfill operational scenarios.

\subsection{WELL SITE OPERATIONAL PHASE SCENARIOS}

For the well site operations and public exposure scenarios, doses were calculated using the average and maximum concentrations detected in each waste stream in North Dakota (see Table 2.1). Table 6.1 lists the waste stream used in different exposure scenarios.

\subsubsection{Radiological Doses for Well Site Workers}

It was assumed that well site workers are involved in mixing hydraulic fracturing fluid and produced water filtration activities. The assumptions and input parameters used to model well site worker scenarios are discussed in Section 3.2.1.1 and are listed in Table B.1 in Appendix B, respectively. Because of the large degree of uncertainty related to the radionuclide source term concentrations, two sets of dose assessments were performed. One set of dose assessment used the average concentration and the other set used the maximum radionuclide concentrations. Tables 6.2 and 6.3 list the estimated maximum dose rate for different well site operations using average and maximum waste stream concentrations, respectively, for the exposure pathways considered to be viable. 


\section{TABLE 6.1 Waste Streams Used in Evaluating Radiation Dose in Different Worker and Public Scenarios from Well Site Operations}

\begin{tabular}{ll}
\hline \multicolumn{1}{c}{ Scenario } & \multicolumn{1}{c}{ Waste Stream } \\
\hline $\begin{array}{l}\text { Well pad workers } \\
\text { Mixing hydraulic fracturing fluid } \\
\text { Produced water filtration }\end{array}$ & $\begin{array}{l}\text { Proppant } \\
\text { Filter cake and filter socks }\end{array}$ \\
$\begin{array}{l}\text { Equipment cleaning workers } \\
\text { Pipe cleaning } \\
\text { Storage tank cleaning }\end{array}$ & Scale \\
Gas processing & Sludge \\
& Pb-210 film \\
Sludge treatment workers & \\
Sludge treatment & Sludge \\
& \\
General public & \\
Filter socks used a toy & \\
Filter socks dumped in a dumpster & Filter socks \\
Illegal dumping of proppant on a field & Proppant \\
\hline
\end{tabular}

TABLE 6.2 Estimated Maximum Dose Rate (mrem/yr) for Different Well Site Operations Using Average Radionuclide Concentration

\begin{tabular}{|c|c|c|c|c|}
\hline Operations & Exposure Source & $\begin{array}{l}\text { Direct External } \\
\text { Exposure }\end{array}$ & Ingestion & $\begin{array}{c}\text { Total Dose } \\
\text { Rate (mrem/yr) }\end{array}$ \\
\hline Mixing hydraulic fracturing fluid & Proppant & 20 & $\mathrm{NA}^{\mathrm{a}}$ & 20 \\
\hline Produced water filtration & $\begin{array}{l}\text { Filter socks } \\
\text { Filter cake }\end{array}$ & 0.031 & 0.44 & 0.47 \\
\hline Pipe cleaning & Scale & 14 & NA & 14 \\
\hline Storage tank cleaning & Sludge & 3.8 & NA & 3.8 \\
\hline Equipment cleaning at gas processing & $\mathrm{Pb}-210$ film & 0.0003 & NA & 0.0003 \\
\hline Sludge treatment workers & Sludge & 1.6 & NA & 1.6 \\
\hline
\end{tabular}

a $\quad \mathrm{NA}=$ not applicable. 
TABLE 6.3 Estimated Maximum Dose Rate (mrem/yr) for Different Well Site Operations Using Maximum Radionuclide Concentration

\begin{tabular}{llccc}
\hline \multicolumn{1}{c}{ Operations } & $\begin{array}{c}\text { Exposure } \\
\text { Source }\end{array}$ & $\begin{array}{c}\text { Direct } \\
\text { External } \\
\text { Exposure }\end{array}$ & $\begin{array}{c}\text { Total Dose } \\
\text { Ingestion }\end{array}$ & $\begin{array}{c}\text { Rate } \\
\text { (mrem/yr) }\end{array}$ \\
\hline Mixing hydraulic fracturing fluid & Proppant & 23 & $\mathrm{NA}^{\mathrm{a}}$ & 23 \\
Produced water filtration & $\begin{array}{l}\text { Filter socks } \\
\text { Pipe cleaning }\end{array}$ & 0.36 & 1.8 & 2.2 \\
Storage tank cleaning & Filter cake & & & \\
Equipment cleaning at gas processing & Scale & 130 & NA & 130 \\
Sludge treatment workers & Sludge & 70 & NA & 70 \\
& Pb-210 film & 0.012 & NA & 0.012 \\
& Sludge & 30 & NA & 30 \\
\hline
\end{tabular}

a $\quad \mathrm{NA}=$ not applicable.

For all well site worker exposures, except the produce water filtration worker, it was assumed that PPE (respirators, eye protection, and gloves) would be worn. Assuming the average radionuclide concentrations in the TENORM waste streams, the highest potential dose, calculated for the mixing hydraulic fracturing fluid worker is $20 \mathrm{mrem} / \mathrm{yr}$; all other doses are well below this level. The 20-mrem/yr dose is below the recommended $100-\mathrm{mrem} / \mathrm{yr}$ dose limit (ICRP 1991). Assuming the maximum radionuclide concentration, the dose for the pipe cleaning worker is $130 \mathrm{mrem} / \mathrm{yr}$, and the dose for the storage tank cleaning worker is $70 \mathrm{mrem} / \mathrm{yr}$; other doses are considerably lower. These potentially high doses to the pipe and storage tank cleaning workers are based on the assumption that the workers perform this activity for 2,000 and $100 \mathrm{~h} / \mathrm{yr}$, respectively. Doses to these individuals could be reduced by limiting the annual exposures and splitting the task among multiple workers, if needed. The main contributors to dose for the well site worker scenarios are Ra-226 and Ra-228; the exception is for the worker cleaning equipment at a gas processing facility for whom only $\mathrm{Pb}-210$ is a ROC.

\subsubsection{Parameter Sensitivity Analyses for Well Site Operation Scenarios}

For the well site operation scenarios, dose was mostly from direct external exposure, and for the produced water filtration worker, from the ingestion pathways. For external exposure pathways, the sensitive parameters are exposure distance, source thickness, and shield thickness. For conducting sensitivity analysis, the parameter values were reduced (low end) and increased (high end) by a factor of 2 from the base case. For the worker using PPE while cleaning equipment at the gas processing facility, sensitivity analysis was not performed because the dose at the base case is very small. Table 6.4 lists the results of the sensitivity analysis, based on average radionuclide concentrations in the TENORM wastes.

For the hydraulic fracturing fluid mixing worker scenario, the sensitivity analyses were conducted on exposure distance using values of $0.5,1$, and $2 \mathrm{~m}(1.6,3.3$, and $6.6 \mathrm{ft})$ and on 
TABLE 6.4 Sensitivity Analyses for Well Site Operations Assuming Average Radionuclide Concentrations in the TENORM Wastes ${ }^{\mathrm{a}}$

\begin{tabular}{|c|c|c|c|c|c|c|c|}
\hline \multirow[b]{2}{*}{ Operations } & \multirow{2}{*}{$\begin{array}{c}\text { Base Case } \\
\text { Dose } \\
\text { (mrem/yr) }\end{array}$} & \multicolumn{2}{|c|}{$\begin{array}{c}\text { Sensitivity for } \\
\text { Receptor Distance }\end{array}$} & \multicolumn{2}{|c|}{$\begin{array}{c}\text { Sensitivity for } \\
\text { Shielding Thickness }\end{array}$} & \multicolumn{2}{|c|}{$\begin{array}{c}\text { Sensitivity for Source } \\
\text { Thickness }\end{array}$} \\
\hline & & $\begin{array}{l}\text { Low End } \\
(\mathrm{mrem} / \mathrm{yr})\end{array}$ & $\begin{array}{l}\text { High End } \\
(\mathrm{mrem} / \mathrm{yr})\end{array}$ & $\begin{array}{l}\text { Low End } \\
(\mathrm{mrem} / \mathrm{yr})\end{array}$ & $\begin{array}{l}\text { High End } \\
(\mathrm{mrem} / \mathrm{yr})\end{array}$ & $\begin{array}{l}\text { Low End } \\
(\mathrm{mrem} / \mathrm{yr})\end{array}$ & $\begin{array}{l}\text { High End } \\
(\mathrm{mrem} / \mathrm{yr})\end{array}$ \\
\hline Mixing hydraulic fracturing fluid — with PPE & 20 & 26 & 13 & 25 & 12 & No change & No change \\
\hline Produced water filtration & 0.47 & 0.55 & 0.45 & $\mathrm{NA}^{\mathrm{b}}$ & $\mathrm{NA}^{\mathrm{b}}$ & 0.46 & 0.50 \\
\hline Pipe cleaning-with PPE & 14 & 23 & 7.8 & 16 & 8.7 & 7.1 & 26 \\
\hline Storage tank cleaning-with PPE & 3.8 & 5.4 & 2.2 & $\mathrm{NA}$ & NA & 2.5 & 4.5 \\
\hline Sludge treatment workers - with PPE & 1.6 & 1.9 & 1.2 & 14 & 0.02 & 1.2 & 1.9 \\
\hline
\end{tabular}

a For conducting the sensitivity analyses, parameter values were reduced (low end) and increased (high end) by a factor of 2 from the base value for the parameter. For the worker involved in equipment cleaning at the gas processing facility, sensitivity analysis was not performed because the dose is very small.

b $\quad$ NA $=$ The scenario does not include any shielding. 
shield thickness using values of $0.5,1$, and $2 \mathrm{~cm}(0.2,0.4$, and $0.8 \mathrm{in}$.). Changing the source thickness by a factor of 2 was found to have no effect on the dose values.

For the workers involved in produced water filtration, most of the dose was from incidental ingestion. The sensitivity analyses were conducted on exposure distance using values of $0.15,0.3$, and $0.6 \mathrm{~m}(0.5,1$, and $2 \mathrm{ft})$ and on source thickness using values of $0.5,1$, and $2 \mathrm{~cm}$ $(0.2,0.4$, and 0.8 in.). No shielding was involved.

For the pipe cleaning worker scenario, the sensitivity analyses were conducted on exposure distance using values of $0.15,0.3$, and $0.6 \mathrm{~m}(0.5,1$, and $2 \mathrm{ft})$, on shield thickness using values of $0.5,1$, and $2 \mathrm{~cm}(0.2,0.4$, and $0.8 \mathrm{in}$.), and on source thickness using values of 0.325 , 0.65 , and $1.3 \mathrm{~cm}(0.1,0.2$, and $0.5 \mathrm{in}$.). For the storage tank cleaning scenario, sensitivity analyses were conducted on exposure distance using values of $0.15,0.3$, and $0.6 \mathrm{~m}(0.5,1$, and $2 \mathrm{ft})$ and on source thickness using values of $7.5,15$, and $30 \mathrm{~cm}(3,6$, and $12 \mathrm{in}$.). No shielding was involved.

For the sludge treatment worker, the sensitivity analyses were conducted on exposure distance using values of $0.5,1$, and $2 \mathrm{~m}(1.6,3.3$, and $6.6 \mathrm{ft})$, on shield thickness using values of 25,50 , and $100 \mathrm{~cm}(10,20$, and $39 \mathrm{in}$.), and on source thickness using values of 7.5, 15, and $30 \mathrm{~cm}(3,6$, and 12 in.).

An additional set of sensitivity runs was performed for each scenario in which the worker was assumed to be wearing PPE to test the risk if PPE were not worn. These results are shown in Table 6.5. If well site workers do not wear PPE, potential doses can be considerably higher in some scenarios. For the pipe cleaning worker, the dose could range from 390 to $650 \mathrm{mrem} / \mathrm{yr}$ for the average and maximum radionuclide concentrations, respectively. For the gas processing equipment cleaner, the doses could be as high as $670 \mathrm{mrem} / \mathrm{yr}$ assuming maximum concentrations. However, for the hydraulic fracturing fluid mixing and storage tank cleaner

TABLE 6.5 PPE Sensitivity Analysis Results for Well Site Operation Worker Scenarios

\begin{tabular}{lcccccc}
\hline & \multicolumn{2}{c}{ Maximum Concentration } & & \multicolumn{2}{c}{ Average Concentration } \\
\cline { 2 - 3 } \cline { 5 - 6 } & With PPE & Without PPE & & With PPE & Without PPE \\
\hline & & & & & \\
Mixing hydraulic fracturing fluid & 23 & 30 & & 20 & 26 \\
Pipe cleaning & 127 & 650 & & 14 & 390 \\
Storage tank cleaning & 70 & 73 & & 3.8 & 7.4 \\
Equipment cleaning at gas processing facility & 0.012 & 670 & & 0.0003 & 18 \\
Sludge treatment & 30 & 85.8 & & 1.6 & 15.4 \\
\hline
\end{tabular}

a The produced water filtration scenario was not included because it was assumed that these workers do not need to wear respirators, given the wet nature of the activity.

b PPE includes respirators, eye protection, and gloves. 
scenarios, the increase in dose is much smaller. This difference is due to the lower concentration of $\mathrm{Pb}-210$ in the wastes encountered during these activities, as $\mathrm{Pb}-210$ is a strong driver of the dose received through the ingestion pathway which increases without the proper use of PPE.

\subsection{RADIOLOGICAL DOSE FROM ACCIDENTAL PUBLIC EXPOSURE SCENARIOS}

The doses from accidental public exposures associated with improperly managed filter socks and proppants were estimated for three exposure scenarios: two filter sock exposure scenarios and one proppant exposure scenario. The assumptions and input parameters used to model the accidental public exposure scenarios are discussed in Section 3.2.1.1 and listed in Table B. 2 in Appendix B, respectively. For each scenario, one set of dose assessments used the average concentration and the other set used the maximum radionuclide concentrations. Doses were calculated for different times in the future ranging from 0 to 1,000 years.

Tables 6.6 and 6.7 list the time-dependent dose rates using the average and maximum filter socks concentrations for the two respective filter socks exposure scenarios. The doses to an individual child playing with used filter socks as a toy range from 0.036 to $0.052 \mathrm{mrem} / \mathrm{yr}$ (using average filter socks concentrations) and 0.21 to $0.42 \mathrm{mrem} / \mathrm{yr}$ (using maximum filter socks concentrations) at different times. Most of the dose is from the ingestion pathway because the child is assumed to come into direct contact with the filter socks. The doses to a city dweller exposed to filter socks in a city dumpster range from 0.39 to $0.51 \mathrm{mrem} / \mathrm{yr}$ (using average filter socks concentrations) to 2.7 to $4.9 \mathrm{mrem} / \mathrm{yr}$ (using maximum filter socks concentrations) at different times. The dose is from the external exposure pathway, only because the city dweller

\section{TABLE 6.6 Estimated Dose Rates for Maximum and Average Concentrations at Different Times for a Child Using Filter Socks as a Toy}

\begin{tabular}{|c|c|c|c|c|c|c|}
\hline \multirow{2}{*}{$\begin{array}{c}\text { Time } \\
(\mathrm{yr})\end{array}$} & \multicolumn{3}{|c|}{$\begin{array}{c}\text { Dose Rate }(\mathrm{mrem} / \mathrm{yr}) \text { at } \\
\text { Maximum Concentrations }\end{array}$} & \multicolumn{3}{|c|}{$\begin{array}{l}\text { Dose Rate }(\mathrm{mrem} / \mathrm{yr}) \text { at } \\
\text { Average Concentrations }\end{array}$} \\
\hline & External & Ingestion & Total & External & Ingestion & Total \\
\hline 0 & 0.022 & 0.19 & 0.21 & 0.0020 & 0.049 & 0.051 \\
\hline 3 & 0.024 & 0.21 & 0.23 & 0.0023 & 0.050 & 0.052 \\
\hline 10 & 0.022 & 0.25 & 0.27 & 0.0024 & 0.049 & 0.052 \\
\hline 30 & 0.019 & 0.32 & 0.34 & 0.0024 & 0.048 & 0.050 \\
\hline 100 & 0.019 & 0.40 & 0.42 & 0.0024 & 0.046 & 0.048 \\
\hline 120 & 0.018 & 0.40 & 0.42 & 0.0024 & 0.045 & 0.047 \\
\hline 150 & 0.018 & 0.40 & 0.42 & 0.0023 & 0.045 & 0.047 \\
\hline 300 & 0.017 & 0.38 & 0.40 & 0.0022 & 0.042 & 0.045 \\
\hline 500 & 0.016 & 0.35 & 0.37 & 0.0021 & 0.040 & 0.042 \\
\hline 1,000 & 0.013 & 0.29 & 0.30 & 0.0019 & 0.034 & 0.036 \\
\hline
\end{tabular}


TABLE 6.7 Estimated Dose Rates for Maximum and Average Concentrations at Different Times for a City Dweller Exposed to Filter Socks in a Dumpster

\begin{tabular}{|c|c|c|c|c|c|c|}
\hline \multirow{2}{*}{$\begin{array}{c}\text { Time } \\
(\mathrm{yr})\end{array}$} & \multicolumn{3}{|c|}{$\begin{array}{c}\text { Dose Rate }(\mathrm{mrem} / \mathrm{yr}) \text { at } \\
\text { Maximum Concentration }\end{array}$} & \multicolumn{3}{|c|}{$\begin{array}{l}\text { Dose Rate }(\mathrm{mrem} / \mathrm{yr}) \text { at } \\
\text { Average Concentration }\end{array}$} \\
\hline & External & Ingestion $^{\mathrm{a}}$ & Total & External & Ingestion $^{\mathrm{a}}$ & Total \\
\hline 0 & 4.4 & 0 & 4.4 & 0.40 & 0 & 0.40 \\
\hline 3 & 4.9 & 0 & 4.9 & 0.48 & 0 & 0.48 \\
\hline 10 & 4.5 & 0 & 4.5 & 0.51 & 0 & 0.51 \\
\hline 30 & 4.0 & 0 & 4.0 & 0.50 & 0 & 0.50 \\
\hline 100 & 3.8 & 0 & 3.8 & 0.49 & 0 & 0.49 \\
\hline 120 & 3.8 & 0 & 3.8 & 0.49 & 0 & 0.49 \\
\hline 150 & 3.7 & 0 & 3.7 & 0.48 & 0 & 0.48 \\
\hline 300 & 3.5 & 0 & 3.5 & 0.46 & 0 & 0.46 \\
\hline 500 & 3.3 & 0 & 3.3 & 0.44 & 0 & 0.44 \\
\hline 1,000 & 2.7 & 0 & 2.7 & 0.39 & 0 & 0.39 \\
\hline
\end{tabular}

a Because there is no direct contact with filter socks, there is no ingestionrelated dose.

does not come in direct contact with the filter socks. The potential dose to the city dweller is much higher compared with the potential total dose received by a child that uses filter socks as toy because of the difference in the assumed geometry of the source (i.e., the city dumpster is much bigger than the filter sock) and assumed exposure duration (i.e., the city dweller is exposed to the dumpster $40 \mathrm{~h} / \mathrm{yr}$, whereas the child is exposed to the toy $24 \mathrm{~h} / \mathrm{yr}$ ). For both scenarios, these doses are quite small compared with the 100-mrem/yr recommended dose limit to members of the general public (ICRP 1991).

For the proppant exposure scenario, it was assumed that a truckload of proppant material was illegally dumped in an open field. It was further assumed that children used that area as their playground and spent 2 hours every day there for 50 days (total exposure duration of 100 hours over the course of 1 year). Children were exposed by direct external exposure and ingestion pathways. Table 6.8 lists the time-dependent dose rates using the maximum and average proppant concentrations for the proppant exposure scenario. The doses to a child exposed to proppant at the playground range from 1.3 to $1.9 \mathrm{mrem} / \mathrm{yr}$ at different times (using maximum proppant concentrations) and from 1.2 to $1.7 \mathrm{mrem} / \mathrm{yr}$ (using average proppant concentrations). These doses are quite small compared with the 100-mrem per year dose limit to members of the general public (ICRP 1991). 
TABLE 6.8 Estimated Dose Rate for Maximum and Average Concentrations at Different Times for Proppant Used at a Playground

\begin{tabular}{|c|c|c|c|c|c|c|}
\hline \multirow{2}{*}{$\begin{array}{c}\text { Time } \\
(\mathrm{yr})\end{array}$} & \multicolumn{3}{|c|}{$\begin{array}{l}\text { Dose Rate }(\mathrm{mrem} / \mathrm{yr}) \text { at } \\
\text { Maximum Concentration }\end{array}$} & \multicolumn{3}{|c|}{$\begin{array}{l}\text { Dose Rate }(\mathrm{mrem} / \mathrm{yr}) \text { at } \\
\text { Average Concentration }\end{array}$} \\
\hline & External & Ingestion & Total & External & Ingestion & Total \\
\hline 0 & 1.3 & 0.071 & 1.3 & 1.1 & 0.063 & 1.2 \\
\hline 3 & 1.6 & 0.074 & 1.7 & 1.5 & 0.065 & 1.5 \\
\hline 10 & 1.8 & 0.074 & 1.9 & 1.6 & 0.066 & 1.7 \\
\hline 30 & 1.8 & 0.073 & 1.8 & 1.6 & 0.065 & 1.7 \\
\hline 100 & 1.7 & 0.071 & 1.8 & 1.6 & 0.064 & 1.6 \\
\hline 120 & 1.7 & 0.071 & 1.8 & 1.6 & 0.064 & 1.6 \\
\hline 150 & 1.7 & 0.071 & 1.8 & 1.6 & 0.063 & 1.6 \\
\hline 300 & 1.7 & 0.068 & 1.8 & 1.5 & 0.061 & 1.6 \\
\hline 500 & 1.6 & 0.065 & 1.7 & 1.5 & 0.059 & 1.5 \\
\hline 1,000 & 1.5 & 0.059 & 1.6 & 1.4 & 0.053 & 1.4 \\
\hline
\end{tabular}

\subsection{FUTURE-USE SCENARIOS}

\subsubsection{Calculated Radiological Dose to Source Ratio for Future-Use Scenarios}

An assessment was performed to estimate the potential radiological doses and related risks to hypothetical receptors for several future-use scenarios. In these analyses, it was assumed that once all landfill operations were completed, the landfill would be released to the public without restrictions. The radiological assessment was conducted for a landfill in which the TENORM is placed at $2 \mathrm{~m}(6 \mathrm{ft})$ below the top of the landfill. It was assumed that the landfill encompasses an area of $186,000 \mathrm{~m}^{2}\left(222,400 \mathrm{yd}^{2}\right)$, with the waste layer being $38 \mathrm{~m}(125 \mathrm{ft})$ thick (an adequate size for a Large Industrial Waste Landfill).

Five future-use scenarios were considered: (1) a residential-use scenario, in which a resident is assumed to construct a house on top of the landfill, use the surrounding area for growing crops, and obtain drinking and irrigation water from an on-site well; (2) an industrialuse scenario, in which the land encompassing the landfill is used for industrial purposes; (3) a recreational-use scenario, in which the landfill is turned into a recreational area; (4) an intruder scenario, in which an intruder digs through the waste and spreads the excavated soil outside and constructs a house on top of the contaminated area, uses the surrounding area for growing crops, and obtains the irrigation water from an on-site well; and (5) an off-site groundwater-use scenario, in which an off-site resident obtains water from a well drilled downgradient of the landfill. A detailed description of the future-use scenarios and receptors is provided in Section 3.2.2. 
As discussed in Section 4.2.3, this analysis was structured to first estimate the maximum allowable radionuclide concentration that could be disposed of without exceeding the dose limit of $100 \mathrm{mrem} / \mathrm{yr}$ (ICRP 1991) for future users, given multiple scenarios. It was assumed that $\mathrm{Ra}-226, \mathrm{Ra}-228$, Th-232, and $\mathrm{Pb}-210$ would be disposed of at the landfill. Therefore, the allowable concentrations of Ra-226, Ra-228, Th-232, and $\mathrm{Pb}-210$ were estimated. It was assumed that the short-lived progeny with half-lives less than 6 months are in secular equilibrium with the parent radionuclide (i.e., the radionuclide concentrations of the progeny are equal to the radionuclide concentration of the parent). Figure 6.1 shows the steps involved in estimating the allowable concentration at a specific landfill using future-use scenarios, which would result in the most conservative values.

Radionuclide concentrations in groundwater associated with the landfill operations were taken from the results of the hydrologic modeling conducted for this study (Section 5.3). The groundwater concentrations associated with a water table depth of $20 \mathrm{~m}(66 \mathrm{ft})$ were used; this depth corresponds to a conservatively shallow depth to water in the study area (Section 4.3.2). For the off-site groundwater-use scenario, the estimated groundwater concentrations at $100 \mathrm{~m}$ $(330 \mathrm{ft})$ downgradient of the landfill were used.

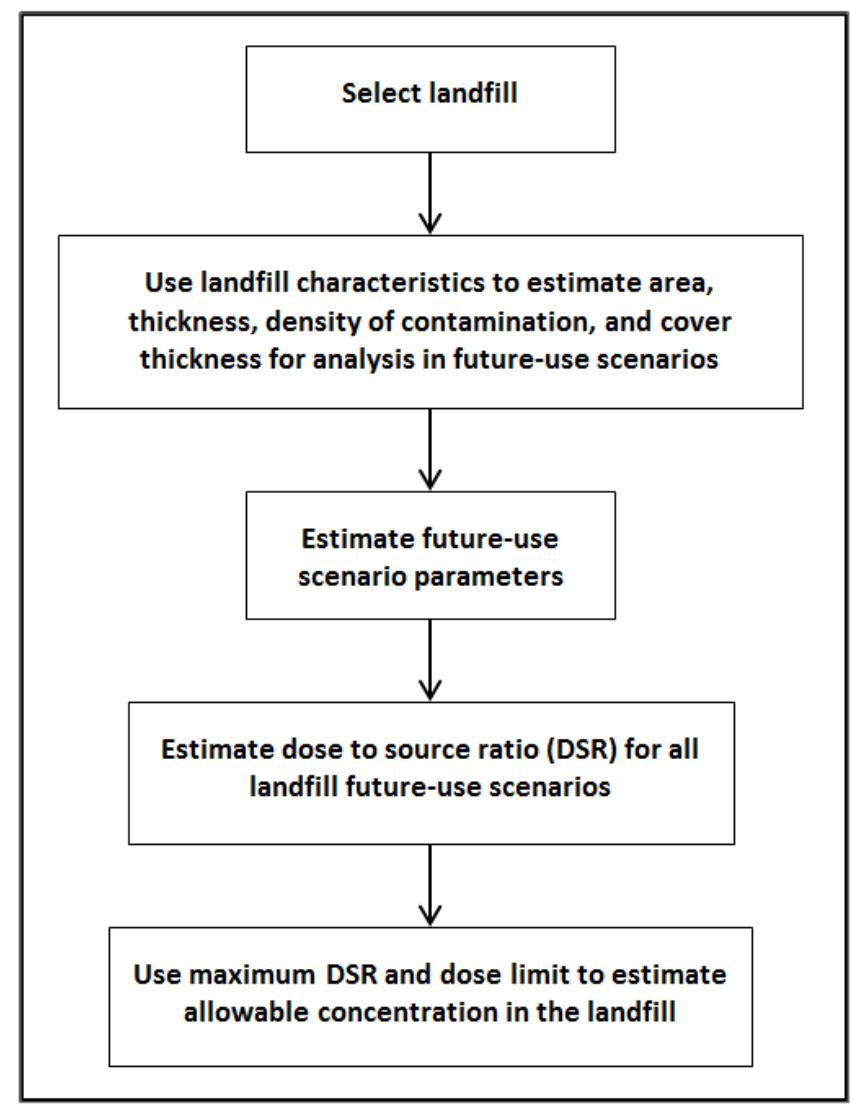

FIGURE 6.1 Steps Involved in Estimating the Allowable Concentration in the Landfill from Future-Use Scenarios 


\subsubsection{Results of Analysis for Different Radionuclides}

Dose to source ratios (DSRs) were estimated for individual radionuclides. Table 6.9 summarizes the maximum DSR for each scenario and identifies the limiting future-use scenario that results in maximum DSR among different scenarios for each radionuclide analyzed.

\subsubsection{Estimated Allowable Concentrations in the Landfill}

The limiting scenario DSR was used in estimating the average allowable concentration in the landfill based on a 100-mrem/yr public dose limit. It was assumed that TENORM is mixed with waste at the landfill and that TENORM waste is less than $10 \%$ of the total waste disposed of at the landfill. The allowable TENORM concentration can be 10 times higher compared with the average concentration at the landfill. Total activity that can be brought to the landfill was calculated by assuming that 25,000 tons of the TENORM waste is brought to the landfill every year. Table 6.10 lists the limiting average concentration in the landfill, allowable radionuclide concentration in the TENORM, and the total activity that can be brought to the landfill. In these calculations, it is assumed that only one radionuclide is present; if multiple radionuclides are disposed at a landfill, the sum of fractions should be used.

\subsubsection{Parameter Sensitivity Analyses for Future-Use Scenarios}

Depth to TENORM was found to be a very sensitive parameter. It represents the total depth to TENORM material in the landfill cell following landfill closure. The analysis is not sensitive to the specific type of cover. The total thickness may include only engineered cap material or may also include some thickness of clean fill material. The dose was estimated in five future-use scenarios considering a 1-m (3-ft) cover and 3-m (10-ft) depth to TENORM on the waste material disposed of at the landfill and the allowable landfill concentration that can result in the maximum dose of $100 \mathrm{mrem} / \mathrm{yr}$. Table 6.11 lists the limiting landfill concentration and the limiting scenario that establishes the minimum allowable concentrations at the landfill.

TABLE 6.9 Summary Results for Dose to Source Ratio

\begin{tabular}{|c|c|c|c|c|c|c|}
\hline \multirow[b]{2}{*}{ Radionuclide } & \multicolumn{5}{|c|}{ Maximum DSR (mrem/yr per pCi/g) for Each Scenario } & \multirow[b]{2}{*}{$\begin{array}{l}\text { Limiting } \\
\text { Scenario }\end{array}$} \\
\hline & Resident & Intruder & $\begin{array}{c}\text { Industrial } \\
\text { Worker }\end{array}$ & $\begin{array}{c}\text { Recreational } \\
\text { Visitor }\end{array}$ & $\begin{array}{c}\text { Off-site } \\
\text { Resident }^{\mathrm{a}}\end{array}$ & \\
\hline $\mathrm{Pb}-210$ & $9.0 \times 10^{-18}$ & $9.2 \times 10^{-2}$ & $2.6 \times 10^{-18}$ & $3.4 \times 10^{-20}$ & $1.80 \times 10^{-5}$ & Intruder \\
\hline Ra-226 & 7.7 & 4.4 & 2.6 & $2.6 \times 10^{-5}$ & $6.0 \times 10^{-3}$ & Resident \\
\hline Ra-228 & $4.8 \times 10^{-9}$ & 1.4 & $1.4 \times 10^{-9}$ & $1.8 \times 10^{-11}$ & $1.8 \times 10^{-18}$ & Intruder \\
\hline Th-232 & $2.0 \times 10^{-4}$ & 2.4 & $5.8 \times 10^{-5}$ & $7.4 \times 10^{-7}$ & $5.5 \times 10^{-2}$ & Intruder \\
\hline
\end{tabular}

a Doses were estimated using groundwater concentration. 
TABLE 6.10 Limiting Average Concentration Based on FutureUse Scenarios and Allowable TENORM Concentrations at the 100-mrem/yr Dose Limit Assuming a Two Meter-Thick Cover

\begin{tabular}{cccc}
\hline & $\begin{array}{c}\text { Limiting } \\
\text { Average } \\
\text { Concentration } \\
\text { in the Landfill } \\
(\mathrm{pCi} / \mathrm{g})\end{array}$ & $\begin{array}{c}\text { Allowable } \\
\text { Concentration in } \\
\text { the TENORM } \\
(\mathrm{pCi} / \mathrm{g})\end{array}$ & $\begin{array}{c}\text { Total Activity (Ci) } \\
\text { That Can Be Brought } \\
\text { to the Landfill in } \\
\text { Radionuclide }\end{array}$ \\
\hline Pb-210 & 1,100 & 11,000 & 270 \\
Ra-226 & 13 & 130 & 3.3 \\
Ra-228 & 70 & 700 & 18 \\
Th-232 & 41 & 410 & 10 \\
\hline
\end{tabular}

TABLE 6.11 Limiting Average Landfill Concentration (pCi/g) and Limiting Scenario with Maximum DSR by Radionuclide

\begin{tabular}{|c|c|c|c|c|c|c|}
\hline \multirow[b]{2}{*}{ Radionuclide } & \multicolumn{2}{|c|}{ 1-m Depth to TENORM } & \multicolumn{2}{|c|}{ 2-m Depth to TENORM } & \multicolumn{2}{|c|}{ 3-m Depth to TENORM } \\
\hline & $\begin{array}{c}\text { Allowable } \\
\text { Concentration } \\
(\mathrm{pCi} / \mathrm{g})\end{array}$ & $\begin{array}{l}\text { Limiting } \\
\text { Scenario }\end{array}$ & $\begin{array}{c}\text { Allowable } \\
\text { Concentration } \\
(\mathrm{pCi} / \mathrm{g})\end{array}$ & $\begin{array}{l}\text { Limiting } \\
\text { Scenario }\end{array}$ & $\begin{array}{c}\text { Allowable } \\
\text { Concentration } \\
(\mathrm{pCi} / \mathrm{g})\end{array}$ & $\begin{array}{l}\text { Limiting } \\
\text { Scenario }\end{array}$ \\
\hline $\mathrm{Pb}-210$ & 470 & Intruder & 1,100 & Intruder & $5.6 \times 10^{6}$ & $\begin{array}{c}\text { Groundwater, } \\
\text { Off-site }\end{array}$ \\
\hline Ra-226 & 8 & Resident & 13 & Resident & 36 & Resident \\
\hline Ra-228 & 30 & Intruder & 70 & Intruder & $5.0 \times 10^{14}$ & Resident \\
\hline Th-232 & 18 & Intruder & 41 & Intruder & 1,800 & $\begin{array}{c}\text { Groundwater, } \\
\text { Off-site }\end{array}$ \\
\hline
\end{tabular}

The groundwater concentration calculated by the hydrologic modeling was used to estimate the DSR for the off-site resident scenario; however, the groundwater concentration did not include the buildup of progeny. To evaluate the impact of progeny buildup on the analysis, the RESRAD-OFFSITE code (Yu et al. 2007) was used, because it includes buildup of progeny during the transport of contamination from the waste layer to the groundwater. In the analysis with the RESRAD-OFFSITE code, the most conservative parameters for groundwater transport were used, and the DSR for the off-site resident scenario was estimated. It was noted that the DSRs for Pb-210, Ra-226, and Th-232 for the off-site resident scenario were higher than those estimated using the groundwater concentration from the hydrologic modeling, but they did not change the limiting scenario for any case, and they did not result in more restrictive allowable concentrations, overall. 


\subsection{RADIOLOGICAL DOSE AND RISK FROM TRANSPORTATION}

A transportation risk assessment was performed for the transportation of TENORM wastes from the generation sites to a disposal site. In this analysis, only overland transportation using combined tractor-trailer trucks was evaluated. The transportation assessment consisted of evaluating the risks from both routine transport and transportation under accident conditions. Two major components of transportation risks were analyzed: cargo-related risks and vehiclerelated risks. The assumptions and input parameters used to model the transportation scenarios are discussed in Section 3.2.1.2 and listed in Tables B.7 and B.8 in Appendix B, respectively

Because the exact location of the disposal facility is unknown, the transportation risks to persons sharing and living along the transportation corridor were calculated on a per-kilometer basis. A base case value of $250 \mathrm{~km}$ (155 mi) was selected as a reasonable distance to the disposal facility. Transportation risks will be proportional to the distance to the disposal facility.

It was assumed that 25,000 tons of the TENORM waste is brought to the landfill in 1 year, and radionuclide concentrations in the TENORM are based upon the maximum allowed inventory at the landfill derived on the basis of the future-use scenarios. The allowable TENORM concentration values are presented in Table 6.9 and discussed in Section 6.3.3.

\subsubsection{Cargo-Related Doses and Risks}

Cargo-related risks were evaluated for both routine conditions and accident conditions. Under routine conditions, the cargo-related risks are associated with the external gamma radiation emanating from the TENORM shipment. The potential receptors include the driver, persons living along the transportation corridor, persons sharing the transportation corridor, and persons living near the entrance of a disposal site. Cargo-related risks are evaluated only for "one-way" distances, as the returning trucks would not contain any TENORM cargo.

Cargo-related risks under accidental conditions result from the dispersal of radioactive material following a transportation accident. These risks consider the probability of the accident occurring, the probability of the accident causing a release of radioactive material, and the consequence of the accident. The exposure pathways evaluated for cargo-related risks under accident conditions include external gamma radiation, inhalation of radioactive dust, and ingestion of contaminated material in food products. The radiological transportation risk is a function of the probability of the accident occurring, the release fraction of a given severity category, the probability of the accident severity category, and the dose associated with that accident severity category. Therefore, the transportation risk considers all types of accidents, ranging from minor collisions that do not release radioactive material, to major accidents that result in the release of the entire cargo of radioactive material. Although the units for cargorelated risks under accidents are the units of dose equivalent (mrem), it should be emphasized that the estimated dose is a product of the consequence of the accident, expressed in units of mrem, and the probability of the radioactive material being released to the environment, which is dimensionless. 
Radiological doses to an individual living near the disposal facility from routine transportation activities were estimated by assuming the individual would be present during each shipment; therefore, the total dose to this receptor is a product of the total number of shipments and the "per event" dose for a TENORM shipment passing near the disposal facility.

For the base case, an annual TENORM disposal rate of 25,000 tons per year was assumed. This number, which represents the expected annual waste disposal rate, translates into 1,000 shipments per year of TENORM wastes to the disposal facility. For the maximum case, assuming the maximum waste disposal rate of 50,000 tons per year (double the base case), the total number of shipments would be approximately 2,000 per year. The actual shipment could carry any radionuclide mix as long as the total dose at the landfill did not exceed the 100-mrem/yr dose limit. The allowable TENORM concentration values based on the future-use scenarios are presented in Table 6.9 and discussed in Section 6.3.3. The estimated dose rate at

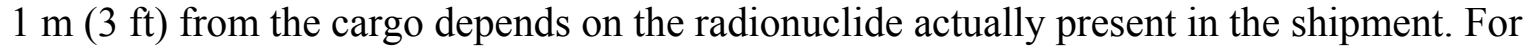
example, the external dose from a shipment that contains only Ra-226 would be higher compared with the dose from a shipment that contains only $\mathrm{Pb}-210$. Therefore, for the routine transportation assessment, the dose rate value of $0.025 \mathrm{mrem} / \mathrm{h}$ at $1 \mathrm{~m}(3 \mathrm{ft})$ was estimated from the radionuclide shipment that resulted in the maximum dose.

Table 6.12 provides the resultant doses and risks from the transportation of TENORM from the generation sites to the hypothetical landfill under both routine and accident conditions for the base case and maximum case number of shipments. The routine cargo-related doses to an individual living near the landfill range from $1.6 \times 10^{-6} \mathrm{mrem} / \mathrm{yr}$ (base case) to $3.2 \times 10^{-6} \mathrm{mrem} / \mathrm{yr}$ (maximum case). These doses are quite small compared with the $100-\mathrm{mrem} / \mathrm{yr}$ public dose limit and correspond to a risk of developing a radiation-induced latent fatal cancer of $9 \times 10^{-13}$ and $2 \times 10^{-12}$ for the base case and maximum case, respectively. Similarly, the collective doses to persons living along and sharing the transportation corridor range from $6.5 \times 10^{-5}$ person-rem/yr to $1.3 \times 10^{-4}$ person-rem/yr, based on a shipping distance of $250 \mathrm{~km}(155 \mathrm{mi})$. These doses correspond to developing $4 \times 10^{-8}$ to $7 \times 10^{-8}$ latent fatal cancers within the exposed collective population.

The annual dose to the driver was estimated to be approximately $20 \mathrm{mrem} / \mathrm{yr}$, with an annual cancer risk of $1 \times 10^{-5}$ for both the base case and maximum case. This dose estimate is based on the external dose rate at $2 \mathrm{~m}(0.01 \mathrm{mrem} / \mathrm{h})$ and assumes that no individual driver will exceed 2,000 hours. The radionuclide shipment that resulted in the maximum dose at allowable concentration at the landfill was used in estimating the dose to the driver. This dose estimate is conservative because the dose rate in the cab of the truck would be reduced due to shielding between the source and the driver, and it is unlikely that the same driver would be used for all TENORM shipments. Even with these conservative assumptions, the 20-mrem/yr dose to the driver is well below the $100-\mathrm{mrem} / \mathrm{yr}$ dose limit to the members of the general public (ICRP 1991).

The cargo-related transportation risks under accident conditions are also provided in Table 6.12. The transportation risks range from 3.6 person-rem/yr (base case) to 7.2 person$\mathrm{rem} / \mathrm{yr}$ (maximum case) for a shipping distance of $250 \mathrm{~km}(155 \mathrm{mi})$. These doses correspond to contracting $2 \times 10^{-3}$ to $4 \times 10^{-3}$ cancers each year in the exposed collective population. 


\section{TABLE 6.12 Cargo-Related Transportation Doses and Risks for Base Case and Maximum Case Conditions, Assuming a Transportation Distance of 250 km (155 mi)}

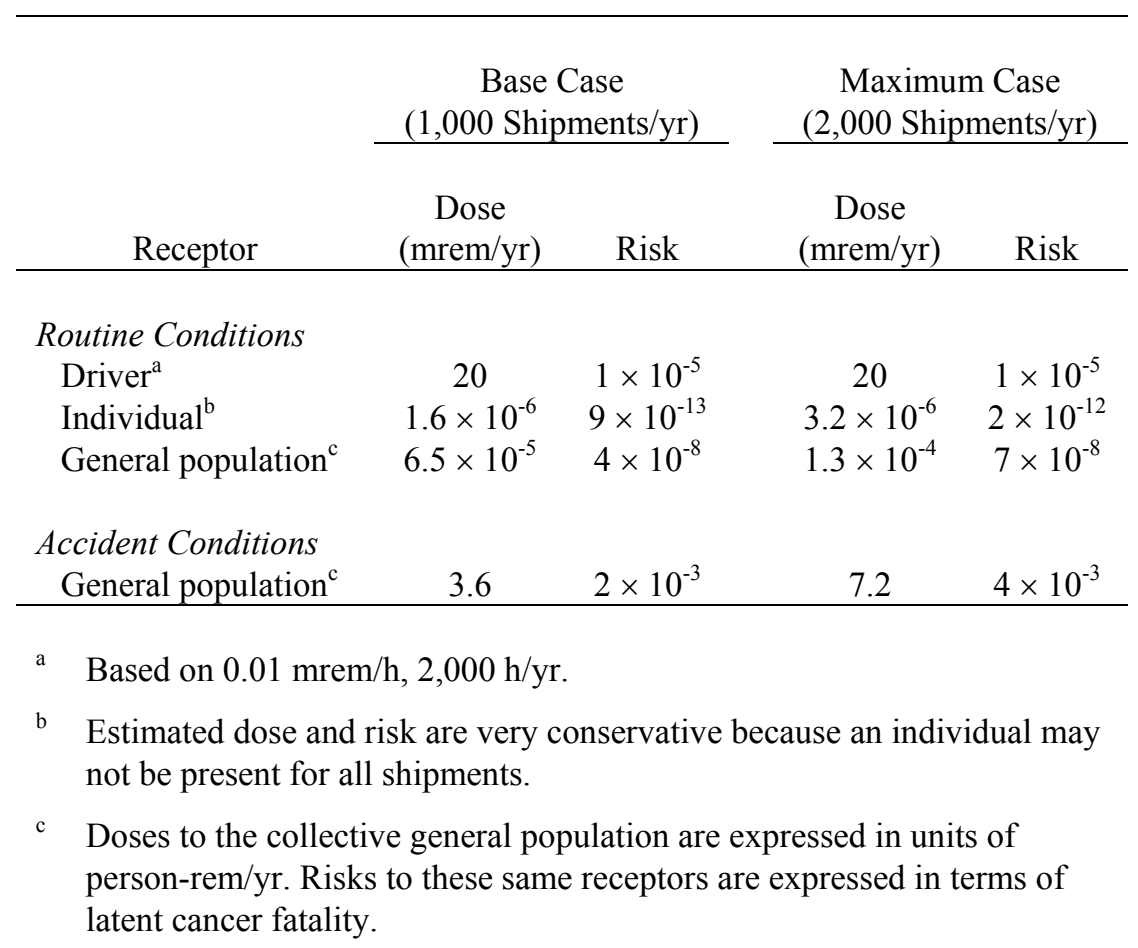

\subsubsection{Vehicle-Related Risks}

Vehicle-related risks are independent of the cargo being transported. These risks result in potential latent cancer fatalities (LCFs) from vehicular emissions and traffic fatalities due to transportation accidents. Vehicle-related risks are calculated based on round-trip distances, since these risks are independent of the cargo being transported. In other words, the same vehiclerelated risks are expected to occur when the transport vehicle is hauling a full load of TENORM waste from the generation site to the disposal facility as when the empty truck returns to the generation site from the disposal facility.

For risks associated with vehicular emissions, unit risk factors ( $\mathrm{LCF} / \mathrm{km}$ per person $\left./ \mathrm{km}^{2}\right)$ were obtained from Biwer and Butler (1999). Vehicle-related risks from vehicular emissions consider the size of the vehicle, diesel emissions from the vehicle, fugitive dust, and tire/brake particulates. For large tractor trailers (greater than 15 metric tons), the LCF unit risk factor was estimated at $8.36 \times 10^{-10}$ fatalities $/ \mathrm{km}$ per person $/ \mathrm{km}^{2}$ (Biwer and Butler 1999). A population density of 3.7 persons $/ \mathrm{km}^{2}$ was used in the transportation risk assessment (U.S. Census Bureau 2014).

Vehicle-related fatalities from truck transportation accidents have been estimated for transport in North Dakota (NDDOT 2012). It has been reported that the North Dakota average 
fatality rate associated with combination tractor-trailer trucks on interstate highways is $9.3 \times 10^{-9}$ fatalities per kilometer (NDDOT 2012).

Table 6.13 provides the results for the vehicle-related transportation risks based on a disposal facility located $250 \mathrm{~km}(155 \mathrm{mi})$ from the generation site. The risks themselves are based on a round-trip distance of $500 \mathrm{~km}(311 \mathrm{mi})$. For routine shipments, the risks range from $8 \times 10^{-7}$ fatalities $/ y r$ (base case) to $2 \times 10^{-6}$ fatalities per year (maximum case). Fatalities associated with vehicular accidents are larger than the estimated fatalities from latent fatal cancers and range from $5 \times 10^{-3}$ fatalities (base case) to $1 \times 10^{-2}$ fatalities per year (maximum case). The risk of getting involved in a fatal transportation accident is at least 100 times greater than that of the driver contracting a latent fatal cancer associated with the TENORM shipment.

\subsection{RADIOLOGICAL DOSE AND RISK FROM LANDFILL OPERATIONS}

Radiological doses and cancer risks were calculated for workers and the general public associated with the operational phase of the landfill. Two types of landfill operators were evaluated: waste handling and placement operators, and leachate management workers. Two sets of analyses were conducted for waste handling and placement operators. One set of analyses considered the bulk transport and disposal of TENORM wastes, while the other set of analyses considered shipment and disposal of the wastes in 200-L (55-gal) containers.

The operational phase receptors evaluated in this assessment included (1) workers involved in receiving and handling wastes, on-site transport, and disposal (i.e., waste placement in the landfill), (2) members of the general public, and (3) evaporation pond operators. The assumptions and input parameters used to model the landfill operational phase scenarios are discussed in Section 3.2.1.3 and listed in Tables B.3 through B.5 in Appendix B, respectively.

As discussed in Section 4.2.3, maximum allowable average TENORM concentrations in the landfilled wastes were back-calculated on the basis of the landfill future-use scenarios (see Section 6.3). These maximum allowable concentrations were then used to estimate potential doses to workers and the general public during the landfill operations. However, estimates of potential doses for the waste handling and placement operators using the maximum

TABLE 6.13 Vehicle-Related Transportation Risks for Base Case and Maximum Case Conditions, Assuming a Round-Trip Transportation Distance of 500 km (311 mi)

\begin{tabular}{lcc}
\hline & \multicolumn{2}{c}{ Fatalities per Year } \\
\cline { 2 - 3 } & Base Case & Maximum Case \\
Receptor & $(1,000$ Shipments/yr $)$ & $(2,000$ Shipments/yr $)$ \\
\hline & & \\
Routine conditions & $8 \times 10^{-7}$ & $2 \times 10^{-6}$ \\
Accident conditions & $5 \times 10^{-3}$ & $1 \times 10^{-2}$ \\
\hline
\end{tabular}


concentrations from the future-use scenario analyses exceeded the 100-mrem/yr general public dose limit. One way to reduce these doses to acceptable levels would be to reduce the volume of TENORM wastes disposed of at the landfill. Alternatively, the radionuclide concentrations in the TENORM wastes sent to the landfill also could be restricted to lower levels. In this assessment, additional calculations were run to derive lower maximum allowable TENORM concentrations for landfill disposal that would be protective of these workers.

\subsubsection{Waste Handling and Placement Operators}

The doses to these workers were first assessed on the basis of the maximum allowable TENORM concentrations calculated on the basis of the future-use scenarios presented in Table 6.10. The doses associated with the disposal of bulk or containerized TENORM wastes for the base case $(25,000$ ton/yr) to the waste handling and placement operators and members of the general public are summarized in Table 6.14. As shown in Table 6.14, the doses associated with the disposal of containerized TENORM are less than the doses associated with the disposal of TENORM in bulk because direct contact with the waste would be minimized. Doses to workers in many scenarios are above the 100-mrem/yr public dose limit (ICRP 1991). The workers associated with bulk waste receiving and handling or waste placement activities have the highest calculated doses overall.

TABLE 6.14 Radiological Dose Associated with Landfill Disposal of TENORM under the Base Case Scenario

\begin{tabular}{|c|c|c|c|c|c|c|c|c|}
\hline \multirow[b]{2}{*}{ Operations } & \multicolumn{4}{|c|}{ Bulk Waste Disposal } & \multicolumn{4}{|c|}{ Containerized Waste Disposal $^{\mathrm{a}}$} \\
\hline & $\mathrm{Pb}-210$ & Ra-226 & Ra-228 & Th-232 & $\mathrm{Pb}-210$ & Ra-226 & Ra-228 & Th-232 \\
\hline $\begin{array}{l}\text { Receiving and handling } \\
(\mathrm{mrem} / \mathrm{yr})\end{array}$ & $4.9 \times 10^{-1}$ & 130 & 390 & $1.1 \times 10^{-2}$ & $2.5 \times 10^{-1}$ & 75 & 210 & $1.1 \times 10^{-2}$ \\
\hline $\begin{array}{l}\text { On-site transport of } \\
\text { bulk/containerized waste } \\
\text { to landfill }(\mathrm{mrem} / \mathrm{yr})\end{array}$ & $2.1 \times 10^{-1}$ & 110 & 320 & $9.4 \times 10^{-3}$ & $2.1 \times 10^{-1}$ & 59 & 170 & $7.5 \times 10^{-3}$ \\
\hline $\begin{array}{l}\text { Waste placement } \\
(\mathrm{mrem} / \mathrm{yr})\end{array}$ & 260 & 120 & 350 & 850 & 1 & 120 & 350 & $3.9 \times 10^{-3}$ \\
\hline MEI (mrem/yr) & $2.1 \times 10^{-1}$ & $3.9 \times 10^{-3}$ & $3.3 \times 10^{-3}$ & $2.5 \times 10^{-1}$ & $2.1 \times 10^{-1}$ & $3.9 \times 10^{-3}$ & $3.3 \times 10^{-3}$ & $2.4 \times 10^{-1}$ \\
\hline $\begin{array}{l}\text { Collective population } \\
\text { dose (person-mrem) }\end{array}$ & $6.8 \times 10^{-1}$ & $1.2 \times 10^{-2}$ & $1.1 \times 10^{-2}$ & 830 & $6.8 \times 10^{-1}$ & $1.2 \times 10^{-2}$ & $1.1 \times 10^{-2}$ & 810 \\
\hline
\end{tabular}

a TENORM wastes are not expected to be released from the container during disposal operations, resulting in a smaller dose or risk to the general public.

b Doses to the collective general population are expressed in units of person-mrem/yr. 
Table 6.15 provides the total allowable activity of each radionuclide that could be disposed of at the landfill in order to limit the maximum dose to these workers to $100 \mathrm{mrem} / \mathrm{yr}$ or less. The resultant TENORM concentration based on worker scenarios is more restrictive compared with those derived for the future-use scenarios. The concentrations calculated for the worker involved in receiving and handling or waste placement activities are the limiting values.

\subsubsection{General Public Exposures Due to Landfill Operations}

Potential doses to the MEI of the general public are estimated to be low $(0.0033$ to $0.25 \mathrm{mrem} / \mathrm{yr}$ ) for the bulk disposal alternative. Collective population doses to persons living within $80 \mathrm{~km}(50 \mathrm{mi})$ of the disposal facility are estimated to range from 0.011 to 830 person$\mathrm{mrem} / \mathrm{yr}$ for the base case. These doses correspond to $6.3 \times 10^{-9}$ to $4.7 \times 10^{-4}$ per year LCFs, respectively, for the same collective population.

\subsubsection{Leachate Management Workers}

Table 6.16 summarizes the estimated worker doses associated with the operations of the evaporation pond based on the maximum allowable TENORM concentrations derived for the future-use scenarios. The radionuclide concentration at the evaporation pond is equal to the concentration in the leachate generated at the landfill.

The maximum estimated doses received by the leachate sampling worker range from 0.044 to $0.0096 \mathrm{mrem} / \mathrm{yr}$ from individual radionuclide activity in the evaporation pond. The maximum estimated doses received by the evaporation pond cleaning worker range from 0.0015 to $0.0070 \mathrm{mrem} / \mathrm{yr}$ from individual radionuclide activity in the evaporation pond. It was assumed that the evaporation pond is operational for 25 years. For Pb-210 and Ra-226, the maximum dose occurred at time zero, and for Ra-228 and Th-232, the maximum dose occurred at a later time due to the buildup of progeny.

TABLE 6.15 Allowable Total Radionuclide Activity (Ci) and the Resultant Allowable TENORM Concentration at the 100-mrem/yr Dose Limit

\begin{tabular}{|c|c|c|c|c|c|c|c|c|}
\hline \multirow[b]{2}{*}{ Operations } & \multicolumn{4}{|c|}{$\begin{array}{l}\text { Allowable Activity }(\mathrm{Ci}) \text { That Results in } \\
100-\mathrm{mrem} / \mathrm{yr} \text { Dose }\end{array}$} & \multicolumn{4}{|c|}{$\begin{array}{c}\text { Resultant Allowable TENORM } \\
\text { Concentration }(\mathrm{pCi} / \mathrm{g}) \\
\end{array}$} \\
\hline & $\mathrm{Pb}-210$ & Ra-226 & Ra-228 & Th-232 & $\mathrm{Pb}-210$ & Ra-226 & Ra-228 & Th-232 \\
\hline Receiving and handling & 56,000 & 2.4 & 4.5 & 90,000 & $2,200,000$ & 98 & 180 & $3,600,000$ \\
\hline $\begin{array}{l}\text { On-site transport of } \\
\text { dewatered/containerized } \\
\text { waste to landfill }\end{array}$ & 130,000 & 3.0 & 5.5 & 110,000 & $5,100,000$ & 120 & 220 & $4,400,000$ \\
\hline Waste placement & 110 & 2.6 & 5.0 & 1.2 & 4,200 & 110 & 200 & 48 \\
\hline
\end{tabular}


TABLE 6.16 Estimated Dose Rate (mrem/yr) from Evaporation Pond Operations

\begin{tabular}{|c|c|c|c|c|c|c|c|c|}
\hline \multirow{2}{*}{$\begin{array}{c}\text { Time } \\
(\mathrm{yr})\end{array}$} & \multicolumn{4}{|c|}{$\begin{array}{l}\text { Leachate Sampling Worker Dose } \\
(\mathrm{mrem} / \mathrm{yr})\end{array}$} & \multicolumn{4}{|c|}{$\begin{array}{l}\begin{array}{l}\text { Evaporation Pond Cleaning Worker Dose } \\
(\mathrm{mrem} / \mathrm{yr})\end{array} \\
\end{array}$} \\
\hline & $\mathrm{Pb}-210$ & Ra-226 & Ra-228 & Th-232 & $\mathrm{Pb}-210$ & Ra-226 & Ra-228 & Th-232 \\
\hline 0 & $1.8 \times 10^{-2}$ & $9.6 \times 10^{-3}$ & $3.3 \times 10^{-2}$ & $1.1 \times 10^{-2}$ & $2.9 \times 10^{-3}$ & $1.5 \times 10^{-3}$ & $5.3 \times 10^{-3}$ & $1.8 \times 10^{-}$ \\
\hline 1 & $1.8 \times 10^{-2}$ & $9.6 \times 10^{-3}$ & $4.1 \times 10^{-2}$ & $3.8 \times 10^{-3}$ & $2.8 \times 10^{-3}$ & $1.5 \times 10^{-3}$ & $6.5 \times 10^{-3}$ & $6.0 \times 10^{-1}$ \\
\hline 3 & $1.7 \times 10^{-2}$ & $9.6 \times 10^{-3}$ & $4.4 \times 10^{-2}$ & $9.9 \times 10^{-2}$ & $2.7 \times 10^{-3}$ & $1.5 \times 10^{-3}$ & $7.0 \times 10^{-3}$ & $1.6 \times 10^{-3}$ \\
\hline 5 & $1.6 \times 10^{-2}$ & $9.6 \times 10^{-3}$ & $4.1 \times 10^{-2}$ & $1.6 \times 10^{-2}$ & $2.5 \times 10^{-3}$ & $1.5 \times 10^{-3}$ & $6.5 \times 10^{-3}$ & $2.5 \times 10^{-3}$ \\
\hline 7 & $1.5 \times 10^{-2}$ & $9.6 \times 10^{-3}$ & $3.5 \times 10^{-2}$ & $2.1 \times 10^{-2}$ & $2.3 \times 10^{-3}$ & $1.5 \times 10^{-3}$ & $5.5 \times 10^{-3}$ & $3.4 \times 10^{-3}$ \\
\hline 9 & $1.4 \times 10^{-2}$ & $9.6 \times 10^{-3}$ & $2.9 \times 10^{-2}$ & $2.6 \times 10^{-2}$ & $2.2 \times 10^{-3}$ & $1.5 \times 10^{-3}$ & $4.6 \times 10^{-3}$ & $4.1 \times 10^{-3}$ \\
\hline 10 & $1.3 \times 10^{-2}$ & $9.6 \times 10^{-3}$ & $2.6 \times 10^{-2}$ & $2.8 \times 10^{-2}$ & $2.1 \times 10^{-3}$ & $1.5 \times 10^{-3}$ & $4.1 \times 10^{-3}$ & $4.4 \times 10^{-3}$ \\
\hline 15 & $1.1 \times 10^{-2}$ & $9.6 \times 10^{-3}$ & $1.5 \times 10^{-2}$ & $3.5 \times 10^{-2}$ & $1.8 \times 10^{-2}$ & $1.5 \times 10^{-3}$ & $2.4 \times 10^{-3}$ & $5.5 \times 10^{-3}$ \\
\hline 20 & $9.8 \times 10^{-3}$ & $9.5 \times 10^{-3}$ & $8.2 \times 10^{-2}$ & $3.9 \times 10^{-2}$ & $1.6 \times 10^{-2}$ & $1.5 \times 10^{-3}$ & $1.3 \times 10^{-3}$ & $6.1 \times 10^{-3}$ \\
\hline 25 & $8.4 \times 10^{-3}$ & $9.5 \times 10^{-3}$ & $4.5 \times 10^{-3}$ & $4.1 \times 10^{-2}$ & $1.3 \times 10^{-2}$ & $1.5 \times 10^{-3}$ & $7.2 \times 10^{-4}$ & $6.5 \times 10^{-3}$ \\
\hline
\end{tabular}

The radionuclide concentration at the evaporation pond could be much higher compared with the leachate concentration due to evaporation. Even if the evaporation pond concentrations were 100 times higher, the leachate sampling worker and evaporation pond cleaning worker doses would be much lower than $100 \mathrm{mrem} / \mathrm{yr}$.

\subsubsection{Parameter Sensitivity Analyses for Landfill Operation Scenarios}

As stated previously, the estimated doses for all the initial analyses were based on the maximum allowable concentration at the landfill derived from the future-use scenarios. However, because there is some uncertainty regarding the concentration of the TENORM radioisotopes, a sensitivity analysis on the TENORM concentration was conducted for the various disposal activities. The results for two worker scenarios for the maximum case are displayed on two-dimensional plots of dose (mrem) versus radionuclide concentration ( $\mathrm{pCi} / \mathrm{g}$ ) (Figures 6.2 and 6.3). Because any radionuclide mixture is possible, multiple isotopes are presented on the graphs; the total dose would be the sum of the estimated dose for each radionuclide present at any given concentration. As the plots indicate, dose is most sensitive to increasing concentrations of Th-232, and least sensitive to increasing concentrations of $\mathrm{Pb}-210$.

As stated earlier, the receiving and handling or waste placement worker for the bulk waste disposal alternative yielded the largest doses. A plot of potential dose to the receiving and handling worker versus TENORM concentration is provided in Figure 6.2. As shown in Figure 6.2, when concentrations of Ra-226 approach $100 \mathrm{pCi} / \mathrm{g}$, the dose to the worker is near $100 \mathrm{mrem} / \mathrm{yr}$. For the waste-placement worker, a similar plot of dose versus concentration is provided in Figure 6.3. In this case, the Ra-226 concentration can approach $105 \mathrm{pCi} / \mathrm{g}$ before the dose reaches $100 \mathrm{mrem} / \mathrm{yr}$. 


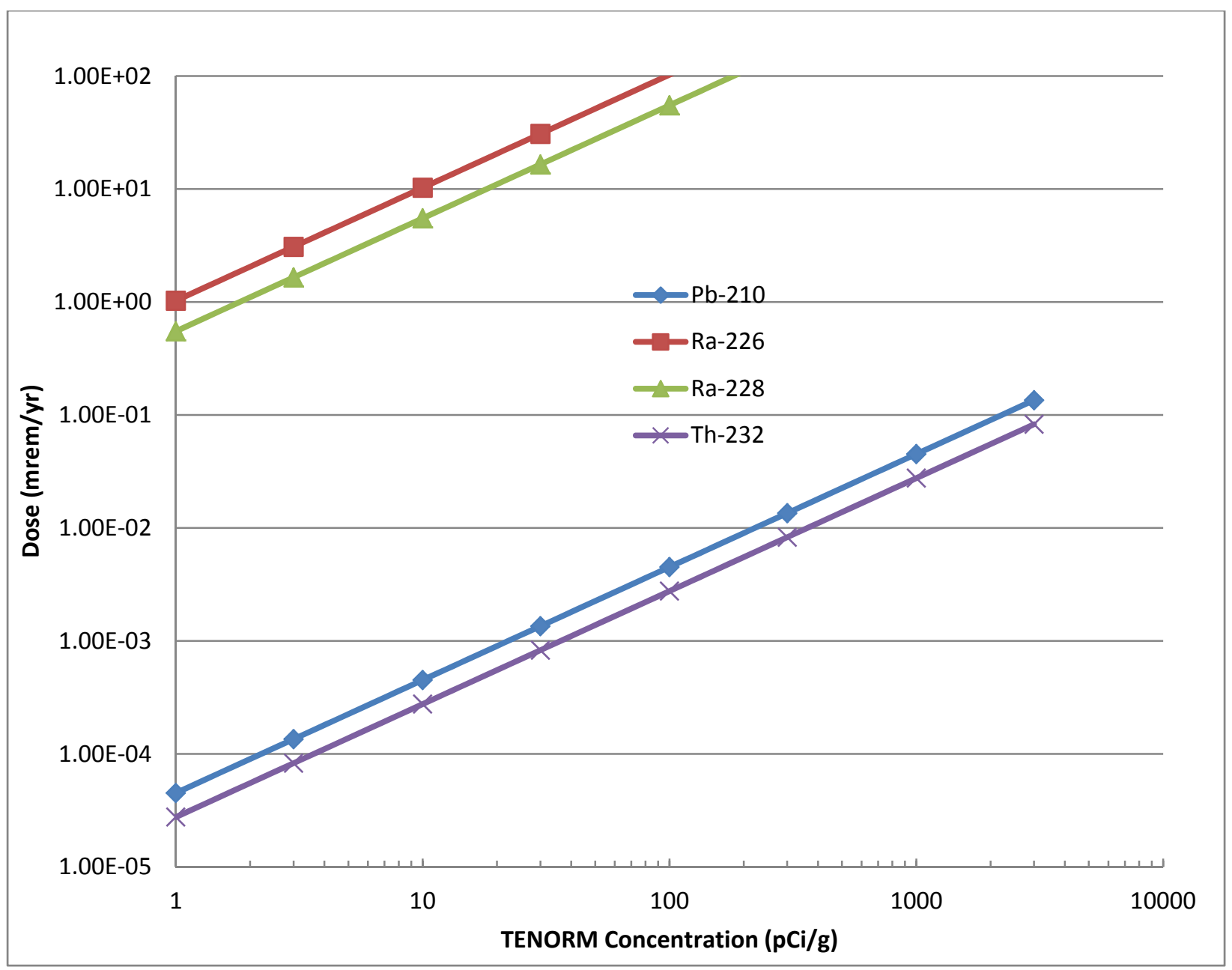

FIGURE 6.2 Worker Dose for Receiving and Handling TENORM Wastes at the Landfill

\subsection{SUMMARY OF DOSE AND RISK ASSESSMENT RESULTS}

As discussed in Section 6.1, potential doses to all of the well site workers are well below the 100-mrem/yr public dose limit assuming average radionuclides for TENORM wastes in North Dakota (see Table 6.2). Potential doses to the pipe cleaning worker (130 mrem/yr) and storage tank cleaning worker $(70 \mathrm{mrem} / \mathrm{yr})$ are of potential concern if the maximum radionuclide concentrations are assumed (see Table 6.3). Steps to reduce the exposures of these workers may be appropriate, including limiting their annual exposures. Most of the well site worker scenarios assumed the workers would be using PPE, including respirators. If PPE is not worn, potential doses to these workers would be unacceptably high (see Table 6.5).

As discussed in Section 6.2, based on the exposure scenarios modeled, potential doses to the general public related to accidental exposure to improperly managed filter socks and proppants are generally very low, even when maximum radionuclide concentrations are assumed. For the child exposed by playing with filter socks, the dose is below $0.5 \mathrm{mrem} / \mathrm{yr}$ for all calculations (Table 6.6). For the individual exposed to filter socks improperly disposed of in a 


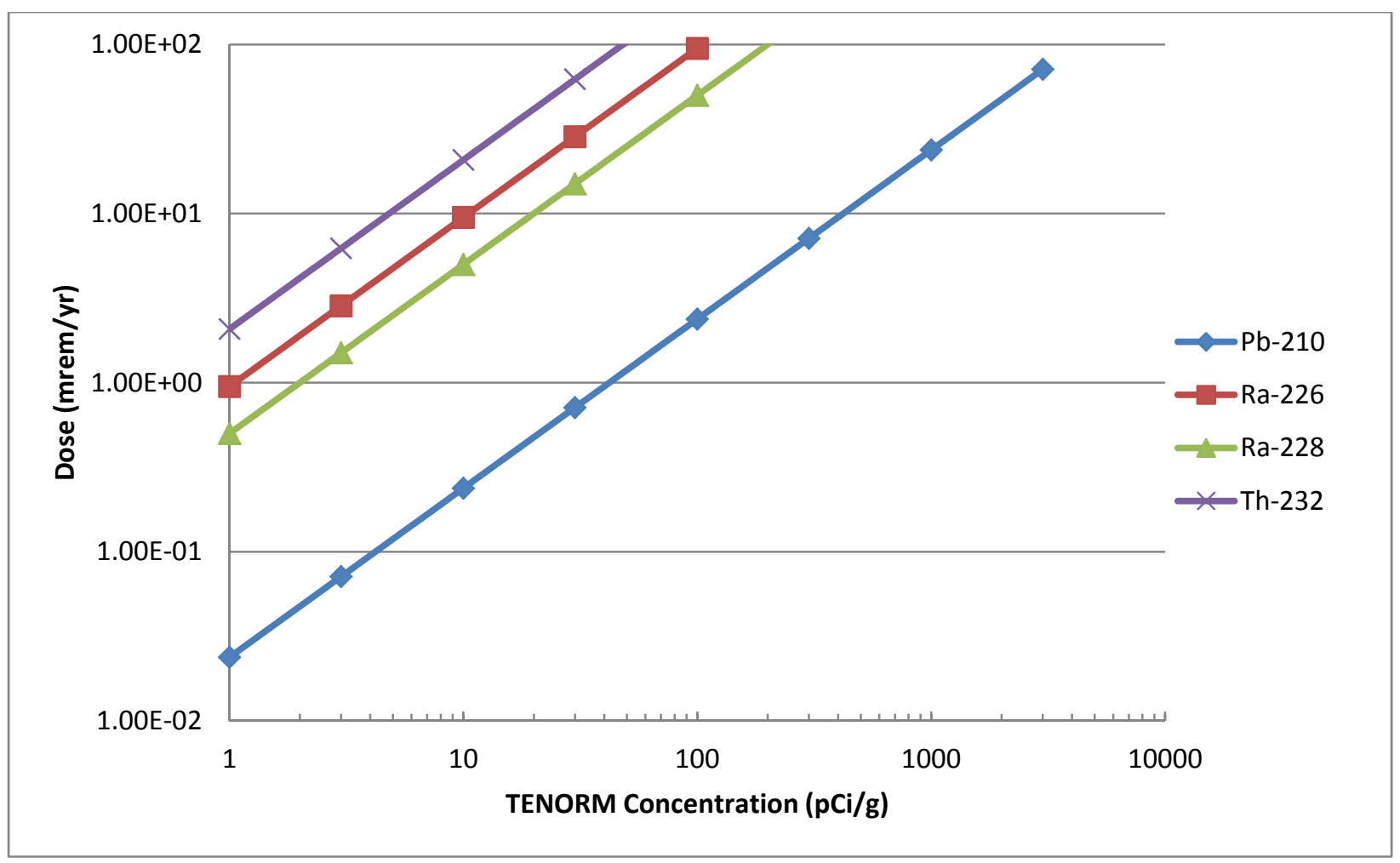

FIGURE 6.3 Worker Dose for Waste-Placement Activities at the Landfill

dumpster, the dose is below $1 \mathrm{mrem} / \mathrm{yr}$, assuming average concentrations, and below $5 \mathrm{mrem} / \mathrm{yr}$, assuming maximum concentrations (Table 6.7). Finally, for the child exposed by playing in spilled proppants, the doses are all below $2 \mathrm{mrem} / \mathrm{yr}$ for all calculations (Table 6.8). The scenarios evaluated in this study are not representative of all possible exposures related to improperly managed filter socks and proppants. Different exposure scenarios would result in different doses, some of which could be higher.

In Section 6.3, radionuclide-specific results were presented for the limiting average radionuclide concentration for wastes that could be disposed of in landfills, the maximum allowable concentration in the TENORM wastes, and the total activity level that could be safely disposed of in a single year, based on the evaluation of multiple future-use scenarios (Table 6.10). If multiple radionuclides are disposed of in a single landfill, the sum of fractions should be used to determine the appropriate limits. Sensitivity analyses indicate that Depth to TENORM waste is an important parameter. The limiting average radionuclide concentration for each individual radionuclide increases significantly as the Depth to TENORM increases from 1 to 2 to $3 \mathrm{~m}$ thick (Table 6.11).

As discussed in Section 6.5.1, landfill worker doses in many scenarios were above the 100-mrem/yr public dose limit using the allowable TENORM concentration (for a landfill with a 2-m [6-ft]-thick cover) based on future-use scenarios (see Table 6.14). The worker involved in receiving and handling or waste-placement activities received the highest dose. As a result, 
allowable TENORM concentrations based on the 100-mrem/yr limit for landfill workers were also derived (see Table 6.15). Table 6.17 compares the limiting TENORM concentrations based on the future-use scenarios (for a landfill with a 2-m [6-ft] depth of TENORM) and landfill worker scenarios.

The dose results presented for transportation (Section 6.4) and the leachate management worker scenarios (Section 6.5.3) are conservative because the results are based on the TENORM-allowed concentrations derived from the future-use scenarios. The actual doses received would be smaller, if the TENORM-allowed concentrations derived from the landfill operation phase worker scenarios were used.

\subsection{CALCULATING THE MAXIMUM ALLOWABLE RADIUM CONCENTRATION FOR TENORM DISPOSAL IN LANDFILLS IN NORTH DAKOTA}

Most state-level TENORM regulations establish limits specific to total radium concentration (i.e., Ra-226 plus Ra-228) in the waste stream. In the case of waste disposal criteria, such as the maximum allowable total radium concentration that can be disposed of in a landfill, these limits are independent of background levels of radium. For example, if the maximum allowable concentration is $50 \mathrm{pCi} / \mathrm{g}$ total radium, that is the total concentration allowable regardless of the background level at the landfill or point of generation.

Table 6.17 presents the results of estimated allowable TENORM concentrations for individual radionuclides. Data for TENORM wastes generated in North Dakota show that $\mathrm{Pb}-210$ and Th-232 also may be present in the waste streams along with radium isotopes. As shown in Table 6.17, Th-232 has the minimum estimated allowable TENORM concentration that can be disposed of at the landfill without exceeding the 100-mrem/yr dose limit for any worker or member of the public. Additional analyses are needed in order to calculate the maximum allowable total radium concentration that can be present in landfilled wastes, taking into account that Th-232 also may be present. This analysis entailed using the sum of fractions method for an assumed concentration of Th-232 per total radium concentration. As discussed in Section 2,

TABLE 6.17 Estimated Allowable TENORM Concentrations Based on Future-Use Scenarios and Landfill Worker Scenarios

\begin{tabular}{lcc}
\hline & \multicolumn{2}{c}{$\begin{array}{c}\text { Allowable TENORM Concentration } \\
(\mathrm{pCi} / \mathrm{g})\end{array}$} \\
\cline { 2 - 3 } & $\begin{array}{c}\text { Based on Landfill } \\
\text { Worker Scenarios }\end{array}$ & $\begin{array}{c}\text { Based on Future-Use } \\
\text { Scenarios }\end{array}$ \\
\hline Radionuclide & & \\
\hline Pb-210 & 4,200 & 11,000 \\
$\mathrm{Ra}-226$ & 98 & 130 \\
$\mathrm{Ra}-228$ & 180 & 700 \\
Th-232 & 48 & 410 \\
\hline
\end{tabular}


radionuclide concentration fractions were calculated using waste characterization data for North Dakota TENORM wastes (see Figure 2.1).

Mathematically, the sum of fractions is represented as shown in Equation 6.1.

$$
\sum_{i=1}^{n} \frac{\operatorname{Con}_{i}}{A C_{i}} \leq 1
$$

where

$\mathrm{Con}_{i}=$ concentration of radionuclide $i$ in the source,

$A C_{i}=$ allowable concentration of individual radionuclide $i$ at the dose limit, and

$n=$ total number of radionuclides above background present in the source.

When the activity fractions of radionuclides in the source are known, the total allowable concentration in the source at the dose limit can be estimated from the allowable concentration of individual radionuclide $i$ at the dose limit as presented in Equation 6.2.

$$
\frac{1}{A C S_{\text {total }}}=\sum_{i=1}^{n} \frac{W_{i}}{A C_{i}} \text {, }
$$

where

$W_{i}=$ the activity fraction of radionuclide $i$, and

$A C S_{\text {total }}=$ total allowable activity concentration in the source.

The total allowable concentration in the source was used to estimate the individual radionuclide allowable concentration in the source as presented in Equation 6.3.

$$
A C S_{i}=A C S_{\text {total }} \times W_{i}
$$

Table 6.18 presents the activity fractions of radionuclides and the resulting allowable concentration of individual radionuclides calculated using Equations 6.2 and 6.3. The calculation was performed utilizing average activity fractions and various assumed radionuclide concentration fractions to account for uncertainty. The maximum allowable total radium concentration that could be safely disposed of in a landfill without exceeding the $100-\mathrm{mrem} / \mathrm{yr}$ dose limit for any receptor, while also taking into account the additional activity from thorium that may be present, varied from $51.6 \mathrm{pCi} / \mathrm{g}$ to $66.6 \mathrm{pCi} / \mathrm{g}$. The lower concentration could be used to establish a limit of $50 \mathrm{pCi} / \mathrm{g}$ total radium for TENORM wastes disposed of in landfills. This value corresponds to the assumption that the ratios of Th-232 to total radium and of Ra-226 to total radium are both average, plus 1 SD (i.e., Th-232/total radium at 49\% and Ra-226/total radium at $80 \%$ ). While many individual waste samples may have activity fractions that would result in higher concentrations of Ra-226 and/or Th-232 compared with the $50 \mathrm{pCi} / \mathrm{g}$ total allowable radium concentration, the dose from cumulative exposure over time to a varying stream of waste would approach the average activity fractions over the 1-year time period modeled. 


\section{TABLE 6.18 Allowable Radionuclide Concentrations in the Waste Stream Disposed of at the}

Landfill Based on Different Radionuclide Concentration Fractions in the Waste Stream

\begin{tabular}{|c|c|c|c|c|c|c|c|c|}
\hline \multirow{3}{*}{$\begin{array}{l}\text { Radionuclide Concentration } \\
\text { Fractions in the Waste }\end{array}$} & & & & & \multicolumn{4}{|c|}{$\begin{array}{l}\text { Allowable Concentrations }(\mathrm{pCi} / \mathrm{g} \text { ) } \\
\text { in the Waste }\end{array}$} \\
\hline & \multicolumn{4}{|c|}{ Activity Fraction in the Waste } & \multirow[b]{2}{*}{$\mathrm{Ra}-226$} & \multirow[b]{2}{*}{$\mathrm{Ra}-228$} & \multirow[b]{2}{*}{ Th-232 } & \multirow{2}{*}{$\begin{array}{c}\text { Total } \\
\text { Radium } \\
\end{array}$} \\
\hline & Ra-226 & $\mathrm{Ra}-228$ & Th-232 & Total & & & & \\
\hline Average $^{a}$ & 0.49 & 0.27 & 0.24 & 87.2 & 43.0 & 23.6 & 20.6 & 66.6 \\
\hline $\begin{array}{l}\text { Average Th-232/total radium and } \\
\text { Ra-226/total radium at } 1 \mathrm{SD}^{\mathrm{b}}\end{array}$ & 0.61 & 0.15 & 0.24 & 83.3 & 50.8 & 12.8 & 19.7 & 63.6 \\
\hline $\begin{array}{l}\text { Average Ra-226/total radium }+ \\
1 \text { SD Th-232/total radium }{ }^{\mathrm{c}}\end{array}$ & 0.44 & 0.24 & 0.33 & 79.6 & 34.6 & 19.0 & 26.0 & 53.6 \\
\hline $\begin{array}{l}\text { Average }+1 \text { SD for both } \\
\text { Ra-226/total radium and } \\
\text { Th-232/total radium }{ }^{\mathrm{d}}\end{array}$ & 0.54 & 0.14 & 0.33 & 76.7 & 41.2 & 10.4 & 25.0 & 51.6 \\
\hline
\end{tabular}

a All radionuclides in the waste are present at average concentration (i.e., Th-232/total radium at 31\% and Ra-226/total radium at $65 \%$ ).

b Th-232/total radium is present at average concentration, and Ra-226/total radium is at average +1 SD (i.e., Th-232/total radium at $31 \%$ and $\mathrm{Ra}-226 /$ total radium at $80 \%$ ).

c Th-232/total radium is present at average concentration, and Ra-226/total radium is at average $+1 \mathrm{SD}$ (i.e., Th-232/total radium at $31 \%$ and $\mathrm{Ra}-226 /$ total radium at $80 \%$ ).

d Th-232/total radium and Ra-226/total radium both are at average $+1 \mathrm{SD}$ (i.e., Th-232/total radium at $49 \%$ and $\mathrm{Ra}-226 /$ total radium at $80 \%$ ). 
This page intentionally left blank. 


\section{CONCLUSIONS AND RECOMMENDATIONS}

This section presents conclusions drawn from the analyses presented in this report and recommendations for decisions and actions the NDDH may consider related to regulation of TENORM wastes.

\subsection{CONCLUSIONS}

The NDDH can use the results of this study to make decisions about the disposal of TENORM wastes in North Dakota Special Waste and Industrial Waste Landfills, even though waste characterization data are limited, and specific landfill locations have not been evaluated. Throughout the analyses, conservative assumptions have been made in the absence of definitive information. Although this approach could overestimate potential doses to receptors, it is a commonly used and prudent approach to ensure public health protection. Sensitivity analyses have been conducted on many parameters that might have a substantial bearing on the dose calculations in order to further support decisions about TENORM waste management at the well site, as well as TENORM landfill disposal.

The following general conclusions about well site operations, landfill disposal, and potential exposures to specific receptors are supported by the analyses and results presented in Sections 5 and 6.

- Potential doses to well site workers appear to be acceptable based upon average activity concentrations and the appropriate use of PPE. However, these doses can increase significantly and potentially even exceed recommended doses if concentrations approach the maximum of the range of activities shown in Table 2.1. The use of appropriate PPE is important to help minimize exposure, especially for workers performing cleaning tasks that may involve encountering scale.

- For well site operational scenarios, the pipe cleaning and storage tank cleaning workers received the highest doses. If maximum radionuclide concentrations are assumed, their doses are of potential concern (i.e., exceeding or approaching the ICRP's recommended public exposure limit of $100 \mathrm{mrem} / \mathrm{yr}$ ). These doses may be reduced to acceptable levels by limiting the workers' duration of exposure.

- The estimated doses from accidental public exposure to improperly managed filter socks and proppant were a small fraction of the public dose limit of $100 \mathrm{mrem} / \mathrm{yr}$ under all scenarios modeled. However, the scenarios evaluated in this study are not representative of all possible exposures related to improperly managed filter socks and proppants. 
- The estimated annual dose to the driver involved in transporting TENORM waste to the landfill was a small fraction of the public dose limit of $100 \mathrm{mrem} / \mathrm{yr}$. The transportation of the TENORM waste should not be a major component in deciding on the possible changes to the rules regarding TENORM disposal.

- Potential exposures to landfill workers are more restrictive than potential exposures related to future use of the landfill, in terms of the maximum TENORM concentrations that can be disposed of in the landfill safely. The workers involved in receiving and handling or waste placement activities received the highest dose.

- Increasing the depth of the TENORM wastes in the landfill can effectively reduce doses to future-use scenarios. Decreasing the volume of TENORM wastes that can be disposed of per year in a single landfill could effectively reduce doses to both landfill workers and future-use scenarios. Alternatively, potential doses could be reduced by limiting the number of hours that workers are exposed to the TENORM wastes.

- On the basis of the hydrologic modeling and the dose assessment results, disposal of TENORM wastes in both Industrial and Special Wastes Landfills is appropriate, provided certain restrictions are met. From a groundwater contamination perspective, TENORM wastes, therefore, may be appropriately disposed of in either landfill type. The thicker cover required for Industrial Waste Landfills (2 $\mathrm{m}$ [6 ft] as opposed to $1 \mathrm{~m}$ [3 ft]) results in lower potential doses to the receptors in all of the future-use scenarios modeled, except the off-site resident whose potential dose is independent of the landfill depth to TENORM.

- Further refinement of data parameters for the hydrologic modeling (e.g., sitespecific $\mathrm{K}_{d}$ values, site-specific hydrogeological data) is not warranted given that the groundwater exposure pathway is not a significant contributor to dose, except for scenarios assuming the thickest landfill cover (which limits other pathways) and very high concentrations of $\mathrm{Pb}-210$ and Th-232.

- Initial waste characterization data for TENORM waste streams generated by oil and gas production in North Dakota indicate that thorium may be present in the wastes in addition to radium. Establishing a total radium limit that takes into account the levels of thorium that may be present is a conservative approach that ensures potential exposures to workers and the general public are maintained below the recommended annual dose limit. 


\subsection{RECOMMENDATIONS}

The following recommendations are supported by the analyses and results presented in this report.

- For the maximum TENORM concentrations presented in Table 2.1, in order to keep exposures to acceptable levels, it may be necessary for workers to wear PPE (particularly respirators). This could be appropriate for all workers with inhalation exposure risks, including workers involved in pipe cleaning, storage tank cleaning, equipment cleaning at gas processing facilities, and sludge treatment.

- For the pipe cleaning and storage tank cleaning workers, additional analyses may be warranted to ensure that their exposures do not exceed or approach the ICRP's recommended public exposure limit of $100 \mathrm{mrem} / \mathrm{yr}$. It may be appropriate to limit the workers' duration of exposure.

- North Dakota solid waste regulations may be safely modified so that the maximum exposure to any landfill worker does not exceed $100 \mathrm{mrem} / \mathrm{yr}$, to allow TENORM wastes containing an average concentration of less than or equal to $50 \mathrm{pCi} / \mathrm{g}$ of total radium (independent of background radium levels) to be disposed of in either Special Waste or Industrial Waste Landfills, based on the following conditions:

- No more than 25,000 tons of TENORM wastes are disposed of in a single landfill per year.

- The average thorium activity concentration in the waste does not exceed $24 \mathrm{pCi} / \mathrm{g}$. (This concentration assumes a thorium to radium ratio of $49 \%$ at $50 \mathrm{pCi} / \mathrm{g}$ total radium, based on the conservative assumption that the ratios of Th-232 to total radium and of Ra-226 to total radium are both average, plus one SD greater than those in all samples observed for this report.)

- TENORM wastes must be covered by at least $2 \mathrm{~m}$ ( $6 \mathrm{ft}$ ) of a combination of the landfill cover materials and clean wastes that do not contain radionuclides. 
This page intentionally left blank. 


\section{REFERENCES}

Baird, R.D., G.B. Merrell, R.B. Klein, V.C. Rogers, and K.K. Nielson, 1990, Management and Disposal Alternatives for NORM Wastes in Oil Production and Gas Plant Equipment, RAE8837/2-1, prepared for American Petroleum Institute, Dallas, TX, by Rogers and Associates Engineering Corp., Salt Lake City, NV.

Barr Engineering, 2013, Site Characterization Investigation Report and Environmental Monitoring System Plan, WISCO Oilfield Special Waste Landfill, Williston, North Dakota, prepared for WISCO, Inc., Feb.

Bethke, C.M., and P.V. Brady, 2000, "How the $\mathrm{K}_{\mathrm{d}}$ Approach Undermines Ground Water Cleanup," Ground Water 38(3):435-443.

Biwer, B., and J.P. Butler, 1999, "Vehicle Emission Unit Risk Factors for Transportation Risk Assessments," Risk Analysis 19(6):1157-1171.

Brady, P.V., and C.M. Bethke, 2000, "Beyond the $\mathrm{K}_{\mathrm{d}}$ Approach," Ground Water 38(3):321-322.

Carlson McCain, Inc., 2012, Site Characterization Report, Chimney Butte Disposal Facility, Billings County, ND, prepared for Section 18, LLC, Mayer, MN, July 13.

DOE (U.S. Department of Energy), 1990, Radiation Protection of the Public and the Environment, DOE Order 5400.5, Feb.

Donovan, L., 2014a, "Potentially Radioactive Material Spilling Out of Trailers near Watford City," Bismarck Tribune, Feb 22.

Donovan, L., 2014b, "Radioactive Dump Site Found in Remote North Dakota Town," Bismarck Tribune, March 11.

Gelhar, L.W., C. Welty, and K.W. Rehfeldt, 1992, “A Critical Review of Data on Field-Scale Dispersion in Aquifers," Water Resources Research 28(7):1955-1974.

Golder (Golder Associates), 2013, Sawyer Landfill Cell D Design Report, Sawyer, North Dakota, prepared for Sawyer Disposal Services, LLC, May 23.

Harbaugh, A.W., E.R. Banta, M.C. Hill, and M.G. McDonald, 2000, MODFLOW-2000, The U.S. Geological Survey Modular Ground-water Model-User Guide to Modularization Concepts and the Ground-Water Flow Process, U.S. Geological Survey Open-File Report 00-92, Reston, VA. 
ICRP (International Commission on Radiological Protection), 1977, Recommendation of the International Commission on Radiological Protection, Publication 26, Pergamon Press, New York, NY.

ICRP, 1991, 1990 Recommendations of the International Commission on Radiological Protection, Publication 60, Pergamon Press, Oxford, United Kingdom.

ICRP, 2007, The 2007 Recommendations of the International Commission on Radiological Protection, ICRP Publication 103, Annals of the ICRP 37(2-4):1-332.

Michigan Department of Environmental Quality, 2007, Cleanup and Disposal Guidelines for Sites Contaminated with Radium-226, Waste and Hazardous Materials Division, Lansing, MI. Available at http://www.michigan.gov/documents/deq/whm-rps-EQC-1602-200703-cleanupdisposal-guidelines-radium-226_192499_7.pdf. Accessed Feb. 6, 2014.

MWH, 2012, Application for a Solid Waste Management Facility Permit, Tervita, LLC Proposed Special Waste Landfill, Tervita Blue Buttes Facility, McKenzie County, North Dakota, Nov.

NCRP (National Council on Radiation Protection and Measurements), 2009, Ionizing Radiation Exposure of the Population of the United States, Report No. 160.

NDAC (North Dakota Administrative Code), 2014, Article 33-20, "Solid Waste Management and Land Protection." Available at http://www.legis.nd.gov/information/acdata/html/33-20.html. Accessed Jan. 10, 2014.

NDDOT (North Dakota Department of Transportation), 2012, North Dakota Highway Safety Plan, 2013, prepared by the Safety Division, Traffic Safety Office, Sept. Available at http://www.dot.nd.gov/divisions/safety/docs/2013-HSP-Final.pdf.

NRC (U.S. Nuclear Regulatory Commission), 2014, “Doses in Our Daily Lives.” Available at http://www.nrc.gov/about-nrc/radiation/around-us/doses-daily-lives.html. Accessed Oct. 17, 2014.

Pfingston, M., et al., 1998, TSD-DOSE: A Radiological Dose Assessment Model for Treatment, Storage, and Disposal Facilities, ANL/EAD/LD-4 (Rev. 1), Argonne National Laboratory, Argonne, IL.

Poppke, T., 2014, personal communication by e-mail from Poppke (Division of Waste Management, North Dakota Department of Health) to C. Harto and others (Argonne National Laboratory), May 7.

Radig, S., 2013a, personal communication by e-mail from Radig (Division of Waste Management, North Dakota Department of Health) to K.P. Smith and others (Argonne National Laboratory), Dec. 9. 
Radig, S., 2013b, personal communication by e-mail from Radig (Division of Waste Management, North Dakota Department of Health) to K.P. Smith and others (Argonne National Laboratory), Dec. 19

Radig, S., 2013c, personal communication by e-mail from Radig (Division of Waste Management, North Dakota Department of Health) to K.P. Smith and others (Argonne National Laboratory), Dec. 17.

Radig, S., 2014a, personal communication by e-mail from Radig (Division of Waste Management, North Dakota Department of Health) to K.P. Smith and others (Argonne National Laboratory), Feb. 26.

Radig, S., 2014b, personal communication by e-mail from Radig (Division of Waste Management, North Dakota Department of Health) to K.P. Smith and others (Argonne National Laboratory), March 5.

Radig, S., 2014c, personal communication by e-mail from Radig (Division of Waste Management, North Dakota Department of Health) to C. Harto and others (Argonne National Laboratory), March 17.

Radig, S., 2014d, personal communication by e-mail from Radig (Division of Waste Management, North Dakota Department of Health) to C. Harto and others (Argonne National Laboratory), Jan. 14.

Schroeder, P.R., N.M. Aziz, C.M. Lloyd, and P.A. Zappi, 1994a, The Hydrologic Evaluation of Landfill Performance (HELP) Model: User's Guide for Version 3, EPA/600/R-94/168a, U.S. Environmental Protection Agency, Office of Research and Development, Washington, DC, Sept.

Schroeder, P.R., T.S. Dozier, P.A. Zappi, B.M. McEnroe, J.W. Sjostrom, and R.L. Peyton, 1994b, The Hydrologic Evaluation of Landfill Performance (HELP) Model: Engineering Documentation for Version 3, EPA/600/R-94/168b, U.S. Environmental Protection Agency, Office of Research and Development, Washington, DC, Sept.

Smith, K.P., D.L. Blunt, G.P. Williams, J.J. Arnish, M. Pfingston, J. Herbert, and R. Haffenden, 1999, An Assessment of the Disposal of Petroleum Industry NORM in Nonhazardous Landfills, DOE/BC/W-31-109-ENG-38-8 (OSTI ID: 13061), prepared for U.S. Department of Energy, National Petroleum Technology Office, Tulsa, OK.

Smith, K.P., H.I. Avci, J.J. Arnish, and J. Quinn, 2005, unpublished information, Argonne National Laboratory, Argonne, IL.

U.S. Census Bureau, 2014, 2010 Census Urban Lists Record Layouts. Available at http://www.census.gov/geo/reference/ua/ualists_layout.html. Accessed May 21, 2014. 
Waterloo Hydrologic, Inc., 2000, Visual HELP Version 2.2.0.2.

Weiner, R.F., et al., 2013, RADTRAN 6/RadCat 6 User Guide, SAND2013-8095, Sandia

National Laboratories, Albuquerque, NM, and Livermore, CA, Sept.

Wenck Associates, Inc., 2012a, Detailed Site Hydrogeologic Characterization \& Investigation Report, Ideal Oilfield Disposal, LLC, Special Waste Landfill, McKenzie County, North Dakota, prepared for Ideal Oilfield Disposal, Inc., Fargo, ND, Aug.

Wenck Associates, Inc., 2012b, Permit Application Design Report, Williston Landfill, prepared for Marquis Alliance Energy, Williston, ND, Nov.

Yu, C., et al., 2001, User's Manual for RESRAD, Version 6, ANL/EAD-4, Argonne National Laboratory, Argonne, IL.

Yu, C., et al., 2003, User's Manual for RESRAD-BUILD Version 3, ANL/EAD/03-1, Argonne National Laboratory, Argonne, IL.

Yu, C., et al., 2007, User's Manual for RESRAD-OFFSITE Version 2, ANL/EVS/TM-07-1, Argonne National Laboratory, Argonne, IL.

Zheng, C., and G.D. Bennett, 1995, Applied Contaminant Transport Modeling: Theory and Practice, Van Nostrand Reinhold, New York.

Zheng, C., and P.P. Wang, 1999, MT3DMS, A Modular Three-Dimensional Multi-Species Transport Model for Simulation of Advection, Dispersion, and Chemical Reactions of Contaminants in Groundwater Systems; Documentation and User's Guide, U.S. Army Engineer Research and Development Center Contract Report SERDP-99-1, Vicksburg, MS. 
APPENDIX A:

RADIONUCLIDE ANALYSIS DATA FOR TENORM WASTE SAMPLES COLLECTED IN NORTH DAKOTA 
This page intentionally left blank. 
TABLE A.1 Radionuclide Analysis Data for TENORM Waste Samples Collected in North Dakota

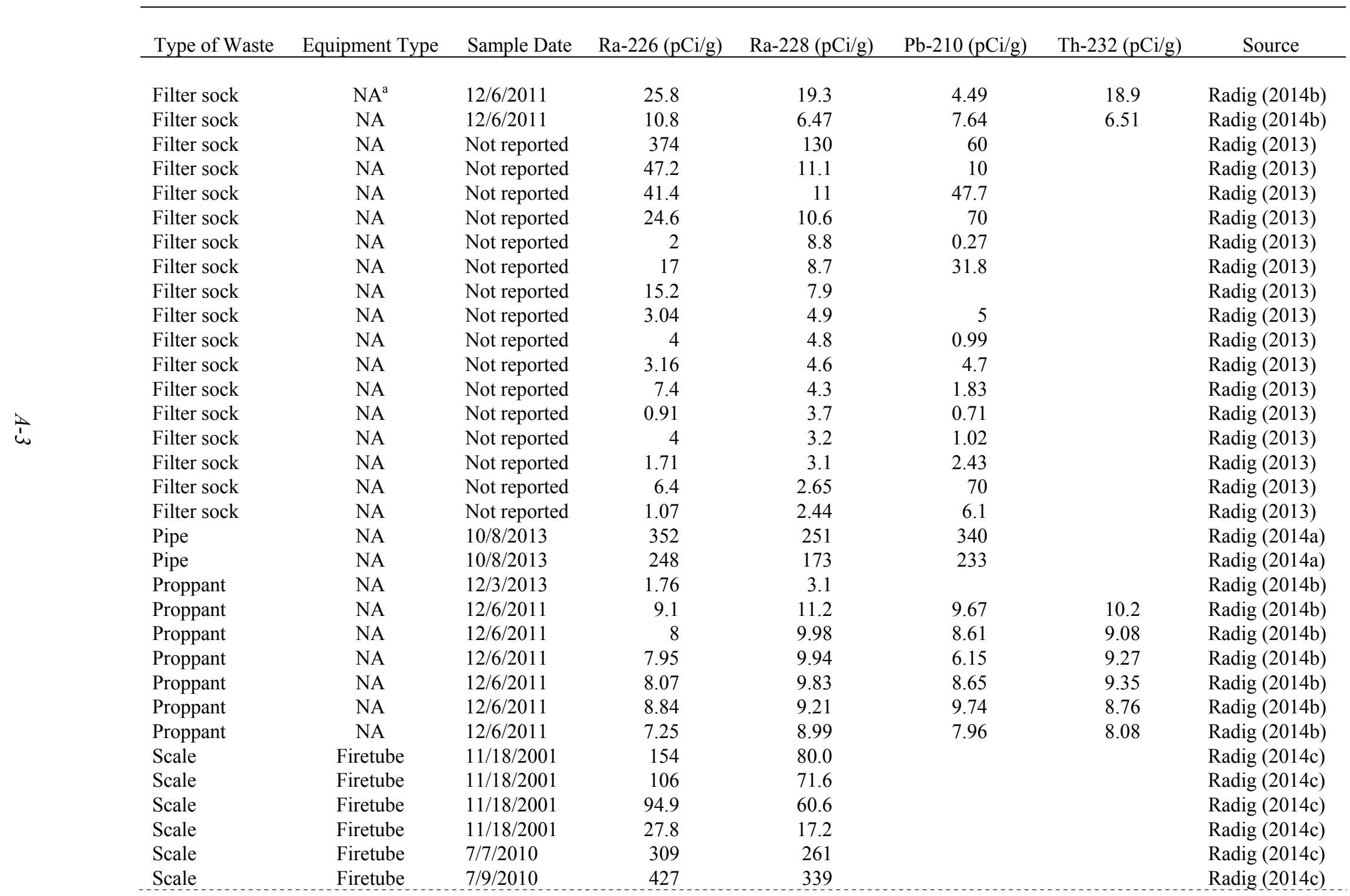


TABLE A.1 (Cont.)

\begin{tabular}{|c|c|c|c|c|c|c|c|}
\hline Type of Waste & Equipment Type & Sample Date & $\mathrm{Ra}-226$ (pCi/g) & $\mathrm{Ra}-228(\mathrm{pCi} / \mathrm{g})$ & $\mathrm{Pb}-210(\mathrm{pCi} / \mathrm{g})$ & Th-232 (pCi/g) & Source \\
\hline Scale & Firetube & $7 / 13 / 2010$ & 141 & 122 & & & Radig (2014c) \\
\hline Scale & Firetube & $7 / 13 / 2010$ & 4,700 & 3,590 & & & Radig (2014c) \\
\hline Scale & Firetube & $12 / 7 / 2010$ & 126 & 86.6 & & & $\operatorname{Radig}(2014 \mathrm{c})$ \\
\hline Scale & Firetube & $4 / 26 / 2011$ & $<77.7$ & $<8.1$ & & $<80.3$ & Radig (2014c) \\
\hline Scale & Firetube & $4 / 26 / 2011$ & $1,867.5$ & 971.4 & & 460.3 & Radig (2014c) \\
\hline Scale & Firetube & $4 / 26 / 2011$ & $1,386.1$ & 865.2 & & 247.2 & Radig (2014c) \\
\hline Scale & Firetube & $4 / 26 / 2011$ & 940.8 & 569.5 & & 109.9 & Radig (2014c) \\
\hline Scale & Firetube & $4 / 26 / 2011$ & 192.5 & 132.1 & & $<19.3$ & Radig (2014c) \\
\hline Scale & Firetube & $5 / 5 / 2011$ & 201.8 & 187.3 & & 83.2 & Radig (2014c) \\
\hline Scale & Firetube & $5 / 5 / 2011$ & 24.9 & 10.3 & & 30.3 & Radig (2014c) \\
\hline Scale & Firetube & $8 / 26 / 2011$ & 90.4 & 59.8 & & 28.6 & Radig (2014c) \\
\hline Scale & Firetube & $9 / 14 / 2011$ & $1,960.6$ & $<24.9$ & & 74.8 & Radig (2014c) \\
\hline Scale & Treater & $9 / 14 / 2011$ & 57.0 & $<2.6$ & & 13.4 & Radig (2014c) \\
\hline Scale & Firetube & 9/14/2011 & 56.6 & 38.4 & & 13.7 & $\operatorname{Radig}(2014 c)$ \\
\hline Scale & Firetube & 9/14/2011 & 25.7 & 18.4 & & 16.3 & $\operatorname{Radig}(2014 \mathrm{c})$ \\
\hline Scale & Firetube & $9 / 14 / 2011$ & 9.4 & 7.5 & & 7.7 & Radig (2014c) \\
\hline Scale & Filter sock & $10 / 5 / 2011$ & 42.9 & 24.5 & & & Radig (2014c) \\
\hline Scale & Tubing & $10 / 6 / 2011$ & $<115.2$ & $<23.6$ & & $<88.4$ & $\operatorname{Radig}(2014 c)$ \\
\hline Scale & Firetube & $10 / 18 / 2011$ & 180.0 & 131.6 & & 51.4 & $\operatorname{Radig}(2014 \mathrm{c})$ \\
\hline Scale & Firetube & $10 / 18 / 2011$ & 167.8 & 48.1 & & 36.5 & Radig (2014c) \\
\hline Scale & Filter sock & $10 / 18 / 2011$ & 63.5 & 39.5 & & $<23.6$ & Radig (2014c) \\
\hline Scale & Firetube & $10 / 18 / 2011$ & 31.5 & 19.0 & & 6.5 & Radig (2014c) \\
\hline Scale & Firetube & $10 / 18 / 2011$ & 14.0 & 9.0 & & 7.4 & $\operatorname{Radig}(2014 \mathrm{c})$ \\
\hline Scale & Firetube & $12 / 9 / 2011$ & 247.9 & 167.8 & & 93.3 & Radig (2014c) \\
\hline Scale & Firetube & $12 / 9 / 2011$ & 63.3 & 24.8 & & 23.8 & $\operatorname{Radig}(2014 c)$ \\
\hline Scale & Firetube & $1 / 20 / 2012$ & 271.5 & 155.6 & & 49.7 & $\operatorname{Radig}(2014 c)$ \\
\hline Scale & Firetube & $1 / 20 / 2012$ & 266.5 & 125.2 & & $<106.8$ & $\operatorname{Radig}(2014 \mathrm{c})$ \\
\hline Scale & Firetube & $1 / 20 / 2012$ & 160.3 & 107.4 & & 35.1 & Radig (2014c) \\
\hline Scale & Firetube & $1 / 20 / 2012$ & 123.8 & 60.8 & & 55.4 & Radig (2014c) \\
\hline Scale & Firetube & $2 / 17 / 2012$ & 392.6 & 271.5 & & 60.4 & $\operatorname{Radig}(2014 c)$ \\
\hline Scale & Firetube & $2 / 17 / 2012$ & 98.5 & 51.0 & & $<40.3$ & Radig (2014c) \\
\hline Scale & Pipe & $10 / 8 / 2013$ & 4,710 & 2,550 & 5,270 & & $\operatorname{Radig}(2014 a)$ \\
\hline Scoria & Soil & $2 / 17 / 2012$ & 2.6 & 2.2 & & $<2.9$ & Radig (2014c) \\
\hline
\end{tabular}


TABLE A.1 (Cont.)

\begin{tabular}{|c|c|c|c|c|c|c|c|}
\hline Type of Waste & Equipment Type & Sample Date & $\mathrm{Ra}-226(\mathrm{pCi} / \mathrm{g})$ & $\mathrm{Ra}-228(\mathrm{pCi} / \mathrm{g})$ & $\mathrm{Pb}-210(\mathrm{pCi} / \mathrm{g})$ & Th-232 (pCi/g) & Source \\
\hline Sludge & Treater & $10 / 14 / 2010$ & 64.5 & 2.7 & & & Radig (2014c) \\
\hline Sludge & Tank & $10 / 14 / 2010$ & 26.7 & 2.2 & & & Radig (2014c) \\
\hline Sludge & Tank & $10 / 25 / 2010$ & 5.5 & 2.5 & & & Radig (2014c) \\
\hline Sludge & Tank & $7 / 22 / 2011$ & 122.4 & 62.5 & & 34.4 & Radig (2014c) \\
\hline Sludge & Tank & $7 / 22 / 2011$ & $1,231.1$ & 62.2 & & & Radig (2014c) \\
\hline Sludge & Tank & $7 / 22 / 2011$ & 6.3 & 3.5 & & $<3.4$ & Radig (2014c) \\
\hline Sludge & Tank & $7 / 25 / 2011$ & 18.2 & 9.7 & & $<6.1$ & Radig (2014c) \\
\hline Sludge & Tank & $7 / 26 / 2011$ & 3.7 & 3.1 & & $<3$ & Radig (2014c) \\
\hline Sludge & Tank & $7 / 26 / 2011$ & 4.2 & 1.4 & & $<3.1$ & Radig (2014c) \\
\hline Sludge & Tank & $7 / 26 / 2011$ & 2.0 & 1.0 & & $<2.3$ & Radig (2014c) \\
\hline Sludge & Tank & $7 / 27 / 2011$ & 16.6 & 14.8 & & 8.6 & Radig (2014c) \\
\hline Sludge & Tank & $7 / 27 / 2011$ & 13.0 & 7.7 & & 5.1 & Radig (2014c) \\
\hline Sludge & Tank & $7 / 27 / 2011$ & 12.6 & 6.5 & & 6 & Radig (2014c) \\
\hline Sludge & Tank & $8 / 2 / 2011$ & 3.8 & $<0.5$ & & 2.1 & Radig (2014c) \\
\hline Sludge & Tank & $8 / 2 / 2011$ & 16.2 & 11.8 & & 6.5 & Radig (2014c) \\
\hline Sludge & Tank & $8 / 3 / 2011$ & 13.7 & 8.1 & & $<5.1$ & Radig (2014c) \\
\hline Sludge & Tank & $8 / 3 / 2011$ & 12.5 & 6.3 & & 4.4 & Radig (2014c) \\
\hline Sludge & Tank & $8 / 4 / 2011$ & 29.2 & 21.8 & & 7.4 & Radig (2014c) \\
\hline Sludge & Tank & $8 / 4 / 2011$ & 30.0 & 17.4 & & 9.4 & Radig (2014c) \\
\hline Sludge & Tank & $8 / 4 / 2011$ & 25.5 & 15.0 & & 13.2 & Radig (2014c) \\
\hline Sludge & Tank & $8 / 4 / 2011$ & 5.3 & 2.9 & & $<3.4$ & Radig (2014c) \\
\hline Sludge & Tank & $8 / 5 / 2011$ & 3.2 & 1.6 & & $<2.5$ & Radig (2014c) \\
\hline Sludge & Tank & $8 / 5 / 2011$ & 5.6 & 1.5 & & $<2.9$ & Radig (2014c) \\
\hline Sludge & Tank & $8 / 8 / 2011$ & 65.4 & 38.3 & & 21.5 & Radig (2014c) \\
\hline Sludge & Tank & $8 / 8 / 2011$ & 21.4 & 14.4 & & $<7$ & Radig (2014c) \\
\hline Sludge & Tank & $8 / 8 / 2011$ & 13.7 & 13.8 & & 6.5 & Radig (2014c) \\
\hline Sludge & Tank & $8 / 8 / 2011$ & 18.3 & 12.3 & & $<6.7$ & Radig (2014c) \\
\hline Sludge & Treater & $8 / 26 / 2011$ & 16.6 & 21.4 & & 16.3 & Radig (2014c) \\
\hline Sludge & Treater & $9 / 14 / 2011$ & 81.0 & $<4.2$ & & 18.3 & Radig (2014c) \\
\hline Sludge & Treater & $9 / 14 / 2011$ & 31.0 & 20.1 & & 14.6 & Radig (2014c) \\
\hline Sludge & Treater & $10 / 6 / 2011$ & 79.6 & 52.9 & & 22.4 & Radig (2014c) \\
\hline Sludge & Treater & $10 / 6 / 2011$ & 42.2 & 23.7 & & 15.9 & Radig (2014c) \\
\hline Sludge & Treater & $10 / 6 / 2011$ & 24.1 & 16.9 & & 9.1 & Radig (2014c) \\
\hline
\end{tabular}


TABLE A.1 (Cont.)

\begin{tabular}{|c|c|c|c|c|c|c|c|}
\hline Type of Waste & Equipment Type & Sample Date & $\mathrm{Ra}-226$ (pCi/g) & $\mathrm{Ra}-228(\mathrm{pCi} / \mathrm{g})$ & $\mathrm{Pb}-210(\mathrm{pCi} / \mathrm{g})$ & Th-232 (pCi/g) & Source \\
\hline Sludge & Treater & $12 / 9 / 2011$ & 59.2 & 36.9 & & 15.4 & Radig (2014c) \\
\hline Sludge & Treater & $12 / 9 / 2011$ & 24.5 & 11.8 & & $<6.2$ & Radig (2014c) \\
\hline Sludge & Treater & $1 / 20 / 2012$ & 58.7 & 39.7 & & 19.8 & Radig (2014c) \\
\hline Sludge & Tank & 9/9/2013 & 17.4 & $<1.6$ & & $<9.4$ & Radig (2014c) \\
\hline Sludge & Treater & $9 / 9 / 2013$ & 123.7 & 66.3 & & 97.5 & Radig (2014c) \\
\hline Sludge & Treater & $9 / 9 / 2013$ & 45.6 & 23.2 & & $<11.5$ & Radig (2014c) \\
\hline Sludge & Treater & $9 / 9 / 2013$ & 264.7 & 21.8 & & 33.9 & Radig (2014c) \\
\hline Sludge & Tank \& treater & 9/9/2013 & 36.8 & 21.0 & & 12.8 & Radig (2014c) \\
\hline Sludge & Tank & $9 / 9 / 2013$ & 33.6 & 18.2 & & 18.7 & Radig (2014c) \\
\hline Sludge & Tank \& treater & 9/9/2013 & 34.7 & 16.2 & & $<11.7$ & Radig (2014c) \\
\hline Sludge & Tank \& treater & $9 / 9 / 2013$ & 31.6 & 12.3 & & $<11.2$ & Radig (2014c) \\
\hline Sludge & Tank & $9 / 9 / 2013$ & 16.0 & 10.4 & & $<10.8$ & Radig (2014c) \\
\hline Sludge & Tank & $9 / 9 / 2013$ & 25.9 & 8.3 & & $<12$ & Radig (2014c) \\
\hline Sludge & Tank \& treater & 9/9/2013 & 24.6 & 8.3 & & $<10$ & Radig (2014c) \\
\hline Sludge & Tank \& treater & 9/9/2013 & 17.1 & 8.3 & & 9.3 & Radig (2014c) \\
\hline Sludge & Tank \& treater & $9 / 9 / 2013$ & 25.5 & 8.2 & & $<9.5$ & Radig (2014c) \\
\hline Sludge & Treater & 9/9/2013 & 19.7 & 7.7 & & $<7.1$ & Radig (2014c) \\
\hline Sludge & Flare pit & Not reported & 169 & 16.9 & 64 & & Radig (2013) \\
\hline Sludge & Flare pit & Not reported & 123 & 6.9 & 36.7 & & Radig (2013) \\
\hline Sludge & Tank & Not reported & 5.1 & 4.5 & 5.5 & & Radig (2013) \\
\hline Sludge & Flare pit & Not reported & 27.3 & 2.9 & 31.1 & & Radig (2013) \\
\hline Sludge & Flare pit & Not reported & 15.3 & 1.31 & 12.9 & & Radig (2013) \\
\hline Sludge & Flare pit & Not reported & 49.4 & 0.65 & 318 & & Radig (2013) \\
\hline Sludge & Flare pit & Not reported & 9 & 0.5 & 2.13 & & Radig (2013) \\
\hline
\end{tabular}

${ }^{\mathrm{a}} \mathrm{NA}=$ not applicable. 


\section{Appendix A References}

Radig, S., 2013, personal communication by e-mail from Radig (Division of Waste Management, North Dakota Department of Health) to K.P. Smith and others (Argonne National Laboratory), Dec. 9.

Radig, S., 2014a, personal communication by e-mail from Radig (Division of Waste Management, North Dakota Department of Health) to K.P. Smith and others (Argonne National Laboratory), Feb. 26.

Radig, S., 2014b, personal communication by e-mail from Radig (Division of Waste Management, North Dakota Department of Health) to K.P. Smith and others (Argonne National Laboratory), March 5.

Radig, S., 2014c, personal communication by e-mail from Radig (Division of Waste Management, North Dakota Department of Health) to C. Harto and others (Argonne National Laboratory), March 17. 
This page intentionally left blank. 


\section{APPENDIX B:}

RISK ASSESSMENT DATA TABLES 
This page intentionally left blank.

$B-2$ 


\section{APPENDIX B:}

RISK ASSESSMENT DATA TABLES

\section{TABLE B.1 RESRAD-BUILD Input Parameters Describing Well Site Operations}

\begin{tabular}{|c|c|c|}
\hline Parameter & Value & Remark $^{\mathrm{a}}$ \\
\hline \multicolumn{3}{|c|}{ Well Pad Workers } \\
\hline \multicolumn{3}{|c|}{ Mixing hydraulic fracturing fluid (exposed to proppant) } \\
\hline Exposure time $(\mathrm{h} / \mathrm{yr})$ & 2,000 & The inhalation and ingestion \\
\hline Exposure distance $(\mathrm{m})$ & 1 & pathways are excluded \\
\hline Source material & Concrete & because of the use of personal \\
\hline Source density $\left(\mathrm{g} / \mathrm{cm}^{3}\right)$ & 1.6 & protective equipment (PPE) \\
\hline Exposure source geometry & & (respirators, eye protection, \\
\hline Source length $(\mathrm{m})$ & 13.2 & and gloves). Direct external \\
\hline Source height (m) & 1.9 & exposure is the only applicable \\
\hline Source width (m) & 2.5 & pathway. Exposure is from the \\
\hline Shield material & Steel & blending operations in the \\
\hline Shield thickness $(\mathrm{cm})$ & 1 & sand blender. \\
\hline Shield density $\left(\mathrm{g} / \mathrm{cm}^{3}\right)$ & 7.86 & \\
\hline \multicolumn{3}{|c|}{ Produced water filtration (exposed to filter cake and filter socks) } \\
\hline Exposure time $(\mathrm{h} / \mathrm{yr})$ & 250 & The inhalation pathway is \\
\hline Exposure distance $(\mathrm{m})$ & 0.3 & excluded because of the wet \\
\hline Source material & Concrete & nature of the process. It is \\
\hline Source density $\left(\mathrm{g} / \mathrm{cm}^{3}\right)$ & 2.6 & assumed that this worker does \\
\hline Exposure source geometry & & not wear PPE somewhat \\
\hline Source diameter $(\mathrm{m})$ & 0.152 & infrequently on well sites. \\
\hline Source height (m) & 0.01 & May have service workers \\
\hline Shield thickness $(\mathrm{cm})$ & 0 & who do this most of the time. \\
\hline Shield density $\left(\mathrm{g} / \mathrm{cm}^{3}\right)$ & $\mathrm{NR}^{\mathrm{b}}$ & $\begin{array}{l}\text { May be similar to disposal } \\
\text { well worker exposures. }\end{array}$ \\
\hline \multicolumn{3}{|l|}{ Equipment Cleaners } \\
\hline \multicolumn{3}{|l|}{ Pipe cleaning (exposed to scale) ${ }^{\mathrm{c}}$} \\
\hline Exposure time $(\mathrm{h} / \mathrm{yr})$ & 2,000 & The inhalation and ingestion \\
\hline Distance $(\mathrm{m})$ & 0.3 & pathways are excluded \\
\hline Scale thickness $(\mathrm{cm})$ & 0.65 & because of the use of PPE. \\
\hline Scale density $\left(\mathrm{g} / \mathrm{cm}^{3}\right)$ & 2.6 & Direct external exposure is the \\
\hline Pipe length $(\mathrm{m})$ & 9.15 & only applicable pathway. \\
\hline Pipe diameter (m) & 0.15 & \\
\hline Shield material & Steel & \\
\hline Shield thickness $(\mathrm{cm})$ & 1 & \\
\hline Shield density $\left(\mathrm{g} / \mathrm{cm}^{3}\right)$ & 7.86 & \\
\hline
\end{tabular}


TABLE B.1 (Cont.)

\begin{tabular}{|c|c|c|}
\hline Parameter & Value & Remark \\
\hline \multicolumn{3}{|c|}{ Storage tank cleaning (exposed to scale and sludge) ${ }^{\mathrm{d}}$} \\
\hline Exposure time $(\mathrm{h} / \mathrm{yr})$ & 100 & The inhalation and ingestion \\
\hline Distance $(\mathrm{m})$ & 1 & pathways are excluded \\
\hline Scale material & Concrete & because of the use of PPE. \\
\hline Scale/sludge thickness $(\mathrm{cm})$ & 15 & Direct external exposure is the \\
\hline Scale/sludge density $\left(\mathrm{g} / \mathrm{cm}^{3}\right)$ & 1.6 & only applicable pathway. \\
\hline Tank length $(\mathrm{m})$ & 13.7 & \\
\hline Tank width (m) & 2.6 & \\
\hline Shield thickness (cm) & 0 & \\
\hline Shield density $\left(\mathrm{g} / \mathrm{cm}^{3}\right)$ & NR & \\
\hline \multicolumn{3}{|c|}{ Gas processing (exposed to $\mathrm{Pb}-210 \mathrm{film}^{\mathrm{e}}$} \\
\hline Exposure time $(\mathrm{h} / \mathrm{yr})$ & 2,000 & The inhalation and ingestion \\
\hline Exposure distance $(\mathrm{m})$ & 0.3 & pathways are excluded \\
\hline Source material & Concrete & because of the use of PPE. \\
\hline $\mathrm{Pb}-210$ film thickness $(\mathrm{cm})$ & 0.65 & Direct external exposure is the \\
\hline $\mathrm{Pb}-210$ film density $\left(\mathrm{g} / \mathrm{cm}^{3}\right)$ & 2.6 & only applicable pathway. \\
\hline Gas pipe length $(\mathrm{m})$ & 9.15 & Cleaning is done indoors. \\
\hline Gas pipe diameter $(\mathrm{m})$ & 0.15 & \\
\hline Shield material & Steel & \\
\hline Shield thickness (cm) & 1 & \\
\hline Shield density $\left(\mathrm{g} / \mathrm{cm}^{3}\right)$ & 7.86 & \\
\hline \multicolumn{3}{|c|}{ Disposal Well Worker } \\
\hline \multicolumn{3}{|c|}{ Filtration (exposed to filter cake and filter socks) } \\
\hline Exposure time $(\mathrm{h} / \mathrm{yr})$ & 2,000 & Exposure pathways and \\
\hline Exposure distance $(\mathrm{m})$ & 0.3 & parameter values are the same \\
\hline Source material & Concrete & as for well pad workers except \\
\hline Source density $\left(\mathrm{g} / \mathrm{cm}^{3}\right)$ & 2.6 & for the exposure time. \\
\hline \multicolumn{3}{|l|}{ Exposure source geometry } \\
\hline Source diameter $(\mathrm{m})$ & 0.152 & \\
\hline Source height $(\mathrm{m})$ & 0.01 & \\
\hline Shield thickness (cm) & 0 & \\
\hline Shield density $\left(\mathrm{g} / \mathrm{cm}^{3}\right)$ & NR & \\
\hline \multicolumn{3}{|c|}{ Sludge Treatment Plant Workers (exposed to sludge) } \\
\hline Exposure time $(\mathrm{h} / \mathrm{yr})$ & 2,000 & The parameters are assumed to \\
\hline Exposure distance $(\mathrm{m})$ & 1.0 & be similar as for storage tank \\
\hline Source material & Concrete & cleaning. However workers \\
\hline Sludge thickness $(\mathrm{cm})$ & 15 & would be shielded by water in \\
\hline Sludge density $\left(\mathrm{g} / \mathrm{cm}^{3}\right)$ & 1.6 & the tanks and the exposure \\
\hline Sludge tank length (m) & 13.7 & duration would be higher. No \\
\hline Sludge tank width (m) & 2.6 & exposure from the inhalation \\
\hline Shield material & Water & and ingestion pathways. \\
\hline Shield thickness (cm) & 50 & \\
\hline Shield density $\left(\mathrm{g} / \mathrm{cm}^{3}\right)$ & 1.0 & \\
\hline
\end{tabular}

\section{Footnotes on next page.}


TABLE B.1 (Cont.)

a If the inhalation and ingestion pathways are included, airborne dust loading of $1 \times 10^{-4} \mathrm{~g} / \mathrm{m}^{3}$, a worker inhalation rate of $1.2 \mathrm{~m}^{3} / \mathrm{h}$, and an ingestion rate of $6.25 \times 10^{-3} \mathrm{~g} / \mathrm{h}$ would be used from Smith et al.(1996).

b $\quad \mathrm{NR}=$ not required.

c Parameters for pipe cleaning activity are based on Smith et al. (1996).

d Sludge thickness, density, exposure duration, and distance are based on Smith et al. (1996).

e Pathways and parameters for equipment cleaning in gas processing activity are assumed to be the same as for pipe cleaning activity. It is assumed that the pipe is contaminated in gas processing. 


\section{TABLE B.2 Input Parameters Describing Public Exposures to the Unauthorized Release}

of Filter Socks and Proppants

\begin{tabular}{|c|c|c|}
\hline Parameter & Value & Remark \\
\hline \multicolumn{3}{|l|}{ Filter Sock Exposure Scenario 1} \\
\hline \multicolumn{2}{|l|}{ Filter socks used as a toy } & \multirow{9}{*}{$\begin{array}{l}\text { Ingestion and direct external } \\
\text { exposure pathways are included. }\end{array}$} \\
\hline Inadvertent ingestion rate $(\mathrm{g} / \mathrm{h})$ & $6.25 \times 10^{-3}$ & \\
\hline Exposure time $(\mathrm{h} / \mathrm{yr})$ & 24 & \\
\hline Distance $(\mathrm{m})$ & 0.5 & \\
\hline Source material & Concrete & \\
\hline Source material density $\left(\mathrm{g} / \mathrm{cm}^{3}\right)$ & 1 & \\
\hline \multicolumn{2}{|l|}{ Toy geometry ${ }^{\mathrm{a}}$} & \\
\hline Area $\left(\mathrm{cm}^{2}\right)$ & 90 & \\
\hline Length $(\mathrm{cm})$ & 10 & \\
\hline \multicolumn{3}{|l|}{ Filter Sock Exposure Scenario 2} \\
\hline \multicolumn{2}{|l|}{ Filter socks dumped in a dumpster ${ }^{\mathrm{b}}$} & \multirow{11}{*}{$\begin{array}{l}\text { Only direct external exposure } \\
\text { pathway is included because no } \\
\text { direct contact with the filter socks. }\end{array}$} \\
\hline Exposure time $(\mathrm{h} / \mathrm{yr})$ & 40 & \\
\hline Exposure distance $(\mathrm{m})$ & 1 & \\
\hline Shielding thickness (cm) & 0.32 & \\
\hline Shielding density $\left(\mathrm{g} / \mathrm{cm}^{3}\right)$ & 7.86 & \\
\hline Source material & Concrete & \\
\hline Source material density $\left(\mathrm{g} / \mathrm{cm}^{3}\right)$ & 1 & \\
\hline \multicolumn{2}{|l|}{ Dumpster geometry $(\mathrm{m})$} & \\
\hline Length & 1.83 & \\
\hline Width & 1.52 & \\
\hline Height & 1.1 & \\
\hline \multicolumn{3}{|l|}{ Proppant Exposure Scenario } \\
\hline \multicolumn{2}{|l|}{ Illegal dumping of proppant material on a field } & \multirow[t]{8}{*}{$\begin{array}{l}\text { Ingestion and direct external } \\
\text { exposure pathways are included. }\end{array}$} \\
\hline Exposure time $(\mathrm{h} / \mathrm{yr})$ & 100 & \\
\hline Exposure distance (m) & 1 & \\
\hline Source material & Concrete & \\
\hline Source material density $\left(\mathrm{g} / \mathrm{cm}^{3}\right)$ & 1.6 & \\
\hline \multicolumn{2}{|l|}{ Source geometry } & \\
\hline Area $\left(\mathrm{m}^{2}\right)$ & 10,000 & \\
\hline Thickness (m) & 0.15 & \\
\hline
\end{tabular}

a The toy is assumed to be in the shape of a cylindrical ball constructed with multiple filter socks such that the total weight of the toy does not exceed $1 \mathrm{~kg}$ (length $=10 \mathrm{~cm}$, area $=90 \mathrm{~cm}^{2}$, density $\left.=1 \mathrm{~g} / \mathrm{cm}^{3}\right)$.

b The dumpster is assumed to be constructed of 1/8-in. thick steel walls and has the dimensions of a 4-yd ${ }^{3}$ dumpster (6 ft length, $5 \mathrm{ft}$ width, and $3.6 \mathrm{ft}$ height). 
TABLE B.3 TSD-DOSE Input Parameters Describing Landfill Worker Operations for Disposing of Containerized Waste

\begin{tabular}{|c|c|c|}
\hline Parameter & Value & Remark \\
\hline \multicolumn{3}{|l|}{ Receiving and Handling } \\
\hline Density $\left(\mathrm{g} / \mathrm{cm}^{3}\right)$ & 1.4 & Used "Receiving and \\
\hline Inspect manifest: exposure time (h) & 1 & Sampling" operation in \\
\hline Inspect manifest: distance $(\mathrm{m})$ & 1 & TSD-DOSE code (Step A). \\
\hline \multicolumn{3}{|l|}{ On-site Transport of Containerized Waste } \\
\hline Density $\left(\mathrm{g} / \mathrm{cm}^{3}\right)$ & 1.4 & Used "Transport to TSD \\
\hline Load and secure shipment: exposure time (h) & 0.75 & Facility" operation in \\
\hline Distance to truck $(\mathrm{m})$ & 1 & TSD-DOSE code (Step A \\
\hline Drive time to landfill (h) & 0.25 & and Step B). \\
\hline Shielding thickness $(\mathrm{cm})$ & 0.16 & \\
\hline Distance to truck (m) & 2 & \\
\hline \multicolumn{3}{|l|}{ Truck bed/tank size (m) } \\
\hline Length & 6 & \\
\hline Width & 2 & \\
\hline Height & 1 & \\
\hline \multicolumn{3}{|l|}{ Containerized Waste Placement } \\
\hline Density $\left(\mathrm{g} / \mathrm{cm}^{3}\right)$ & 1.4 & Used “On-site Landfill” \\
\hline Unload containers: exposure time (h) & 0.75 & operation in TSD-DOSE \\
\hline Unload containers: distance $(\mathrm{m})$ & 1 & code (Step B and Step D). \\
\hline Mix waste: exposure time (h) & 0.75 & \\
\hline Mix waste: distance $(\mathrm{m})$ & 1 & \\
\hline Shielding thickness (cm) & 5 & \\
\hline \multicolumn{3}{|l|}{ Exposure geometry (m) } \\
\hline Length & 8 & \\
\hline Width & 2 & \\
\hline Height & 2 & \\
\hline
\end{tabular}

Source: Pfingston et al. (1998). 


\section{TABLE B.4 TSD-DOSE Input Parameters Describing Landfill Worker Operations}

for Disposing of Bulk Waste

\begin{tabular}{|c|c|c|}
\hline Parameter & Value & Remark \\
\hline $\begin{array}{l}\text { Receiving and Handling } \\
\text { Density }\left(\mathrm{g} / \mathrm{cm}^{3}\right) \\
\text { Inspect manifest: exposure time }(\mathrm{h}) \\
\text { Inspect manifest: distance }(\mathrm{m})\end{array}$ & $\begin{array}{c}0.7 \\
1 \\
1\end{array}$ & $\begin{array}{l}\text { Used "Receiving and } \\
\text { Sampling" operation in } \\
\text { TSD-DOSE code (Step A). }\end{array}$ \\
\hline $\begin{array}{l}\text { On-site Transport of Bulk Waste to Landfill Area } \\
\text { Density }\left(\mathrm{g} / \mathrm{cm}^{3}\right) \\
\text { Secure shipment: exposure time (h) } \\
\text { Distance to truck (m) } \\
\text { Drive time to landfill (h) } \\
\text { Shielding thickness (cm) } \\
\text { Distance to truck (m) } \\
\text { Truck bed/tank size (m) } \\
\text { Length } \\
\text { Width } \\
\text { Height }\end{array}$ & $\begin{array}{c}0.7 \\
0.75 \\
1 \\
0.25 \\
0.16 \\
2\end{array}$ & $\begin{array}{l}\text { Used "Transport to TSD } \\
\text { Facility" operation in TSD- } \\
\text { DOSE code (Step A and } \\
\text { Step B). }\end{array}$ \\
\hline $\begin{array}{l}\text { Disposal at the Landfill and Waste Placement } \\
\text { Density }\left(\mathrm{g} / \mathrm{cm}^{3}\right) \\
\text { Unload waste: exposure time }(\mathrm{h}) \\
\text { Unload waste: distance }(\mathrm{m}) \\
\text { Airborne respirable dust concentration }\left(\mathrm{g} / \mathrm{m}^{3}\right) \\
\text { Mix waste at the landfill: exposure time }(\mathrm{h}) \\
\text { Mix waste at the landfill: exposure distance }(\mathrm{m}) \\
\text { Shielding thickness }(\mathrm{cm}) \\
\text { Exposure geometry }(\mathrm{m}) \\
\text { Length } \\
\text { Width } \\
\text { Height }\end{array}$ & $\begin{array}{l}1.4 \\
0.75 \\
1 \\
1.0 \times 10^{-3} \\
0.75 \\
1 \\
5 \\
\\
8 \\
2 \\
2\end{array}$ & $\begin{array}{l}\text { Used "On-site Landfill" } \\
\text { operation in TSD-DOSE } \\
\text { code (Step A and Step B). } \\
\text { Used "On-site Landfill" } \\
\text { operation in TSD-DOSE } \\
\text { code (Step A and Step B). }\end{array}$ \\
\hline $\begin{array}{l}\text { Maximally Exposed Individual (MEI)/Collective } \\
\text { Population Bulk Disposal } \\
\text { Exposure time }(\mathrm{h}) \\
\text { Exposure frequency }(\mathrm{d} / \mathrm{yr}) \\
\text { MEI distance to source }(\mathrm{km}) \\
\text { Wind speed }(\mathrm{m} / \mathrm{s}) \\
\text { Percentage of time wind blows in direction }(\%)\end{array}$ & $\begin{array}{c}24 \\
365 \\
0.3 \\
4 \\
50\end{array}$ & $\begin{array}{l}\text { Bulk disposal results in } \\
\text { general public exposure. }\end{array}$ \\
\hline Population density: 0-20 mi (persons $/ \mathrm{mi}^{2}$ ) & 9.7 & $\begin{array}{l}\text { Average from } 2010 \text { Census } \\
\text { data for North Dakota. } \\
\text { Average from } 2010 \text { Census } \\
\text { data for North Dakota. }\end{array}$ \\
\hline
\end{tabular}

Sources: Pfingston et al. (1998); U.S. Census Bureau (2014). 
TABLE B.5 RESRAD-BUILD Input Parameters Describing Evaporation Pond Worker Operations

\begin{tabular}{|c|c|c|}
\hline Parameter & Value & Remark/Assumption \\
\hline Evaporation Pond Worker Activities & & $\begin{array}{l}\text { Water concentration calculated from the leachate } \\
\text { concentration. }\end{array}$ \\
\hline \multicolumn{3}{|l|}{ Leachate Sampling } \\
\hline Exposure time $(\mathrm{h})$ & 60 & Sample is collected every day and sampling time is \\
\hline Distance to pond (m) & 0.5 & 10 minutes. \\
\hline Source material & Water & \\
\hline Source material density $\left(\mathrm{g} / \mathrm{cm}^{3}\right)$ & 1 & \\
\hline \multicolumn{3}{|l|}{ Exposure geometry $(\mathrm{m})$} \\
\hline Length & 100 & Pond size is $100 \mathrm{~m}$ by $100 \mathrm{~m}$ and water depth is $2 \mathrm{~m}$. \\
\hline Width & 100 & \\
\hline Height & 2 & \\
\hline \multicolumn{3}{|l|}{ Evaporation Pond Cleaning } \\
\hline Exposure time (h) & 10 & Cleaning is performed 60 times $/ \mathrm{yr}$, and it takes \\
\hline Distance to pond (m) & 1 & 10 minutes to remove debris collected at the pond. \\
\hline Source material & Water & \\
\hline Source material density $\left(\mathrm{g} / \mathrm{cm}^{3}\right)$ & 1 & \\
\hline \multicolumn{3}{|l|}{ Exposure geometry $(\mathrm{m})$} \\
\hline Length & 100 & Pond size is $100 \mathrm{~m}$ by $100 \mathrm{~m}$ and water depth is $2 \mathrm{~m}$. \\
\hline Width & 100 & \\
\hline Height & 2 & \\
\hline
\end{tabular}


TABLE B.6 Parameters Describing the Landfill Future-Use Scenarios ${ }^{\mathrm{a}}$

\begin{tabular}{|c|c|c|}
\hline Parameter & Value & Remark \\
\hline Average radionuclide concentration (pCi/g) & 1 & Not applicable for off-site resident scenario. \\
\hline Dilution factor & 1 & $\begin{array}{l}\text { Calculated for intruder scenario from area, } \\
\text { intruded depth, and landfill cover depth. }\end{array}$ \\
\hline Groundwater concentration (pCi/L) & 0 & $\begin{array}{l}\text { Value will be calculated for off-site resident } \\
\text { scenario. }\end{array}$ \\
\hline Area $\left(\mathrm{m}^{2}\right)$ & 10,000 & $\begin{array}{l}\text { Assumed value for intruder scenario. Will be } \\
\text { estimated from the size of the landfill for } \\
\text { on-site resident, recreational, and industrial } \\
\text { scenarios. Not applicable for off-site resident } \\
\text { scenario. }\end{array}$ \\
\hline Density of waste layer $\left(\mathrm{g} / \mathrm{cm}^{3}\right)$ & 2 & Mixture of soil/TENORM (EPA 1993). \\
\hline Waste layer thickness & 0.92 & $\begin{array}{l}\text { Assumed value for intruder scenario and will be } \\
\text { estimated from the total volume of TENORM } \\
\text { waste disposed of for on-site resident, } \\
\text { recreational, and industrial scenarios. Not } \\
\text { applicable for off-site resident scenario. }\end{array}$ \\
\hline Cover depth (cm) & 0 & $\begin{array}{l}\text { Assumed value for intruder scenario. Will be } \\
\text { estimated from the landfill characteristics for } \\
\text { on-site resident, recreational, and industrial } \\
\text { scenarios. Not applicable for off-site resident } \\
\text { scenario. }\end{array}$ \\
\hline Density of cap material $\left(\mathrm{g} / \mathrm{cm}^{3}\right)$ & 1.6 & \\
\hline \multicolumn{3}{|l|}{ Plant/soil transfer factor } \\
\hline Radium & $6.8 \times 10^{-5}$ & A\&A (1996) \\
\hline Lead & $3.3 \times 10^{-5}$ & A\&A (1996) \\
\hline Thorium & $1.7 \times 10^{-6}$ & A\&A (1996) \\
\hline Uranium & 0.025 & RESRAD code default \\
\hline \multicolumn{3}{|l|}{ Exposure time $(\mathrm{h} / \mathrm{d})$} \\
\hline \multicolumn{3}{|l|}{ Residential } \\
\hline Indoor & 12 & Scenario assumption \\
\hline Outdoor & 6 & Scenario assumption \\
\hline \multicolumn{3}{|l|}{ Industrial } \\
\hline Indoor & 6 & Scenario assumption \\
\hline Outdoor & 2 & Scenario assumption \\
\hline \multicolumn{3}{|l|}{ Recreational } \\
\hline Indoor & 0 & Scenario assumption \\
\hline Outdoor & 1 & Scenario assumption \\
\hline \multicolumn{3}{|l|}{ Inhalation rate $\left(\mathrm{m}^{3} / \mathrm{yr}\right)$} \\
\hline On-site resident & 8,400 & Table 2.3 in RESRAD Manual \\
\hline On-site industrial worker & 11,400 & Table 2.3 in RESRAD Manual \\
\hline
\end{tabular}


TABLE B.6 (Cont.)

\begin{tabular}{|c|c|c|}
\hline Parameter & Value & Remark \\
\hline Recreational visitor & 14,000 & Table 2.3 in RESRAD Manual \\
\hline Off-site resident & 8,400 & Table 2.3 in RESRAD Manual \\
\hline \multicolumn{3}{|l|}{ Soil ingestion rates $(\mathrm{mg} / \mathrm{d})$} \\
\hline On-site resident & 100 & Table 2.3 in RESRAD Manual \\
\hline On-site industrial worker & 100 & Table 2.3 in RESRAD Manual \\
\hline Recreational visitor & 100 & Table 2.3 in RESRAD Manual \\
\hline Off-site resident & $\mathrm{NA}^{\mathrm{b}}$ & \\
\hline Erosion rate $(\mathrm{mm} / \mathrm{yr})$ & 1 & RESRAD code default \\
\hline Non-leafy vegetable productivity $\left(\mathrm{kg} / \mathrm{m}^{2}\right)$ & 0.7 & RESRAD code default \\
\hline Leafy vegetable productivity $\left(\mathrm{kg} / \mathrm{m}^{2}\right)$ & 1.5 & RESRAD code default \\
\hline Fodder productivity $\left(\mathrm{kg} / \mathrm{m}^{2}\right)$ & 1.1 & RESRAD code default \\
\hline Milk intake (L/yr) & 92 & RESRAD code default \\
\hline Fruit, vegetable, and grain consumption $(\mathrm{kg} / \mathrm{yr})$ & 160 & RESRAD code default \\
\hline Leafy vegetable consumption $(\mathrm{kg} / \mathrm{yr})$ & 14 & RESRAD code default \\
\hline Meat intake $(\mathrm{kg} / \mathrm{yr})$ & 63 & RESRAD code default \\
\hline Water intake (L/yr) & 510 & RESRAD code default \\
\hline Type of home construction & Slab & Scenario assumption \\
\hline Type of office construction & Slab & Scenario assumption \\
\hline Precipitation rate $(\mathrm{m} / \mathrm{yr})$ & 0.39 & Site specific \\
\hline Evapotranspiration coefficient & 0.62 & Site specific \\
\hline Runoff coefficient & 0.06 & Site specific \\
\hline Wind speed $(\mathrm{m} / \mathrm{s})$ & 5.2 & Site specific \\
\hline Irrigation rate $(\mathrm{m} / \mathrm{yr})$ & 0.2 & RESRAD code default \\
\hline Livestock fodder intake for meat $(\mathrm{kg} / \mathrm{d})$ & 68 & RESRAD code default \\
\hline Livestock fodder intake for milk (kg/d) & 55 & RESRAD code default \\
\hline Livestock water intake for meat $(\mathrm{L} / \mathrm{d})$ & 50 & RESRAD code default \\
\hline Livestock water intake for milk (L/d) & 160 & RESRAD code default \\
\hline Livestock intake of soil $(\mathrm{kg} / \mathrm{d})$ & 0.5 & RESRAD code default \\
\hline Depth of soil mixing layer (m) & 0.15 & RESRAD code default \\
\hline Depth of roots $(\mathrm{m})$ & 0.9 & RESRAD code default \\
\hline \multicolumn{3}{|l|}{ Storage Times (d) } \\
\hline Fruits, non-leafy vegetables, and grains & 14 & RESRAD code default \\
\hline Leafy vegetables & 1 & RESRAD code default \\
\hline Milk & 1 & RESRAD code default \\
\hline Meat & 20 & RESRAD code default \\
\hline Livestock fodder & 45 & RESRAD code default \\
\hline Well water & 1 & RESRAD code default \\
\hline \multicolumn{3}{|l|}{ Radon-Specific Parameters } \\
\hline Cap total porosity $(\%)$ & 40 & RESRAD code default \\
\hline Cap volumetric water content (\%) & 5 & RESRAD code default \\
\hline Cap radon diffusion coefficient $\left(\mathrm{m}^{2} / \mathrm{s}\right)$ & $2 \times 10^{-6}$ & RESRAD code default \\
\hline Foundation thickness (m) & 0.15 & RESRAD code default \\
\hline Foundation density $\left(\mathrm{g} / \mathrm{cm}^{3}\right)$ & 2.4 & RESRAD code default \\
\hline Foundation total porosity & 0.1 & RESRAD code default \\
\hline Foundation volumetric water content & 0.3 & RESRAD code default \\
\hline Foundation radon diffusion coefficient $\left(\mathrm{m}^{2} / \mathrm{s}\right)$ & $3 \times 10^{-7}$ & RESRAD code default \\
\hline
\end{tabular}


TABLE B.6 (Cont.)

\begin{tabular}{lcl}
\hline \multicolumn{1}{c}{ Parameter } & Value & \multicolumn{1}{c}{ Remark } \\
\hline & $2 \times 10^{-6}$ & RESRAD code default \\
Waste diffusion coefficient $\left(\mathrm{m}^{2} / \mathrm{s}\right)$ & 2 & RESRAD code default \\
Vertical mixing thickness $(\mathrm{m})$ & 0.5 & RESRAD code default \\
Building air exchange rate $\left(\mathrm{h}^{-1}\right)$ & 2.5 & RESRAD code default \\
Building room height $(\mathrm{m})$ & -1 & RESRAD code default \\
Foundation depth below ground surface $(\mathrm{m})$ & 4 & Rood and Kendrick 1996 \\
Rn-222 emanation coefficient $(\%)$ & 15 & RESRAD code default \\
Rn-220 emanation coefficient $(\%)$ & & \\
\hline
\end{tabular}

a For the intruder scenario, the contamination configuration is different, but the exposure pathways and other parameters are the same as for the on-site resident scenario. Many parameters values listed are RESRAD defaults, more representative values were used, if available.

b $\quad \mathrm{NA}=$ not applicable.

Sources: A\&A (1996); Rood and Kendrick (1996); EPA (1993; Yu et al. (2001). 


\section{TABLE B.7 Parameters Used for the Transportation Risk Assessment}

\begin{tabular}{|c|c|c|}
\hline Parameter & Value & Source \\
\hline Number of shipments per year & 1,000 & $\begin{array}{l}\text { From the assumption that } 25,000 \text { tons/year } \\
\text { waste disposed of in Special Waste Landfill } \\
\text { divided by the maximum truck capacity of } \\
25 \text { tons }\end{array}$ \\
\hline Distance to landfill $(\mathrm{km})$ & 250 & Assumed distance \\
\hline Travel fraction rural & 0.865 & $\begin{array}{l}\text { Estimated from values in Table D-3 of } \\
\text { Weiner et al. (2013) }\end{array}$ \\
\hline Travel fraction suburban & 0.104 & \\
\hline Travel fraction urban & 0.031 & \\
\hline $\begin{array}{l}\text { Closest distance to nearby roads for a receptor } \\
\text { living near the waste disposal facility }(\mathrm{m})\end{array}$ & 300 & Default in the code \\
\hline Population density (persons $/ \mathrm{km}^{2}$ ) & & From 2010 Census data for North Dakota \\
\hline Rural & 1.5 & \\
\hline Suburban & 846 & \\
\hline $\begin{array}{l}\text { Traffic density (vehicles per hour) } \\
\text { Rural }\end{array}$ & 293 & $\begin{array}{l}\text { From value in Table D-3 of Weiner et al. } \\
\text { (2013) }\end{array}$ \\
\hline Suburban & 575 & \\
\hline Urban & 1,063 & \\
\hline Dose-rate $1 \mathrm{~m}$ from vehicle $(\mathrm{rem} / \mathrm{h})$ & $2.5 \times 10^{-5}$ & $\begin{array}{l}\text { Based on information from the state } \\
\text { (if available), otherwise value be estimated }\end{array}$ \\
\hline Trailer size $(\mathrm{m})$ & 8 & \\
\hline Truck velocity $(\mathrm{km} / \mathrm{h})$ & $88.49^{\mathrm{a}}$ & $\begin{array}{l}\text { Based on average speed }(55 \mathrm{mph}) \text { in rural } \\
\text { areas and freeways from Table } 6.11 \text { in DOE } \\
(2002)\end{array}$ \\
\hline Accident rate (accidents $/ \mathrm{km})$ & $3.4 \times 10^{-7}$ & $\begin{array}{l}\text { For North Dakota from Table } 6.20 \text { in DOE } \\
(2002)\end{array}$ \\
\hline \multicolumn{3}{|l|}{ Accident fatality rate (fatalities $/ \mathrm{km}$ ) } \\
\hline Rural & $1.1 \times 10^{-8}$ & 5-year average (2007-2011) \\
\hline Suburban & $4.4 \times 10^{-9}$ & NDDOT (2012) \\
\hline Vehicular emission fatality rate (fatalities $/ \mathrm{km}$ ) & $8.36 \times 10^{-10}$ & $\begin{array}{l}\text { Assuming Truck Class VIIB from Table } 6.41 \\
\text { in DOE (2002) }\end{array}$ \\
\hline
\end{tabular}

Sources: DOE (2002); NDDOT (2012); Weiner et al. (2013); U.S. Census Bureau (2014). 
TABLE B.8 Conditional Accident

Probabilities and Associated Release

Fraction by Accident Severity Category

\begin{tabular}{ccc}
\hline $\begin{array}{c}\text { Accident Severity } \\
\text { Category }\end{array}$ & $\begin{array}{c}\text { Conditional } \\
\text { Probability }\end{array}$ & $\begin{array}{c}\text { Release } \\
\text { Fraction }^{\text {a }}\end{array}$ \\
\hline I & 0.55 & 0 \\
II & 0.36 & 0.01 \\
III & 0.07 & 0.1 \\
IV & 0.02 & 1 \\
\hline
\end{tabular}

a Values are for the total material release fraction (the fraction of the material in a package released to the environment during an accident).

Source: NRC (1977).

\section{Appendix B References}

A\&A (Auxier and Associates, Inc.), 1996, Leachate Analysis of Martha Oil Field Wastes, Martha, KY, prepared for Ashland Exploration, Inc., Houston, TX.

DOE (U.S. Department of Energy), 2002, A Resource Handbook on DOE Transportation Risk Assessment, DOE/EM/NTP/HB-01, July.

EPA (U.S. Environmental Protection Agency), 1993, DRAFT Diffuse NORM Wastes-Waste Characterization and Preliminary Risk Assessment, RAE-9232/1-2, Vol. 1, prepared by S. Cohen and Associates, Inc., and Rogers \& Associates Engineering Corp. for the Office of Radiation and Indoor Air, Washington, DC.

NDDOT (North Dakota Department of Transportation), 2012, North Dakota Highway Safety Plan, 2013, prepared by the Safety Division, Traffic Safety Office, Sept. Available at http://www.dot.nd.gov/divisions/safety/docs/2013-HSP-Final.pdf.

NRC (U.S. Nuclear Regulatory Commission), 1977, Final Environmental Statement on the Transportation of Radioactive Material by Air and Other Modes, NUREG-0170, Dec.

Pfingston, M., et al., 1998, TSD-DOSE: A Radiological Dose Assessment Model for Treatment, Storage, and Disposal Facilities, ANL/EAD/LD-4 (Rev. 1), Argonne National Laboratory, Argonne, IL.

Rood, A.S., and D.T. Kendrick, 1996, "Measurement of 222Rn Flux, 222Rn Emanation, and 226Ra Concentration from Injection Well Pipe Scale," in NORM/NARM: Regulations and Risk Assessment, Proceedings of the 29th Midyear Topical Meeting of the Health Physics Society, Scottsdale, AZ, Jan. 7-10, pp. 139-144. 
Smith, K.P., D.L. Blunt, G.P. Williams, and C.L. Tebes, 1996, Radiological Dose Assessment Related to Management of Naturally Occurring Radioactive Materials Generated by the Petroleum Industry, ANL/EAD-2, Argonne National Laboratory, Argonne, IL.

U.S. Census Bureau, 2014, 2010 Census Urban Lists Record Layouts. Available at http://www.census.gov/geo/reference/ua/ualists_layout.html. Accessed May 21, 2014.

Weiner, R.F., et al., 2013, RADTRAN 6/RadCat 6 User Guide, SAND2013-8095, Sandia National Laboratories, Albuquerque, NM, and Livermore, CA, Sept.

Yu, C., et al., 2001, User's Manual for RESRAD, Version 6, ANL/EAD-4, Argonne National Laboratory, Argonne, IL. 
This page intentionally left blank.

$B-16$ 
APPENDIX C:

LANDFILL DESIGNS TESTED WITH THE HELP MODEL 
This page intentionally left blank.

C-2 


\section{TABLE C.1 Special Waste Landfill Design}

\begin{tabular}{|c|c|c|c|c|c|c|c|c|c|c|c|c|c|c|}
\hline \multicolumn{5}{|c|}{$\begin{array}{l}\text { Special Waste Landfill Open Cell } \\
\text { (Operational Phase) }\end{array}$} & \multicolumn{5}{|c|}{$\begin{array}{c}\text { Special Waste Landfill Capped Cell } \\
\text { (Post-Closure Phase and Sensitivity Test) }\end{array}$} & \multicolumn{5}{|c|}{ Special Waste Landfill Capped Cell (Degraded) } \\
\hline Layer & Thickness & $\begin{array}{l}\text { Material and } \\
\text { Requirement }\end{array}$ & $\begin{array}{c}\text { HELP } \\
\text { Model } \\
\text { Layer Type } \\
\end{array}$ & $\begin{array}{c}\text { HELP } \\
\text { Model } \\
\text { Material } \\
\end{array}$ & Layer & Thickness & $\begin{array}{l}\text { Material and } \\
\text { Requirement }\end{array}$ & $\begin{array}{c}\text { HELP } \\
\text { Model } \\
\text { Layer Type } \\
\end{array}$ & $\begin{array}{c}\text { HELP } \\
\text { Model } \\
\text { Material } \\
\end{array}$ & Layer & Thickness & $\begin{array}{l}\text { Material and } \\
\text { Requirement }\end{array}$ & $\begin{array}{c}\text { HELP } \\
\text { Model } \\
\text { Layer Type } \\
\end{array}$ & $\begin{array}{c}\text { HELP } \\
\text { Model } \\
\text { Material } \\
\end{array}$ \\
\hline & & & & & 1 & $0.5 \mathrm{ft}$ & Topsoil & $\begin{array}{l}\text { Vertical } \\
\text { percolation }\end{array}$ & $\begin{array}{l}\text { 9. Silty } \\
\text { loam }\end{array}$ & 1 & $0.5 \mathrm{ft}$ & Topsoil & $\begin{array}{l}\text { Vertical } \\
\text { percolation }\end{array}$ & $\begin{array}{l}\text { 9. Silty } \\
\text { loam }\end{array}$ \\
\hline & & & & & 2 & $1 \mathrm{ft}$ & Clayey soil & $\begin{array}{l}\text { Vertical } \\
\text { percolation }\end{array}$ & 8. Loam & 2 & $1 \mathrm{ft}$ & Clayey soil & $\begin{array}{l}\text { Vertical } \\
\text { percolation }\end{array}$ & 8. Loam \\
\hline & & & & & 3 & $1.5 \mathrm{ft}$ & $\begin{array}{l}\text { Recompacted soil, } \\
\mathrm{K}<1 \mathrm{e}-7 \mathrm{~cm} / \mathrm{s}\end{array}$ & Barrier soil & $\begin{array}{l}16 . \\
\text { Barrier } \\
\text { soil }\end{array}$ & 3 & $1.5 \mathrm{ft}$ & $\begin{array}{l}\text { Recompacted } \\
\text { soil, } \\
\mathrm{K}<1 \mathrm{e}-7 \mathrm{~cm} / \mathrm{s}\end{array}$ & Barrier soil & $\begin{array}{l}\text { 16. Barrier } \\
\text { soil }\end{array}$ \\
\hline 1 & $62.5 \mathrm{ft}$ & Waste & $\begin{array}{l}\text { Vertical } \\
\text { percolation }\end{array}$ & $\begin{array}{l}18 . \\
\text { Municipal } \\
\text { waste }\end{array}$ & 4 & $125 \mathrm{ft}$ & Waste & $\begin{array}{l}\text { Vertical } \\
\text { percolation }\end{array}$ & $\begin{array}{l}18 . \\
\text { Municipal } \\
\text { waste }\end{array}$ & 4 & $125 \mathrm{ft}$ & Waste & $\begin{array}{l}\text { Vertical } \\
\text { percolation }\end{array}$ & $\begin{array}{l}18 . \\
\text { Municipal } \\
\text { waste }\end{array}$ \\
\hline 2 & $1 \mathrm{ft}$ & $\begin{array}{l}\text { Drainage layer, } \\
\mathrm{K} \geq 1 \mathrm{e}-3 \mathrm{~cm} / \mathrm{s} \\
\mathrm{T} \geq 3 \mathrm{e}-2 \mathrm{~cm}^{2} / \mathrm{s} \\
\text { Presumed LCS. }\end{array}$ & $\begin{array}{l}\text { Lateral } \\
\text { drainage }\end{array}$ & 2. Sand & 5 & $1 \mathrm{ft}$ & $\begin{array}{l}\text { Drainage layer, } \\
\mathrm{K} \geq 1 \mathrm{e}-3 \mathrm{~cm} / \mathrm{s} \\
\mathrm{T} \geq 3 \mathrm{e}-2 \mathrm{~cm}^{2} / \mathrm{s} \\
\text { Presumed LCS. }\end{array}$ & $\begin{array}{l}\text { Lateral } \\
\text { drainage }\end{array}$ & 2. Sand & 5 & $1 \mathrm{ft}$ & $\begin{array}{l}\text { Drainage layer, } \\
\mathrm{K} \geq 1 \mathrm{e}-3 \mathrm{~cm} / \mathrm{s} \\
\mathrm{T} \geq 3 \mathrm{e}-2 \mathrm{~cm}^{2} / \mathrm{s} \\
\text { Presumed LCS. }\end{array}$ & $\begin{array}{l}\text { Lateral } \\
\text { drainage } \\
\text { (no LCS in } \\
\text { one case) }\end{array}$ & 2. Sand \\
\hline 3 & $60 \mathrm{mil}$ & Geomembrane & $\begin{array}{l}\text { Geomem- } \\
\text { brane }\end{array}$ & 35. HDPE & 6 & 60 mil & Geomembrane & $\begin{array}{l}\text { Geomem- } \\
\text { brane }\end{array}$ & 35. HDPE & & & & & \\
\hline 4 & $3 \mathrm{ft}$ & $\begin{array}{l}\text { Recompacted } \\
\text { clay, } \\
\mathrm{K}<1 \mathrm{e}-7 \mathrm{~cm} / \mathrm{s}\end{array}$ & Barrier soil & $\begin{array}{l}\text { 16. Barrier } \\
\text { soil }\end{array}$ & 7 & $3 \mathrm{ft}$ & $\begin{array}{l}\text { Recompacted clay, } \\
\mathrm{K}<1 \mathrm{e}-7 \mathrm{~cm} / \mathrm{s}\end{array}$ & Barrier soil & $\begin{array}{l}16 . \\
\text { Barrier } \\
\text { soil }\end{array}$ & 6 & $3 \mathrm{ft}$ & $\begin{array}{l}\text { Recompacted } \\
\text { clay, } \\
\mathrm{K}<1 \mathrm{e}-7 \mathrm{~cm} / \mathrm{s}\end{array}$ & Barrier soil & $\begin{array}{l}\text { 16. Barrier } \\
\text { soil }\end{array}$ \\
\hline 5 & $66 \mathrm{ft}$ & $\begin{array}{l}\text { Native soil } \\
\text { unsaturated zone }\end{array}$ & $\begin{array}{l}\text { Vertical } \\
\text { percolation }\end{array}$ & $\begin{array}{l}\text { 4. Loamy } \\
\text { sand }\end{array}$ & 8 & $66 \mathrm{ft}$ & $\begin{array}{l}\text { Native soil } \\
\text { unsaturated zone }\end{array}$ & $\begin{array}{l}\text { Vertical } \\
\text { percolation }\end{array}$ & $\begin{array}{l}\text { 4. Loamy } \\
\text { sand }\end{array}$ & 7 & $66 \mathrm{ft}$ & $\begin{array}{l}\text { Native soil } \\
\text { unsaturated zone }\end{array}$ & $\begin{array}{l}\text { Vertical } \\
\text { percolation }\end{array}$ & $\begin{array}{l}\text { 4. Loamy } \\
\text { sand }\end{array}$ \\
\hline
\end{tabular}

Abbreviations: $\mathrm{HDPE}=$ high-density polyethylene $; \mathrm{LCS}=$ leachate collection system. 


\section{TABLE C.2 Industrial Waste Landfill Design ${ }^{a}$}

\begin{tabular}{|c|c|c|c|c|c|c|c|c|c|c|c|c|c|c|}
\hline \multicolumn{5}{|c|}{$\begin{array}{l}\text { Industrial Waste Landfill Open Cell } \\
\text { (Operational Phase) }\end{array}$} & \multicolumn{5}{|c|}{$\begin{array}{c}\text { Industrial Waste Landfill Capped Cell } \\
\text { (Post-Closure Phase and Sensitivity Test) }\end{array}$} & \multicolumn{5}{|c|}{$\begin{array}{l}\text { Industrial Waste Landfill Capped Cell } \\
\text { (Degraded) }\end{array}$} \\
\hline Layer & Thickness & $\begin{array}{l}\text { Material and } \\
\text { Requirement }\end{array}$ & $\begin{array}{c}\text { HELP } \\
\text { Model } \\
\text { Layer Type }\end{array}$ & $\begin{array}{c}\text { HELP } \\
\text { Model } \\
\text { Material }\end{array}$ & Layer & Thickness & $\begin{array}{l}\text { Material and } \\
\text { Requirement }\end{array}$ & $\begin{array}{c}\text { HELP } \\
\text { Model } \\
\text { Layer Type }\end{array}$ & $\begin{array}{c}\text { HELP } \\
\text { Model } \\
\text { Material } \\
\end{array}$ & Layer & Thickness & $\begin{array}{l}\text { Material and } \\
\text { Requirement }\end{array}$ & $\begin{array}{c}\text { HELP } \\
\text { Model } \\
\text { Layer Type }\end{array}$ & $\begin{array}{c}\text { HELP } \\
\text { Model } \\
\text { Material }\end{array}$ \\
\hline & & & & & 1 & $3.5 \mathrm{ft}$ & Topsoil and soil & $\begin{array}{l}\text { Vertical } \\
\text { percolation }\end{array}$ & $\begin{array}{l}\text { 9. Silty } \\
\text { loam }\end{array}$ & 1 & $3.5 \mathrm{ft}$ & Topsoil and soil & $\begin{array}{l}\text { Vertical } \\
\text { percolation }\end{array}$ & $\begin{array}{l}\text { 9. Silty } \\
\text { loam }\end{array}$ \\
\hline & & & & & 2 & $1 \mathrm{ft}$ & $\begin{array}{l}\text { Drainage layer, } \\
\mathrm{K} \geq 1 \mathrm{e}-3 \mathrm{~cm} / \mathrm{s} \\
\mathrm{T} \geq 3 \mathrm{e}-2 \mathrm{~cm}^{2} / \mathrm{s} \\
\text { Presumed LCS }\end{array}$ & $\begin{array}{l}\text { Lateral } \\
\text { drainage }\end{array}$ & 2. Sand & 2 & $1 \mathrm{ft}$ & $\begin{array}{l}\text { Drainage layer, } \\
\mathrm{K} \geq 1 \mathrm{e}-3 \mathrm{~cm} / \mathrm{s} \\
\mathrm{T} \geq 3 \mathrm{e}-2 \mathrm{~cm}^{2} / \mathrm{s} \\
\text { Presumed LCS. }\end{array}$ & $\begin{array}{l}\text { Lateral } \\
\text { drainage } \\
\text { (no LCS in } \\
\text { one case) }\end{array}$ & 2. Sand \\
\hline & & & & & 3 & 60 mil & Geomembrane & $\begin{array}{l}\text { Geomem- } \\
\text { brane }\end{array}$ & 35. HDPE & & & & & \\
\hline & & & & & 4 & $2 \mathrm{ft}$ & $\begin{array}{l}\text { Compacted soil, } \\
\mathrm{K}<1 \mathrm{e}-7 \mathrm{~cm} / \mathrm{s}\end{array}$ & Barrier soil & $\begin{array}{l}\text { 14. Silty } \\
\text { clay }\end{array}$ & 3 & $2 \mathrm{ft}$ & $\begin{array}{l}\text { Compacted } \\
\text { soil, } \\
\mathrm{K}<1 \mathrm{e}-7 \mathrm{~cm} / \mathrm{s}\end{array}$ & Barrier soil & $\begin{array}{l}\text { 14. Silty } \\
\text { clay }\end{array}$ \\
\hline 1 & $62.5 \mathrm{ft}$ & Waste & $\begin{array}{l}\text { Vertical } \\
\text { percolation }\end{array}$ & $\begin{array}{l}18 . \\
\text { Municipal } \\
\text { waste }\end{array}$ & 5 & $125 \mathrm{ft}$ & Waste & $\begin{array}{l}\text { Vertical } \\
\text { percolation }\end{array}$ & $\begin{array}{l}18 . \\
\text { Municipal } \\
\text { waste }\end{array}$ & 4 & $125 \mathrm{ft}$ & Waste & $\begin{array}{l}\text { Vertical } \\
\text { percolation }\end{array}$ & $\begin{array}{l}18 . \\
\text { Municipal } \\
\text { waste }\end{array}$ \\
\hline 2 & $1 \mathrm{ft}$ & $\begin{array}{l}\text { Drainage layer, } \\
\mathrm{K} \geq 1 \mathrm{e}-3 \mathrm{~cm} / \mathrm{s}, \\
\mathrm{T} \geq 3 \mathrm{e}-2 \mathrm{~cm}^{2} / \mathrm{s}, \\
\text { therefore } \mathrm{b}= \\
32 \mathrm{~cm}=1 \mathrm{ft} . \\
\text { Presumed LCS. }\end{array}$ & $\begin{array}{l}\text { Lateral } \\
\text { drainage }\end{array}$ & 2. Sand & 6 & $1 \mathrm{ft}$ & $\begin{array}{l}\text { Drainage layer, } \\
\mathrm{K} \geq 1 \mathrm{e}-3 \mathrm{~cm} / \mathrm{s}, \\
\mathrm{T} \geq 3 \mathrm{e}-2 \mathrm{~cm}^{2} / \mathrm{s}, \\
\text { therefore } \mathrm{b}=32 \mathrm{~cm} \\
=1 \mathrm{ft} . \\
\text { Presumed LCS. }\end{array}$ & $\begin{array}{l}\text { Lateral } \\
\text { drainage }\end{array}$ & 2. Sand & 5 & $1 \mathrm{ft}$ & $\begin{array}{l}\text { Drainage layer, } \\
\mathrm{K} \geq 1 \mathrm{e}-3 \mathrm{~cm} / \mathrm{s} \\
\mathrm{T} \geq 3 \mathrm{e}-2 \mathrm{~cm}^{2} / \mathrm{s} \\
\text { therefore } \mathrm{b}= \\
32 \mathrm{~cm}=1 \mathrm{ft} . \\
\text { Presumed LCS. }\end{array}$ & $\begin{array}{l}\text { Lateral } \\
\text { drainage } \\
\text { (no LCS in } \\
\text { one case) }\end{array}$ & 2. Sand \\
\hline 3 & $80 \mathrm{mil}$ & Geomembrane & $\begin{array}{l}\text { Geomem- } \\
\text { brane }\end{array}$ & 35. HDPE & 7 & 80 mil & Geomembrane & $\begin{array}{l}\text { Geomem- } \\
\text { brane }\end{array}$ & 35. HDPE & & & & & \\
\hline 4 & $1 \mathrm{ft}$ & $\begin{array}{l}\text { Drainage layer, } \\
\mathrm{K} \geq 1 \mathrm{e}-3 \mathrm{~cm} / \mathrm{s} \\
\mathrm{T} \geq 3 \mathrm{e}-2 \mathrm{~cm}^{2} / \mathrm{s}\end{array}$ & $\begin{array}{l}\text { Lateral } \\
\text { drainage }\end{array}$ & 2. Sand & 8 & $1 \mathrm{ft}$ & $\begin{array}{l}\text { Drainage layer, } \\
\mathrm{K} \geq 1 \mathrm{e}-3 \mathrm{~cm} / \mathrm{s} \\
\mathrm{T} \geq 3 \mathrm{e}-2 \mathrm{~cm}^{2} / \mathrm{s}\end{array}$ & $\begin{array}{l}\text { Lateral } \\
\text { drainage }\end{array}$ & 2. Sand & 6 & $1 \mathrm{ft}$ & $\begin{array}{l}\text { Drainage layer, } \\
\mathrm{K} \geq 1 \mathrm{e}-3 \mathrm{~cm} / \mathrm{s} \\
\mathrm{T} \geq 3 \mathrm{e}-2 \mathrm{~cm}^{2} / \mathrm{s}\end{array}$ & $\begin{array}{l}\text { Lateral } \\
\text { drainage } \\
\text { (no LCS in } \\
\text { one case) }\end{array}$ & 2. Sand \\
\hline 5 & $60 \mathrm{mil}$ & Geomembrane & $\begin{array}{l}\text { Geomem- } \\
\text { brane }\end{array}$ & 35. HDPE & 9 & 60 mil & Geomembrane & $\begin{array}{l}\text { Geomem- } \\
\text { brane }\end{array}$ & 35. HDPE & & & & & \\
\hline
\end{tabular}


TABLE C.2 (Cont.)

\begin{tabular}{|c|c|c|c|c|c|c|c|c|c|c|c|c|c|c|}
\hline \multicolumn{5}{|c|}{$\begin{array}{l}\text { Industrial Waste Landfill Open Cell } \\
\text { (Operational phase) }\end{array}$} & \multicolumn{5}{|c|}{$\begin{array}{l}\text { Industrial Waste Landfill Capped Cell } \\
\text { (Post-closure phase and Sensitivity test) }\end{array}$} & \multicolumn{5}{|c|}{$\begin{array}{c}\text { Industrial Waste Landfill Capped Cell } \\
\text { (degraded) }\end{array}$} \\
\hline Layer & Thickness & $\begin{array}{l}\text { Material and } \\
\text { Requirement }\end{array}$ & $\begin{array}{c}\text { HELP } \\
\text { Model } \\
\text { Layer Type }\end{array}$ & $\begin{array}{l}\text { HELP } \\
\text { Model } \\
\text { Material }\end{array}$ & Layer & Thickness & $\begin{array}{l}\text { Material and } \\
\text { Requirement }\end{array}$ & $\begin{array}{c}\text { HELP } \\
\text { Model } \\
\text { Layer Type }\end{array}$ & $\begin{array}{l}\text { HELP } \\
\text { Model } \\
\text { Material }\end{array}$ & Layer & Thickness & $\begin{array}{l}\text { Material and } \\
\text { Requirement }\end{array}$ & $\begin{array}{c}\text { HELP } \\
\text { Model } \\
\text { Layer Type }\end{array}$ & $\begin{array}{r}\text { HELP } \\
\text { Model } \\
\text { Materia }\end{array}$ \\
\hline 6 & $3 \mathrm{ft}$ & $\begin{array}{l}\text { Recompacted } \\
\text { clay, } \\
\mathrm{K}<1 \mathrm{e}-7 \mathrm{~cm} / \mathrm{s}\end{array}$ & Barrier soil & $\begin{array}{l}\text { 16. Barrier } \\
\text { soil }\end{array}$ & 10 & $3 \mathrm{ft}$ & $\begin{array}{l}\text { Recompacted clay, } \\
\mathrm{K}<1 \mathrm{e}-7 \mathrm{~cm} / \mathrm{s}\end{array}$ & Barrier soil & $\begin{array}{l}\text { 16. Barrier } \\
\text { soil }\end{array}$ & 7 & $3 \mathrm{ft}$ & $\begin{array}{l}\text { Recompacted } \\
\text { clay, } \\
\mathrm{K}<1 \mathrm{e}-7 \mathrm{~cm} / \mathrm{s}\end{array}$ & Barrier soil & $\begin{array}{l}\text { 16. Barrier } \\
\text { soil }\end{array}$ \\
\hline 7 & $66 \mathrm{ft}$ & $\begin{array}{l}\text { Native soil } \\
\text { unsaturated zone }\end{array}$ & $\begin{array}{l}\text { Vertical } \\
\text { percolation }\end{array}$ & $\begin{array}{l}\text { 4. Loamy } \\
\text { sand }\end{array}$ & 11 & $66 \mathrm{ft}$ & $\begin{array}{l}\text { Native soil } \\
\text { unsaturated zone }\end{array}$ & $\begin{array}{l}\text { Vertical } \\
\text { percolation }\end{array}$ & $\begin{array}{l}\text { 4. Loamy } \\
\text { sand }\end{array}$ & 8 & $66 \mathrm{ft}$ & $\begin{array}{l}\text { Native soil } \\
\text { unsaturated zone }\end{array}$ & $\begin{array}{l}\text { Vertical } \\
\text { percolation }\end{array}$ & $\begin{array}{l}\text { 4. Loamy } \\
\text { sand }\end{array}$ \\
\hline
\end{tabular}

Abbreviations: HDPE = high-density polyethylene; $\mathrm{LCS}=$ leachate collection system.

${ }^{a}$ Each drainage layer's thickness is calculated as the required transmissivity $(\mathrm{T})$ divided by the required hydraulic conductivity $(\mathrm{K})$ and is approximately $1 \mathrm{ft}$. 
This page intentionally left blank. 
APPENDIX D:

LITERATURE REVIEW OF THE DISTRIBUTION COEFFICIENT KD 
This page intentionally left blank.

D-2 


\section{APPENDIX D:}

\section{LITERATURE REVIEW OF THE DISTRIBUTION COEFFICIENT KD}

\section{D.1 $K_{d}$ of Radium}

Auxier \& Associates (A\&A) (1996) performed leaching analyses on radium-226 (Ra-226)-containing materials using the toxicity characteristic leaching procedure (TCLP). Samples included naturally occurring radioactive material (NORM) pipe scale and NORMcontaminated soil associated with oil field wastes in Kentucky. The scale samples were crushed to promote a worst-case leaching scenario. Table C.1 shows the results for the scale and soil samples. The activity leached fraction (LF) was calculated by A\&A (1996) as the amount of Ra-226 in the leachate divided by the total amount of Ra-226 in the leachate plus Ra-226 residual on the solid sample. The LF ranges from $2.5 \times 10^{-4}$ to $4.1 \times 10^{-3}$ (Table D.1).

A\&A (1996) used the TCLP results to estimate the distribution coefficient, $K_{d}$, by equating it to the ratio of the residue activity concentration to the leachate activity concentration. Because of the differences in the TCLP method compared with the traditional batch test method for $\mathrm{K}_{\mathrm{d}}$, the TCLP method differs in terms of the solution-to-solid ratio and the acidity of the liquid phase, and the $K_{d}$ is expected to be underestimated (A\&A 1996). This $K_{d}: L F$ relationship is illustrated in Figure D.1.

A report by Swann et al. (2004) includes analysis of leaching of radium from NORM scale and sludge samples. In this case, the maximum LF was $1.1 \times 10^{-3}$ for NORM-containing tank sludge, while the LF from a mixture of NORM and soil was $3.6 \times 10^{-3}$. These are in the same range of the LFs determined by A\&A (1996). Swann et al. (2004) note that soils have the ability to complex soluble radium, which results in higher LFs for scale-soil mixtures than for pure scale. This is supported by the data from both A\&A (1996) and Swann et al. (2004).

The U.S. Environmental Protection Agency (EPA) (2004) has summarized the work of numerous publications on the $\mathrm{K}_{\mathrm{d}}$ values of radium. Limited data are available, and very high apparent adsorption may be due to the precipitation of $(\mathrm{Ba}, \mathrm{Ra}) \mathrm{SO}_{4}$ during experiments. The EPA recommends site-specific conditions for $\mathrm{K}_{\mathrm{d}}$ testing. Radium sorption may depend on the $\mathrm{pH}$ of the system. Summarized findings from the literature about radium sorption on soils include the following:

- $\quad \mathrm{K}_{\mathrm{d}}$ values of $6.7,12.6,26.3$, and $26.3 \mathrm{~mL} / \mathrm{g}$ on sandy material at $\mathrm{pH}$ values of $6,7,8$, and 9, respectively, and desorption $\mathrm{Kd}$ values of 10.9, 31, 38, and $29 \mathrm{~mL} / \mathrm{g}$ at the same $\mathrm{pH}$ levels, indicating that adsorption and desorption of radium increase with increasing $\mathrm{pH}$, and that radium essentially undergoes complete reversible adsorption.

- $\mathrm{K}_{\mathrm{d}}$ values of 214 to $467 \mathrm{~mL} / \mathrm{g}$ on sandy soil samples with a $\mathrm{pH}$ of 7.6 to 8.0. 
TABLE D.1 Ra-226 Leached Fraction and $K_{d}$ of Samples Containing Ra-226

\begin{tabular}{|c|c|c|c|c|c|c|c|c|c|}
\hline & & $\mathrm{A}$ & $\mathrm{B}$ & $\mathrm{C}=\mathrm{B} * 2$ & $\mathrm{D}$ & $E=D * 100$ & $\mathrm{C} /(\mathrm{C}+\mathrm{E})$ & $1,000 * \mathrm{~B} / \mathrm{D}$ & \\
\hline Sample & Description & $\begin{array}{c}\text { Sample's } \\
\text { Ra-226* } \\
(\mathrm{pCi} / \mathrm{g})\end{array}$ & $\begin{array}{c}\text { TCLP Ra-226 } \\
\text { Concentration } \\
\text { in } 2 \mathrm{~L} \text { of } \\
\text { Leachate* } \\
(\mathrm{pCi} / \mathrm{L})\end{array}$ & $\begin{array}{l}\text { Amount of } \\
\text { Ra-226 in } \\
\text { Leachate } \\
\text { (pCi) }\end{array}$ & $\begin{array}{c}\text { TCLP } \\
\text { Residue in } \\
100 \mathrm{~g} \\
\text { Sample* } \\
(\mathrm{pCi} / \mathrm{g})\end{array}$ & $\begin{array}{l}\text { Amount of } \\
\text { Ra-226 in } \\
\text { Residue } \\
\text { (pCi) }\end{array}$ & $\mathrm{LF}$ & $\mathrm{K}_{\mathrm{d}}(\mathrm{mL} / \mathrm{g})$ & $\begin{array}{c}\text { Average } \\
\mathrm{K}_{\mathrm{d}}(\mathrm{mL} / \mathrm{g})\end{array}$ \\
\hline SCHS004 & Soil near tanks & 75 & 9 & 17 & 62 & 6,200 & $2.73 \times 10^{-3}$ & 7,294 & \multirow{2}{*}{6,102} \\
\hline SCHS002 & Soil near tanks & 110 & 11 & 22 & 54 & 5,400 & $4.06 \times 10^{-3}$ & 4,909 & \\
\hline SCHS003 & Soil downgradient of tanks & 920 & 71 & 142 & 1,000 & 100,000 & $1.42 \times 10^{-3}$ & 14,085 & \multirow{2}{*}{25,561} \\
\hline SCHS001 & Soil downgradient of tanks & 1,100 & 27 & 54 & 1,000 & 100,000 & $5.4 \times 10^{-4}$ & 37,037 & \\
\hline $\mathrm{SCHC} 001$ & Scale of 1 pipe & 1,600 & 15 & 30 & 1,200 & 120,000 & $2.5 \times 10^{-4}$ & 80,000 & \multirow{3}{*}{79,286} \\
\hline $\mathrm{SCHC} 002$ & Scale of 7 pipes & 1,500 & 14 & 28 & 1,100 & 110,000 & $2.54 \times 10^{-4}$ & 78,571 & \\
\hline $\mathrm{SCHC} 003$ & Scale of 3 pipes & 1,700 & $<0.6$ & Ignored & 2,000 & 200,000 & Ignored & Ignored & \\
\hline
\end{tabular}

* Uncertainty estimates not shown.

Source: Data from A\&A (1996). 
- $\mathrm{K}_{\mathrm{d}}$ values at one site of 10 to $1,000,000 \mathrm{~mL} / \mathrm{g}$, with a recommended value of $100 \mathrm{~mL} / \mathrm{g}$.

- A cited compilation of multiple studies listed $K_{d}$ values for various soil types (but geochemical conditions were not documented):

- Sand: 57 to $21,000 \mathrm{~mL} / \mathrm{g}$, geometric mean $500 \mathrm{~mL} / \mathrm{g}, 3$ observations

- Silt: 1,262 to $530,000 \mathrm{~mL} / \mathrm{g}$, geometric mean $36,000 \mathrm{~mL} / \mathrm{g}, 3$ observations

- Clay: 696 to $56,000 \mathrm{~mL} / \mathrm{g}$, geometric mean $9,100 \mathrm{~mL} / \mathrm{g}, 8$ observations

- Organic soil: $2,400 \mathrm{~mL} / \mathrm{g}, 1$ observation.

Vandenhove et al. (2009) also provided a compilation of literature values, including many of those included by the EPA (2004). They determined a geometric mean $\mathrm{K}_{\mathrm{d}}$ of Ra-226 of $2,500 \mathrm{~mL} / \mathrm{g}$ based on 51 samples from various soil types. The variability among different soil types was large and ranges were overlapping. No other parameter $(\mathrm{pH}$, cation exchange capacity, or organic matter) was found to be useful in refining $\mathrm{K}_{\mathrm{d}}$ values for Ra-226.

The assumed $\mathrm{K}_{\mathrm{d}}$ of a landfilled waste-soil mixture and the assumed activity concentration of the mixture can be used to estimate a solute concentration. Knowing the presumed North Dakota landfill disposal concentration (and rounding up to be conservative) and assuming a conservatively high LF with an associated conservatively low $\mathrm{K}_{\mathrm{d}}$ (see Figure D.1), the dissolved concentration of Ra-226 can be estimated. Note that although some literature $\mathrm{K}_{\mathrm{d}}$ values for radium have been in the tens to hundreds of $\mathrm{mL} / \mathrm{g}$, most are in the thousands or higher. The A\&A data (Figure D.1) suggest that the $\mathrm{K}_{\mathrm{d}}$ of Ra-226 is fairly stable with assumed higher LF levels.

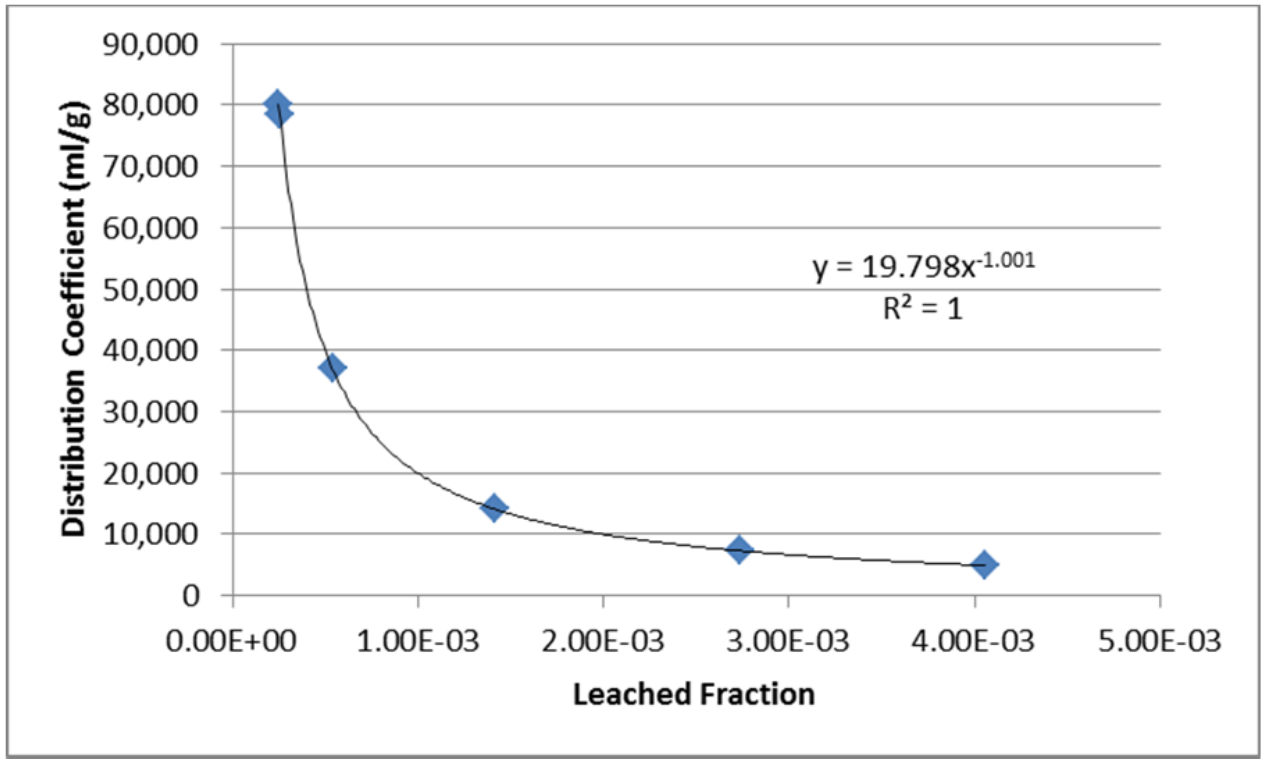

FIGURE D.1 Relationship between $K_{d}$ and Leached Fraction of Ra-226 Samples (Source: A\&A 1996) 


\section{D.2 $K_{d}$ of Thorium}

Vandenhove et al. (2009) compiled data on 46 measurements of the $K_{d}$ of thorium in various soils. The overall geometric mean was $1,900 \mathrm{~mL} / \mathrm{g}$ with a range of 19 to $250,000 \mathrm{~mL} / \mathrm{g}$. They note that the high values may be due to precipitation of thorium compounds. Following an EPA method that incorporates $\mathrm{pH}$ in the categorizing of $\mathrm{K}_{\mathrm{d}}$ values, they proposed values of $1,000 \mathrm{~mL} / \mathrm{g}$ for $\mathrm{pH}$ less than $5,3,000$ for $\mathrm{pH}$ from 5 to 8 , and 300 for $\mathrm{pH}$ greater than 8 . The EPA (2004) reported a similar range and $\mathrm{pH}$ bins.

\section{D.3 $K_{d}$ of Lead}

Vandenhove et al. (2009) compiled data on 23 measurements of the $K_{d}$ of lead in various soils. Very little information was found to be available on the $\mathrm{K}_{\mathrm{d}}$ of lead radioisotopes. The overall geometric mean was $2,100 \mathrm{~mL} / \mathrm{g}$ with a range of 25 to $127,000 \mathrm{~mL} / \mathrm{g}$. The values of $\mathrm{pH}$ were determined to influence the $\mathrm{K}_{\mathrm{d}}$ values. Data in the range of 3 to $6.4 \mathrm{pH}$ units had a geometric mean of $570 \mathrm{~mL} / \mathrm{g}$, while data in the range of 6.4 to $8.3 \mathrm{~mL} / \mathrm{g}$ had a geometric mean of $7,900 \mathrm{~mL} / \mathrm{g}$.

\section{D.4 $\mathbf{K}_{\mathrm{d}}$ Summary}

The studies described here provide a wide range of $K_{d}$ values for Ra-226, ranging from approximately 10 to $500,000 \mathrm{~mL} / \mathrm{g}$, with similar large ranges for the other radioisotopes. The results may depend on methods, $\mathrm{pH}$ (mainly in the case of thorium), other geochemical conditions, and soil type (or whether the sample is pure scale). In the absence of site-specific $\mathrm{K}_{\mathrm{d}}$ or leaching studies, conservative estimates (i.e., promoting high concentrations) may be made. The dissolved concentration value $\left(\mathrm{C}_{\text {solute }}\right)$ leaking from a landfill should be estimated for radium and thorium using a rounded-up value for the disposal activity concentration (assumed $\mathrm{C}^{*}$ ) and $\mathrm{K}_{\mathrm{d}}$ values of $100,1,000$, and $10,000 \mathrm{~mL} / \mathrm{g}$ so that the sensitivity of the source concentration can be explored. For lead, $\mathrm{K}_{\mathrm{d}}$ values of 10,100 , and $1,000 \mathrm{~mL} / \mathrm{g}$ should be examined.

\section{Appendix D References}

A\&A (Auxier and Associates, Inc.), 1996, Leachate Analysis of Martha Oil Field Wastes, Martha, KY, prepared for Ashland Exploration, Inc., Houston, TX.

EPA (U.S. Environmental Protection Agency), 2004, "Understanding Variation in Partition Coefficient, $\mathrm{K}_{\mathrm{d}}$, Values," in Volume III: Review of Geochemistry and Available $K_{d}$ Values for Americium, Arsenic, Curium, Iodine, Neptunium, Radium, and Technetium, EPA 402-R-04002C, Washington, DC, July. 
Swann, C., J. Matthews, R. Ericksen, and J. Kuszmaul, 2004, Evaluations of Radionuclides of Uranium, Thorium, and Radium Associated with Produced Fluids, Precipitates, and Sludges from Oil, Gas, and Oilfield Brine Injections Wells in Mississippi, Final Report, U.S. Department of Energy Award Number DE-FG26-02NT 15227, March.

Vandenhove, H., G. Gil-Garcia, A. Rigol, and M. Vidal, 2009, "New Best Estimates for Radionuclide Solid-Liquid Distribution Coefficients in Soils. Part 2. Naturally Occurring Radionuclides," Journal of Environmental Radioactivity 100:697-703. 
This page intentionally left blank. 
APPENDIX E:

GROUNDWATER CALCULATIONS 
This page intentionally left blank.

E-2 
TABLE E.1 Calculations Relating Disposal Concentration of Unity, Appropriate Range of In-Landfill $K_{d}$ Values, Leachate Concentration Reaching Water Table, Downgradient Proportion of Leachate Recharge, and Concentration in Groundwater for 100-m (328-ft) Downgradient Receptor and 20-m (66-ft) Thick Unsaturated Zone

\begin{tabular}{|c|c|c|c|c|c|c|c|c|c|c|c|c|c|c|c|c|c|}
\hline \multirow[t]{3}{*}{ Note A } & \multirow{3}{*}{$\begin{array}{c}\text { Note B } \\
\begin{array}{c}\mathrm{K}_{\mathrm{d}} \\
(\mathrm{mL} / \mathrm{g})\end{array}\end{array}$} & \multicolumn{16}{|c|}{ Max. C/Co and Max. Conc. in 10,000 Years at 100-m Downgradient Receptor } \\
\hline & & \multicolumn{2}{|c|}{ LF leachate } & \multirow{2}{*}{$\begin{array}{c}\text { Decay } \\
\text { Const. } \\
1 / \mathrm{yr} \\
\end{array}$} & \multirow{2}{*}{$\begin{array}{c}\text { Conc. at } \\
\text { Water } \\
\text { Table } \\
\text { pCi/L }\end{array}$} & \multicolumn{2}{|c|}{ Base Case } & \multicolumn{2}{|c|}{ Decreased $K_{d}$} & \multicolumn{2}{|c|}{ Increased $\mathrm{K}_{\mathrm{d}}$} & \multicolumn{2}{|c|}{$\begin{array}{c}\text { Increased } \\
\text { Dispersivity }\end{array}$} & \multicolumn{2}{|c|}{ Increased Gradient } & \multicolumn{2}{|c|}{$\begin{array}{c}\text { Increased Hydraulic } \\
\text { Conductivity }\end{array}$} \\
\hline & & $\begin{array}{l}\mathrm{C}_{\text {solute }} \\
\mathrm{pCi} / \mathrm{mL}\end{array}$ & $\begin{array}{l}\mathrm{C}_{\text {solute }} \\
\mathrm{pCi} / \mathrm{L}\end{array}$ & & & $\mathrm{C} / \mathrm{Co}$ & $\mathrm{pCi} / \mathrm{L}$ & $\mathrm{C} / \mathrm{Co}$ & $\mathrm{pCi} / \mathrm{L}$ & $\mathrm{C} / \mathrm{Co}$ & $\mathrm{pCi} / \mathrm{L}$ & $\mathrm{C} / \mathrm{Co}$ & $\mathrm{pCi} / \mathrm{L}$ & $\mathrm{C} / \mathrm{Co}$ & $\mathrm{pCi} / \mathrm{L}$ & $\mathrm{C} / \mathrm{Co}$ & $\mathrm{pCi} / \mathrm{L}$ \\
\hline $\mathrm{Pb}-210$ & $\begin{array}{r}1,000 \\
100 \\
10\end{array}$ & $\begin{array}{r}0.001 \\
0.01 \\
0.1\end{array}$ & $\begin{array}{r}1 \\
10 \\
100\end{array}$ & $\begin{array}{l}0.031 \\
0.031 \\
0.031\end{array}$ & $\begin{array}{r}0.15 \\
1.5 \\
15\end{array}$ & $\begin{array}{l}7.88 \mathrm{E}-13 \\
7.88 \mathrm{E}-13 \\
7.88 \mathrm{E}-13\end{array}$ & $\begin{array}{l}1.21 \mathrm{E}-13 \\
1.21 \mathrm{E}-12 \\
1.21 \mathrm{E}-11\end{array}$ & $\begin{array}{l}2.89 \mathrm{E}-07 \\
2.89 \mathrm{E}-07 \\
2.89 \mathrm{E}-07\end{array}$ & $\begin{array}{l}4.44 \mathrm{E}-08 \\
4.44 \mathrm{E}-07 \\
4.44 \mathrm{E}-06\end{array}$ & $\begin{array}{l}6.14 \mathrm{E}-19 \\
6.14 \mathrm{E}-19 \\
6.14 \mathrm{E}-19\end{array}$ & $\begin{array}{l}9.44 \mathrm{E}-20 \\
9.44 \mathrm{E}-19 \\
9.44 \mathrm{E}-18\end{array}$ & $\begin{array}{l}1.05 \mathrm{E}-09 \\
1.05 \mathrm{E}-09 \\
1.05 \mathrm{E}-09\end{array}$ & $\begin{array}{l}1.61 \mathrm{E}-10 \\
1.61 \mathrm{E}-09 \\
1.61 \mathrm{E}-08\end{array}$ & $\begin{array}{l}1.27 \mathrm{E}-11 \\
1.27 \mathrm{E}-11 \\
1.27 \mathrm{E}-11\end{array}$ & $\begin{array}{l}1.96 \mathrm{E}-12 \\
1.96 \mathrm{E}-11 \\
1.96 \mathrm{E}-10\end{array}$ & $\begin{array}{l}1.34 \mathrm{E}-07 \\
1.34 \mathrm{E}-07 \\
1.34 \mathrm{E}-07\end{array}$ & $\begin{array}{l}2.06 \mathrm{E}-08 \\
2.06 \mathrm{E}-07 \\
2.06 \mathrm{E}-06\end{array}$ \\
\hline Ra-226 & $\begin{array}{r}10,000 \\
1,000 \\
100\end{array}$ & $\begin{array}{r}0.0001 \\
0.001 \\
0.01\end{array}$ & $\begin{array}{r}0.1 \\
1 \\
10\end{array}$ & $\begin{array}{l}0.00043 \\
0.00043 \\
0.00043\end{array}$ & $\begin{array}{r}0.097 \\
0.97 \\
9.7\end{array}$ & $\begin{array}{l}1.45 \mathrm{E}-08 \\
1.45 \mathrm{E}-08 \\
1.45 \mathrm{E}-08\end{array}$ & $\begin{array}{l}1.42 \mathrm{E}-09 \\
1.42 \mathrm{E}-08 \\
1.42 \mathrm{E}-07\end{array}$ & $\begin{array}{l}3.69 \mathrm{E}-07 \\
3.69 \mathrm{E}-07 \\
3.69 \mathrm{E}-07\end{array}$ & $\begin{array}{l}3.60 \mathrm{E}-08 \\
3.60 \mathrm{E}-07 \\
3.60 \mathrm{E}-06\end{array}$ & $\begin{array}{l}9.64 \mathrm{E}-14 \\
9.64 \mathrm{E}-14 \\
9.64 \mathrm{E}-14\end{array}$ & $\begin{array}{l}9.39 \mathrm{E}-15 \\
9.39 \mathrm{E}-14 \\
9.39 \mathrm{E}-13\end{array}$ & $\begin{array}{l}6.53 \mathrm{E}-06 \\
6.53 \mathrm{E}-06 \\
6.53 \mathrm{E}-06\end{array}$ & $\begin{array}{l}6.36 \mathrm{E}-07 \\
6.36 \mathrm{E}-06 \\
6.36 \mathrm{E}-05\end{array}$ & $\begin{array}{l}2.05 \mathrm{E}-07 \\
2.05 \mathrm{E}-07 \\
2.05 \mathrm{E}-07\end{array}$ & $\begin{array}{l}1.99 \mathrm{E}-08 \\
1.99 \mathrm{E}-07 \\
1.99 \mathrm{E}-06\end{array}$ & $\begin{array}{l}1.30 \mathrm{E}-04 \\
1.30 \mathrm{E}-04 \\
1.30 \mathrm{E}-04\end{array}$ & $\begin{array}{l}1.26 \mathrm{E}-05 \\
1.26 \mathrm{E}-04 \\
1.26 \mathrm{E}-03\end{array}$ \\
\hline Ra-228 & $\begin{array}{r}10,000 \\
1,000 \\
100\end{array}$ & $\begin{array}{r}0.0001 \\
0.001 \\
0.01\end{array}$ & $\begin{array}{r}0.1 \\
1 \\
10\end{array}$ & $\begin{array}{l}0.12 \\
0.12 \\
0.12\end{array}$ & $\begin{array}{r}7.2 \mathrm{E}-05 \\
0.00072 \\
0.0072\end{array}$ & $\begin{array}{l}3.06 \mathrm{E}-22 \\
3.06 \mathrm{E}-22 \\
3.06 \mathrm{E}-22\end{array}$ & $\begin{array}{l}2.21 \mathrm{E}-26 \\
2.21 \mathrm{E}-25 \\
2.21 \mathrm{E}-24\end{array}$ & $\begin{array}{l}1.92 \mathrm{E}-16 \\
1.92 \mathrm{E}-16 \\
1.92 \mathrm{E}-16\end{array}$ & $\begin{array}{l}1.39 \mathrm{E}-20 \\
1.39 \mathrm{E}-19 \\
1.39 \mathrm{E}-18\end{array}$ & $\begin{array}{l}4.57 \mathrm{E}-30 \\
4.57 \mathrm{E}-30 \\
4.57 \mathrm{E}-30\end{array}$ & $\begin{array}{l}3.30 \mathrm{E}-34 \\
3.30 \mathrm{E}-33 \\
3.30 \mathrm{E}-32\end{array}$ & $\begin{array}{l}1.61 \mathrm{E}-20 \\
1.61 \mathrm{E}-20 \\
1.61 \mathrm{E}-20\end{array}$ & $\begin{array}{l}1.16 \mathrm{E}-24 \\
1.16 \mathrm{E}-23 \\
1.16 \mathrm{E}-22\end{array}$ & $\begin{array}{l}4.68 \mathrm{E}-21 \\
4.68 \mathrm{E}-21 \\
4.68 \mathrm{E}-21\end{array}$ & $\begin{array}{l}3.38 \mathrm{E}-25 \\
3.38 \mathrm{E}-24 \\
3.38 \mathrm{E}-23\end{array}$ & $\begin{array}{l}1.59 \mathrm{E}-16 \\
1.59 \mathrm{E}-16 \\
1.59 \mathrm{E}-16\end{array}$ & $\begin{array}{l}1.15 \mathrm{E}-20 \\
1.15 \mathrm{E}-19 \\
1.15 \mathrm{E}-18\end{array}$ \\
\hline Th-232 & $\begin{array}{r}10,000 \\
1,000 \\
100 \\
\end{array}$ & $\begin{array}{r}0.0001 \\
0.001 \\
0.01 \\
\end{array}$ & $\begin{array}{r}0.1 \\
1 \\
10 \\
\end{array}$ & $\begin{array}{l}5 \mathrm{E}-11 \\
5 \mathrm{E}-11 \\
5 \mathrm{E}-11 \\
\end{array}$ & $\begin{array}{r}0.1 \\
1 \\
10 \\
\end{array}$ & $\begin{array}{l}5.59 \mathrm{E}-07 \\
5.59 \mathrm{E}-07 \\
5.59 \mathrm{E}-07 \\
\end{array}$ & $\begin{array}{r}5.59 \mathrm{E}-08 \\
5.59 \mathrm{E}-07 \\
5.59 \mathrm{E}-06 \\
\end{array}$ & $\begin{array}{r}5.59 \mathrm{E}-07 \\
5.59 \mathrm{E}-07 \\
5.59 \mathrm{E}-07 \\
\end{array}$ & $\begin{array}{r}5.59 \mathrm{E}-08 \\
5.59 \mathrm{E}-07 \\
5.59 \mathrm{E}-06 \\
\end{array}$ & $\begin{array}{r}5.59 \mathrm{E}-07 \\
5.59 \mathrm{E}-07 \\
5.59 \mathrm{E}-07 \\
\end{array}$ & $\begin{array}{r}5.59 \mathrm{E}-08 \\
5.59 \mathrm{E}-07 \\
5.59 \mathrm{E}-06 \\
\end{array}$ & $\begin{array}{l}1.81 \mathrm{E}-04 \\
1.81 \mathrm{E}-04 \\
1.81 \mathrm{E}-04 \\
\end{array}$ & $\begin{array}{l}1.81 \mathrm{E}-05 \\
1.81 \mathrm{E}-04 \\
1.81 \mathrm{E}-03 \\
\end{array}$ & $\begin{array}{r}6.65 \mathrm{E}-06 \\
6.65 \mathrm{E}-06 \\
6.65 \mathrm{E}-06 \\
\end{array}$ & $\begin{array}{l}6.65 \mathrm{E}-07 \\
6.65 \mathrm{E}-06 \\
6.65 \mathrm{E}-05 \\
\end{array}$ & $\begin{array}{l}1.97 \mathrm{E}-03 \\
1.97 \mathrm{E}-03 \\
1.97 \mathrm{E}-03 \\
\end{array}$ & $\begin{array}{l}1.97 \mathrm{E}-04 \\
1.97 \mathrm{E}-03 \\
1.97 \mathrm{E}-02 \\
\end{array}$ \\
\hline
\end{tabular}

Note A. Concentration of unity ( $1 \mathrm{pCi} / \mathrm{g})$ assigned to disposal concentration, to be scaled to downgradient groundwater concentration at receptor well. The disposal concentration is assumed to be the sorbed concentration, and through the assumption of a linear isotherm and an appropriate range of concentrations of $\mathrm{K}_{\mathrm{d}}$ values, the solute in landfill leachate is calculated.

Note B. See $K_{d}$ discussion in Appendix D. The largest $K_{d}$ values correspond to the less conservative case, the mid-range $K_{d}$ values are the base case, and the smallest $K_{d}$ values are more conservative.

Note C. Conc. at water table $=$ conc. of landfill leachate $* \mathrm{e}^{\wedge}$ (time * decay constant). Time is a 60-year transport time for water in the unsaturated zone.

Note D. Each column of proportions is the result of MT3DMS analysis scaled from a starting recharge flux to the aquifer of unity for each radionuclide of concern (ROC). Each adjacent column of concentrations is the concentration at the water table multiplied by the proportion 
TABLE E.2 Calculations Relating Disposal Concentration of Unity, Appropriate Range of In-Landfill $K_{d}$ Values, Leachate Concentration Reaching Water Table, Downgradient Proportion of Leachate Recharge, and Concentration in Groundwater for 100-m (328-ft) Downgradient Receptor and 5-m (16-ft) Thick Unsaturated Zone

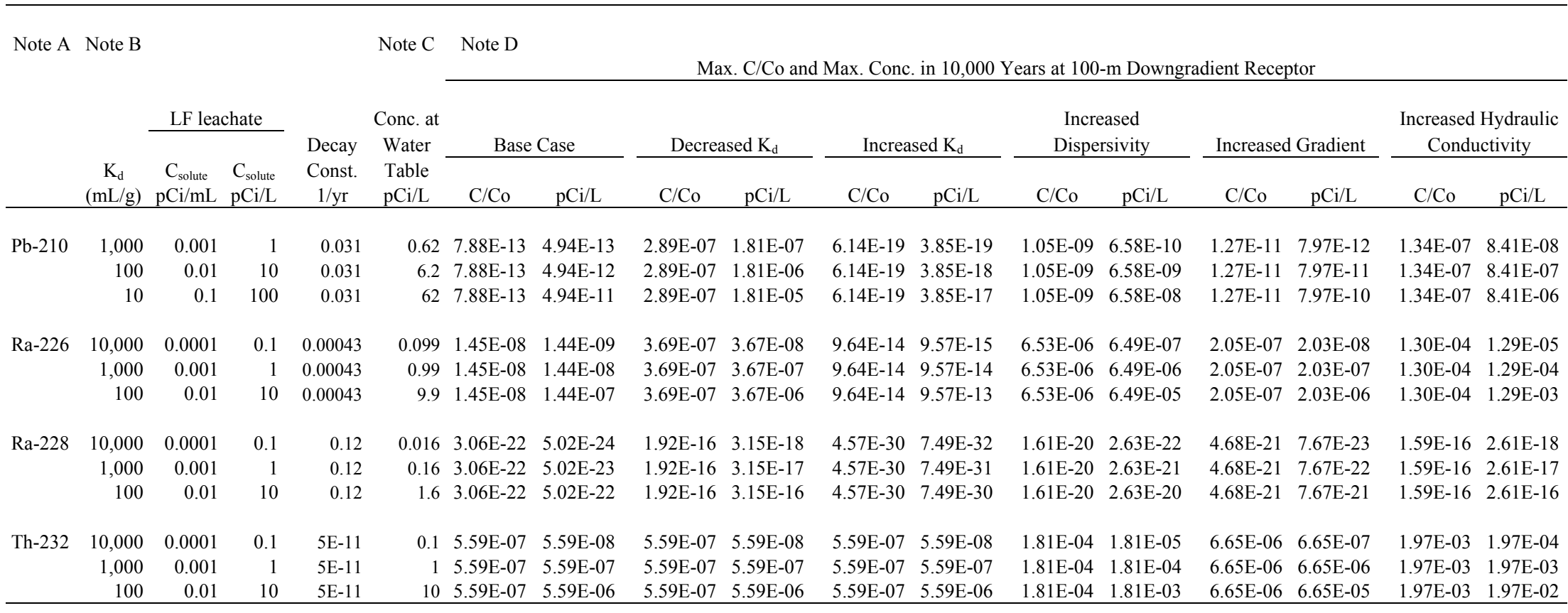

Note A. Concentration of unity $(1 \mathrm{pCi} / \mathrm{g})$ assigned to disposal concentration, to be scaled to downgradient groundwater concentration at receptor well. The disposal concentration is assumed to be the sorbed concentration, and through the assumption of a linear isotherm and an appropriate range of concentrations of $\mathrm{K}_{\mathrm{d}}$ values, the solute in landfill leachate is calculated.

Note B. See $K_{d}$ discussion in Appendix D. The largest $K_{d}$ values correspond to the less conservative case, the mid-range $K_{d}$ values are the base case, and the smallest $K_{d}$ values are more conservative.

Note C. Conc. at water table $=$ conc. of landfill leachate $* \mathrm{e}^{\wedge}($ time $*$ decay constant). Time is a 15 -year transport time for water in the unsaturated zone.

Note D. Each column of proportions is the result of MT3DMS analysis scaled from a starting recharge flux to the aquifer of unity for each ROC. Each adjacent column of concentrations is the concentration at the water table multiplied by the proportion. 
TABLE E.3 Calculations Relating Disposal Concentration of Unity, Appropriate Range of In-Landfill $K_{d}$ Values, Leachate Concentration Reaching Water Table, Downgradient Proportion of Leachate Recharge, and Concentration in Groundwater for 300-m (984-ft) Downgradient Receptor and 20-m (66-ft) Thick Unsaturated Zone

\begin{tabular}{|c|c|c|c|c|c|c|c|c|c|c|c|c|c|c|c|c|c|}
\hline \multirow[t]{3}{*}{ Note A } & \multirow{3}{*}{$\begin{array}{c}\text { Note B } \\
\\
\mathrm{K}_{\mathrm{d}} \\
(\mathrm{mL} / \mathrm{g}) \\
\end{array}$} & & & \multirow{3}{*}{$\begin{array}{c}\text { Decay } \\
\text { Const. } \\
1 / \mathrm{yr}\end{array}$} & \multirow{3}{*}{$\begin{array}{c}\text { Note C } \\
\text { Conc. at } \\
\text { Water } \\
\text { Table } \\
\text { pCi } / \mathrm{L} \\
\end{array}$} & \multicolumn{12}{|c|}{ n 10,000 years at $300-\mathrm{m}$ Downgradient Receptor } \\
\hline & & \multicolumn{2}{|c|}{ LF Leachate } & & & \multicolumn{2}{|c|}{ Base Case } & \multicolumn{2}{|c|}{ Decreased $K_{d}$} & \multicolumn{2}{|c|}{ Increased $\mathrm{K}_{\mathrm{d}}$} & \multicolumn{2}{|c|}{$\begin{array}{c}\text { Increased } \\
\text { Dispersivity }\end{array}$} & \multicolumn{2}{|c|}{ Increased Gradient } & \multicolumn{2}{|c|}{$\begin{array}{l}\text { Increased Hydraulic } \\
\text { Conductivity }\end{array}$} \\
\hline & & $\begin{array}{l}\mathrm{C}_{\text {solute }} \\
\mathrm{pCi} / \mathrm{mL}\end{array}$ & $\begin{array}{l}\mathrm{C}_{\text {solute }} \\
\mathrm{pCi} / \mathrm{L}\end{array}$ & & & $\mathrm{C} / \mathrm{Co}$ & $\mathrm{pCi} / \mathrm{L}$ & $\mathrm{C} / \mathrm{Co}$ & $\mathrm{pCi} / \mathrm{L}$ & $\mathrm{C} / \mathrm{Co}$ & $\mathrm{pCi} / \mathrm{L}$ & $\mathrm{C} / \mathrm{Co}$ & $\mathrm{pCi} / \mathrm{L}$ & $\mathrm{C} / \mathrm{Co}$ & $\mathrm{pCi} / \mathrm{L}$ & $\mathrm{C} / \mathrm{Co}$ & $\mathrm{pCi} / \mathrm{L}$ \\
\hline \multirow[t]{3}{*}{$\mathrm{Pb}-210$} & 1,000 & 0.001 & 1 & 0.031 & 0.15 & 3.47E-32 & $5.33 \mathrm{E}-33$ & $5.26 \mathrm{E}-17$ & $8.08 \mathrm{E}-18$ & $0.00 \mathrm{E}+00$ & $0.00 \mathrm{E}+00$ & $2.92 \mathrm{E}-22$ & 4.49E-23 & $3.09 \mathrm{E}-28$ & $4.75 \mathrm{E}-29$ & $1.96 \mathrm{E}-15$ & $3.00 \mathrm{E}-16$ \\
\hline & 100 & 0.01 & 10 & 0.031 & 1.5 & $3.47 \mathrm{E}-32$ & $5.33 \mathrm{E}-32$ & $5.26 \mathrm{E}-17$ & $8.08 \mathrm{E}-17$ & $0.00 \mathrm{E}+00$ & $0.00 \mathrm{E}+00$ & $2.92 \mathrm{E}-22$ & 4.49E-22 & $3.09 \mathrm{E}-28$ & $4.75 \mathrm{E}-28$ & $1.96 \mathrm{E}-15$ & $3.00 \mathrm{E}-15$ \\
\hline & 10 & 0.1 & 100 & 0.031 & 15 & $3.47 \mathrm{E}-32$ & $5.33 \mathrm{E}-31$ & $5.26 \mathrm{E}-17$ & $8.08 \mathrm{E}-16$ & $0.00 \mathrm{E}+00$ & $0.00 \mathrm{E}+00$ & $2.92 \mathrm{E}-22$ & 4.49E-21 & $3.09 \mathrm{E}-28$ & $4.75 \mathrm{E}-27$ & $1.96 \mathrm{E}-15$ & $3.00 \mathrm{E}-14$ \\
\hline \multirow[t]{3}{*}{ Ra-226 } & 10,000 & 0.0001 & 0.1 & 0.00043 & 0.097 & $3.53 \mathrm{E}-25$ & $3.44 \mathrm{E}-26$ & $3.64 \mathrm{E}-23$ & $3.54 \mathrm{E}-24$ & $5.66 \mathrm{E}-35$ & $5.52 \mathrm{E}-36$ & $1.01 \mathrm{E}-13$ & $9.80 \mathrm{E}-15$ & $2.60 \mathrm{E}-20$ & $2.54 \mathrm{E}-21$ & 2.09E-08 & 2.04E-09 \\
\hline & 1,000 & 0.001 & 1 & 0.00043 & 0.97 & $3.53 \mathrm{E}-25$ & $3.44 \mathrm{E}-25$ & $3.64 \mathrm{E}-23$ & $3.54 \mathrm{E}-23$ & $5.66 \mathrm{E}-35$ & $5.52 \mathrm{E}-35$ & $1.01 \mathrm{E}-13$ & $9.80 \mathrm{E}-14$ & $2.60 \mathrm{E}-20$ & $2.54 \mathrm{E}-20$ & $2.09 \mathrm{E}-08$ & 2.04E-08 \\
\hline & 100 & 0.01 & 10 & 0.00043 & 9.7 & $3.53 \mathrm{E}-25$ & $3.44 \mathrm{E}-24$ & $3.64 \mathrm{E}-23$ & $3.54 \mathrm{E}-22$ & $5.66 \mathrm{E}-35$ & $5.52 \mathrm{E}-34$ & $1.01 \mathrm{E}-13$ & $9.80 \mathrm{E}-13$ & $2.60 \mathrm{E}-20$ & $2.54 \mathrm{E}-19$ & $2.09 \mathrm{E}-08$ & $2.04 \mathrm{E}-07$ \\
\hline \multirow[t]{3}{*}{ Ra-228 } & 10,000 & 0.0001 & 0.1 & 0.12 & 7.2E-05 & $0.00 \mathrm{E}+00$ & $0.0 \mathrm{E}+00$ & $0.00 \mathrm{E}+00$ & $0.00 \mathrm{E}+00$ & $0.00 \mathrm{E}+00$ & $0.00 \mathrm{E}+00$ & $0.0 \mathrm{E}+00$ & $0.00 \mathrm{E}+00$ & $0.00 \mathrm{E}+00$ & $0.00 \mathrm{E}+00$ & $0.00 \mathrm{E}+00$ & $0.00 \mathrm{E}+00$ \\
\hline & 1,000 & 0.001 & 1 & 0.12 & 0.00072 & $0.00 \mathrm{E}+00$ & $0.0 \mathrm{E}+00$ & $0.00 \mathrm{E}+00$ & $0.00 \mathrm{E}+00$ & $0.00 \mathrm{E}+00$ & $0.00 \mathrm{E}+00$ & $0.0 \mathrm{E}+00$ & $0.00 \mathrm{E}+00$ & $0.00 \mathrm{E}+00$ & $0.00 \mathrm{E}+00$ & $0.00 \mathrm{E}+00$ & $0.00 \mathrm{E}+00$ \\
\hline & 100 & 0.01 & 10 & 0.12 & 0.0072 & $0.00 \mathrm{E}+00$ & $0.0 \mathrm{E}+00$ & $0.00 \mathrm{E}+00$ & $0.00 \mathrm{E}+00$ & $0.00 \mathrm{E}+00$ & $0.00 \mathrm{E}+00$ & $0.0 \mathrm{E}+00$ & $0.00 \mathrm{E}+00$ & $0.00 \mathrm{E}+00$ & $0.00 \mathrm{E}+00$ & $0.00 \mathrm{E}+00$ & $0.00 \mathrm{E}+00$ \\
\hline \multirow[t]{3}{*}{ Th-232 } & 10,000 & 0.0001 & 0.1 & $5 \mathrm{E}-11$ & 0.1 & $6.50 \mathrm{E}-23$ & $6.50 \mathrm{E}-24$ & $6.50 \mathrm{E}-23$ & $6.50 \mathrm{E}-24$ & $6.50 \mathrm{E}-23$ & $6.50 \mathrm{E}-24$ & $3.88 \mathrm{E}-11$ & $3.88 \mathrm{E}-12$ & $2.40 \mathrm{E}-18$ & $2.40 \mathrm{E}-19$ & $9.75 \mathrm{E}-07$ & 9.75E-08 \\
\hline & 1,000 & 0.001 & 1 & $5 \mathrm{E}-11$ & 1 & $6.50 \mathrm{E}-23$ & $6.50 \mathrm{E}-23$ & $6.50 \mathrm{E}-23$ & $6.50 \mathrm{E}-23$ & $6.50 \mathrm{E}-23$ & $6.50 \mathrm{E}-23$ & $3.88 \mathrm{E}-11$ & $3.88 \mathrm{E}-11$ & $2.40 \mathrm{E}-18$ & $2.40 \mathrm{E}-18$ & $9.75 \mathrm{E}-07$ & $9.75 \mathrm{E}-07$ \\
\hline & 100 & 0.01 & 10 & $5 \mathrm{E}-11$ & 10 & $6.50 \mathrm{E}-23$ & $6.50 \mathrm{E}-22$ & $6.50 \mathrm{E}-23$ & $6.50 \mathrm{E}-22$ & $6.50 \mathrm{E}-23$ & $6.50 \mathrm{E}-22$ & $3.88 \mathrm{E}-11$ & $3.88 \mathrm{E}-10$ & $2.40 \mathrm{E}-18$ & $2.40 \mathrm{E}-17$ & $9.75 \mathrm{E}-07$ & $9.75 \mathrm{E}-06$ \\
\hline
\end{tabular}

Note A. Concentration of unity ( $1 \mathrm{pCi} / \mathrm{g})$ assigned to disposal concentration, to be scaled to downgradient groundwater concentration at receptor well. The disposal concentration is assumed to be the sorbed concentration, and through the assumption of a linear isotherm and an appropriate range of concentrations of $\mathrm{K}_{\mathrm{d}}$ values, the solute in landfill leachate is calculated.

Note B. See $K_{d}$ discussion in Appendix D. The largest $K_{d}$ values correspond to the less conservative case, the mid-range $K_{d}$ values are the base case, and the smallest $K_{d}$ values are more conservative.

Note C. Conc. at water table $=$ conc. of landfill leachate $* \mathrm{e}^{\wedge}($ time $*$ decay constant). Time is a 60 -year transport time for water in the unsaturated zone.

Note D. Each column of proportions is the result of MT3DMS analysis scaled from a starting recharge flux to the aquifer of unity for each ROC. Each adjacent column of concentrations is the concentration at the water table multiplied by the proportion. 
TABLE E.4 Calculations Relating Disposal Concentration of Unity, Appropriate Range of In-Landfill $K_{d}$ Values, Leachate Concentration Reaching Water Table, Downgradient Proportion of Leachate Recharge and Concentration in Groundwater for 300-m (984-ft) Downgradient Receptor and 5-m (16-ft) Thick Unsaturated Zone

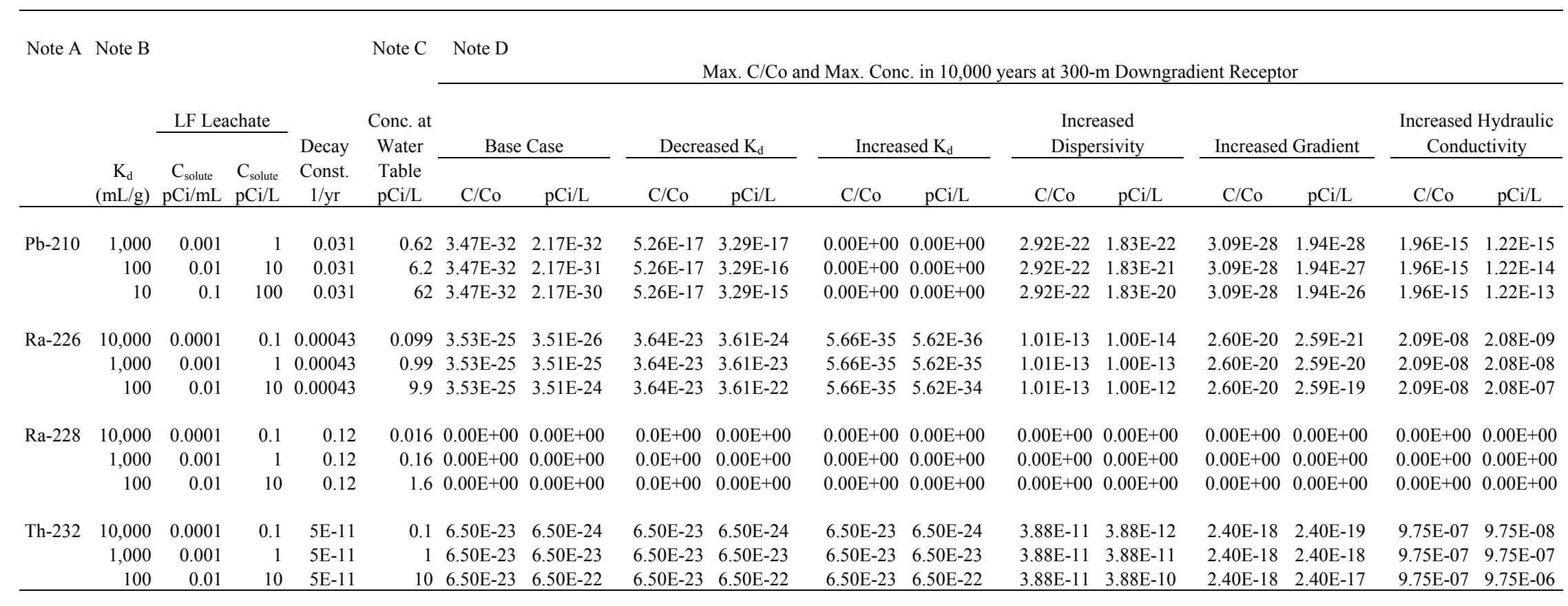

Note A. Concentration of unity $(1 \mathrm{pCi} / \mathrm{g})$ assigned to disposal concentration, to be scaled to downgradient groundwater concentration at receptor well. The disposal concentration is assumed to be the sorbed concentration, and through the assumption of a linear isotherm and an appropriate range of concentrations of $\mathrm{K}_{\mathrm{d}}$ values, the solute in landfill leachate is calculated.

Note B. See $K_{d}$ discussion in Appendix D. The largest $K_{d}$ values correspond to the less conservative case, the mid-range $K_{d}$ values are the base case, and the smallest $K_{d}$ values are more conservative.

Note C. Conc. at water table $=$ conc. of landfill leachate $* \mathrm{e}^{\wedge}($ time $*$ decay constant). Time is a 15 -year transport time for water in the unsaturated zone.

Note D. Each column of proportions is the result of MT3DMS analysis scaled from a starting recharge flux to the aquifer of unity for each ROC. Each adjacent column of concentrations is the concentration at the water table multiplied by the proportion. 

Argonne

Environmental Science Division

Argonne National Laboratory

9700 South Cass Avenue, Bldg. 240

Argonne, IL 60439-4847

www.anl.gov

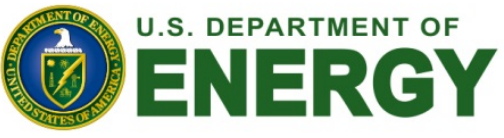

Argonne National Laboratory is a U.S. Department of Energy

laboratory managed by UChicago Argonne, LLC 